\title{
Generalized Hydrogeology and Ground-Water Budget for the C Aquifer, Little Colorado River Basin and Parts of the Verde and Salt River Basins, Arizona and New Mexico
}

Water-Resources Investigations Report 02-4026
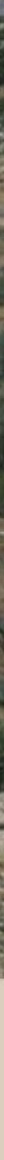


\section{Generalized Hydrogeology and Ground-Water Budget for the C Aquifer, Little Colorado River Basin and Parts of the Verde and Salt River Basins, Arizona and New Mexico}

Water-Resources Investigations Report 02-4026

Prepared in cooperation with the

NATIONAL PARK SERVICE 


\section{U.S. DEPARTMENT OF THE INTERIOR \\ GALE A. NORTON, Secretary}

U.S. GEOLOGICAL SURVEY

Charles G. Groat, Director

The use of firm, trade, and brand names in this report is for identification purposes only and does not constitute endorsement by the U.S. Geological Survey.

For additional information write to:

District Chief

U.S. Geological Survey

Water Resources Division

520 N. Park Aveune, Suite 221

Tucson, AZ 85719-5035
Copies of this report can be purchased from:

U.S. Geological Survey

Information Services

Box 25286

Federal Center

Denver, C0 80225-0046

Information regarding research and data-collection programs of the U.S. Geological Survey is available on the Internet via the World Wide Web. You may connect to the home page for the Arizona District Office using the URL http://az.water.usgs.gov. 


\section{CONTENTS}

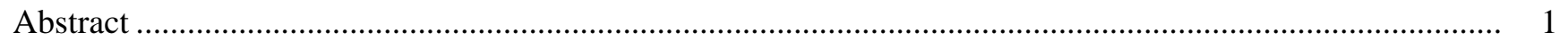

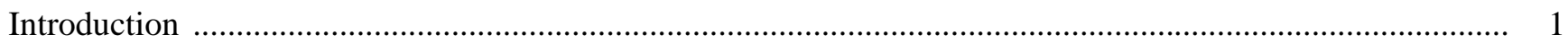

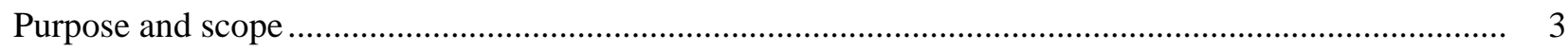

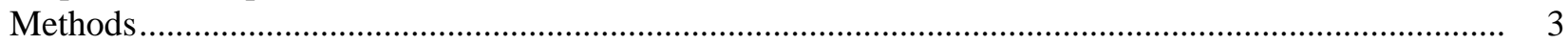

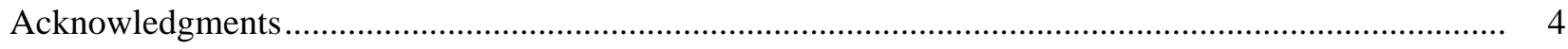

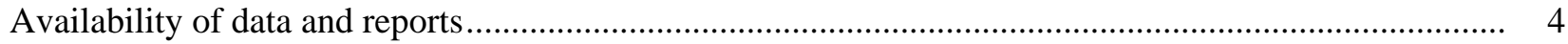

Data

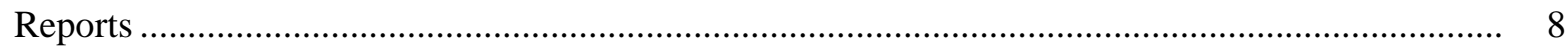

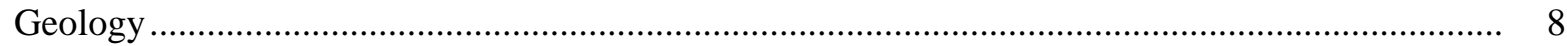

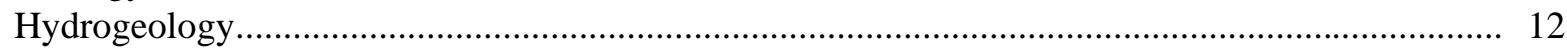

Ground-water models and water budgets..................................................................... 12

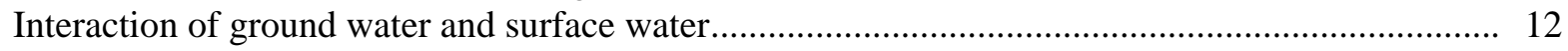

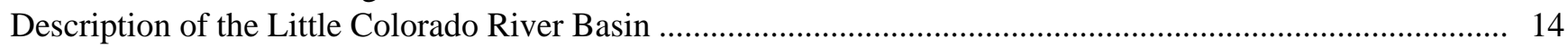

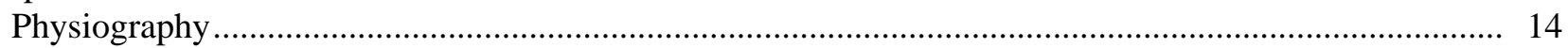

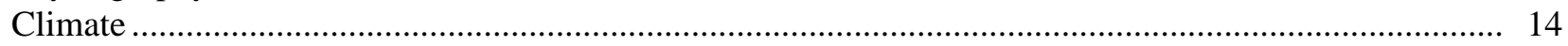

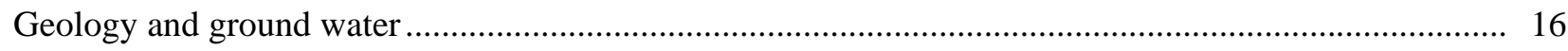

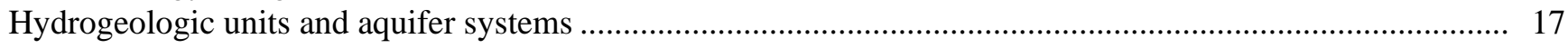

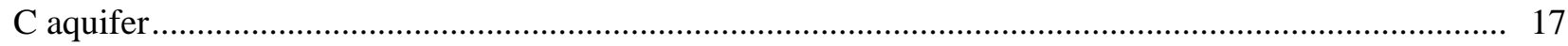

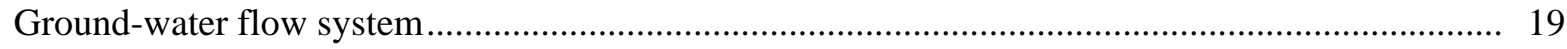

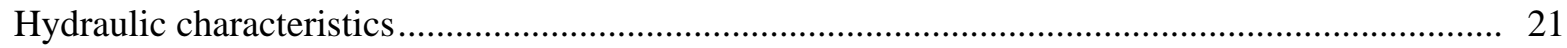

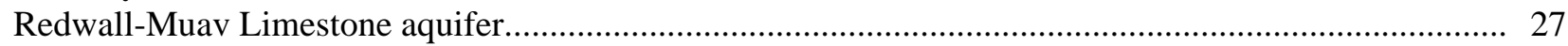

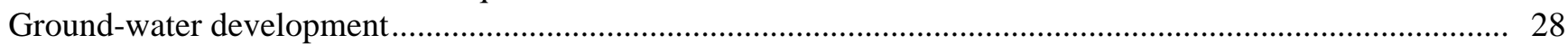

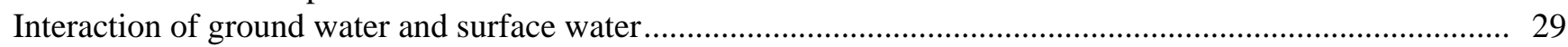

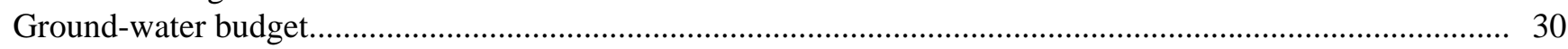

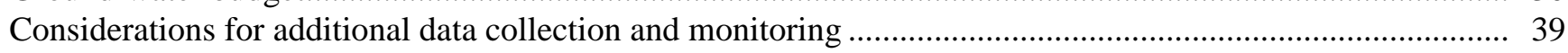

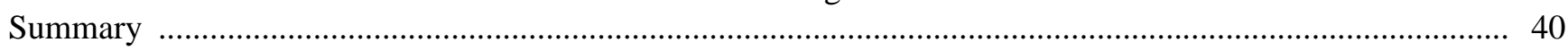

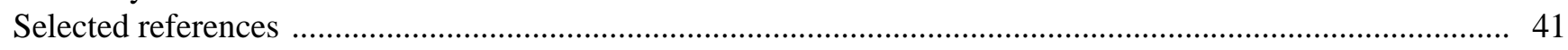

Plate

Stratigraphic correlation of rock units in the Little Colorado River Basin, Arizona and New Mexico In pocket at back of report 


\section{FIGURES}

1-10. Maps showing:

1. Location of study area, physiographic features, and generalized boundary of the $\mathrm{C}$ aquifer, Little Colorado River Basin and parts of the Verde and Salt River Basins, Arizona and New Mexico

2. Distribution of wells that discharge water from the $\mathrm{C}$ aquifer, Little Colorado River Basin and parts of the Verde and Salt River Basins, Arizona and New Mexico

3. Distribution of wells and springs that discharge water from the Redwall-Muav Limestone aquifer, Little Colorado River Basin and parts of the Verde and Salt River Basins, Arizona and New Mexico

3. Distribution of perennial and regulated streams and of springs that discharge water from the $\mathrm{C}$ aquifer, Little Colorado River Basin and parts of the Verde and Salt River Basins, Arizona and New Mexico

5. Locations of streamflow-gaging stations in the Little Colorado River Basin and parts of the Verde and Salt River Basins, Arizona and New Mexico

6. Generalized surface geology of the Little Colorado River Basin, Arizona and New Mexico

7. Precipitation amounts over the Little Colorado river Basin based on the ParameterElevation Regressions on Independent Slope Model (PRISM) and areas where there is a potential for direct recharge through outcrops of the Kaibab Formation or Coconino Sandstone.....

8. Outcrops of rock units that compose the $\mathrm{C}$ aquifer, Little Colorado River Basin and parts of the Verde and Salt River Basins, Arizona and New Mexico

9. Potentiometric contours, direction of ground-water flow, and locations of ground-water divides in the $\mathrm{C}$ aquifer, Little Colorado River Basin and parts of the Verde and Salt River Basins, Arizona and New Mexico

10. Generalized hydrogeologic sections of the Little Colorado River Basin and adjoining areas from

A. The Colorado River to the Verde River 22

B. Near Flagstaff, Arizona, along Interstate 40 to the Arizona-New Mexico State line. 22

11. Schematic representation of the outflow components of the $\mathrm{C}$ aquifer and the interaction of the aquifer with the underlying Redwall-Muav aquifer 


\section{TABLES}

1. Summary of ground-water budget components for the study area from previous investigations

2. Summary of selected well information and aquifer properties for the $\mathrm{C}$ aquifer, Little Colorado River Basin, Arizona.

3. Estimated ground-water withdrawals from the $\mathrm{C}$ aquifer, Arizona and New Mexico, 1976-95

4. Estimated spring discharge as base flow at streamflow-gaging stations of the U.S. Geological Survey in Arizona ...

5. Spring discharge from the $\mathrm{C}$ aquifer and limestone aquifers from various data sources, Little Colorado, Verde, and Salt River Basins, Arizona and New Mexico

6. Summary of spring discharge by basin as base flow, at spring source, or as downward leakage from the $\mathrm{C}$ aquifer, Little Colorado River Basin and parts of the Verde and Salt River Basins, Arizona and New Mexico

7. Summary of annual ground-water budget components for the $\mathrm{C}$ aquifer, Little Colorado River Basin and parts of the Verde and Salt River Basins, Arizona and New Mexico

\section{CONVERSION FACTORS AND VERTICAL DATUM}

\begin{tabular}{rll}
\hline Multiply & By & To obtain \\
inch $(\mathrm{in})$. & 25.4 & millimeter \\
mile $(\mathrm{mi})$ & 1.609 & kilometer \\
square mile $\left(\mathrm{mi}^{2}\right)$ & 2.590 & square kilometer \\
foot per mile $(\mathrm{ft} / \mathrm{mi})$ & 0.1894 & meter per kilometer \\
foot squared per day $(\mathrm{ft} / \mathrm{d})$ & 0.09290 & meter squared per day \\
gallon per $\mathrm{minute}$ & 0.06309 & liter per second \\
gallon per day per foot $(\mathrm{gal} / \mathrm{d}) / \mathrm{ft}$ & 0.2070 & liter per second per meter \\
gallon per day per foot squared $\left.(\mathrm{gal} / \mathrm{d}) / \mathrm{ft}{ }^{2}\right)$ & 0.041 & liter per day per meter squared \\
$\mathrm{acre}$ & 0.4047 & hectare \\
acre-foot $(\mathrm{acre}-\mathrm{ft})$ & 0.001233 & cubic hectometer \\
acre-foot per year $(\mathrm{acre}-\mathrm{ft} / \mathrm{yr})$ & 0.001233 & cubic hectometer per year \\
\hline
\end{tabular}

Temperature in degrees Fahrenheit $\left({ }^{\circ} \mathrm{F}\right)$ may be converted to degrees Celsius $\left({ }^{\circ} \mathrm{C}\right)$ as follows:

$$
{ }^{\circ} \mathrm{C}=\left({ }^{\circ} \mathrm{F}-32\right) / 1.8
$$

\section{VERTICAL DATUM}

Sea level: In this report, "sea level" refers to the National Geodetic Vertical Datum of 1929 (NGVD of 1929)—A geodetic datum derived from a general adjustment of the first-order level nets of both the United States and Canada, formerly called Sea Level Datum of 1929. Altitude, as used in this report, refers to distance above or below sea level. 
WELL (A-19-09)17dcd
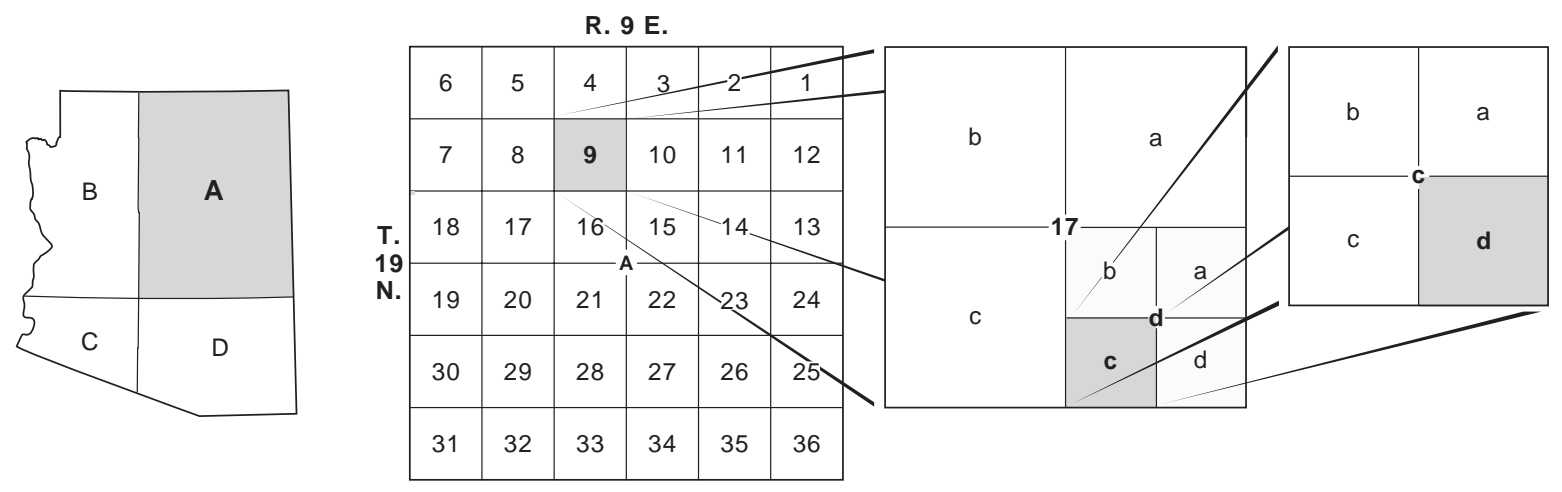

Quadrant A, Township 19 North, Range 9 East, section 17, quarter section $d$, quarter section $c$, quarter section $d$

The well numbers used by the U.S. Geological Survey in Arizona are in accordance with the Bureau of Land Management's system of land subdivision. The land survey in Arizona is based on the Gila and Salt River meridian and base line, which divide the State into four quadrants and are designated by capital letters A, B, C, and D in a counterclockwise direction beginning in the northeast quarter. The first digit of a well number indicates the township, the second the range, and the third the section in which the well is situated. The lowercase letters a, b, c, and d after the section number indicate the well location within the section. The first letter denotes a particular 160 -acre tract, the second the 40 -acre tract and the third the 10 -acre tract. These letters also are assigned in a counterclockwise direction beginning in the northeast quarter. If the location is known within the 10 -acre tract, three lowercase letters are shown in the well number. Where more than one well is within a 10 -acre tract, consecutive numbers beginning with 1 are added as suffixes. In the example shown, well number (A-19-09)17dcd designates the well as being in the SE1/4, SW1/4, SE1/4, section 17, Township 19 North, and Range 9 East.

\section{NEW MEXICO WELL-NUMBERING SYSTEM}

WELL T.16 N. R.16W.17.214
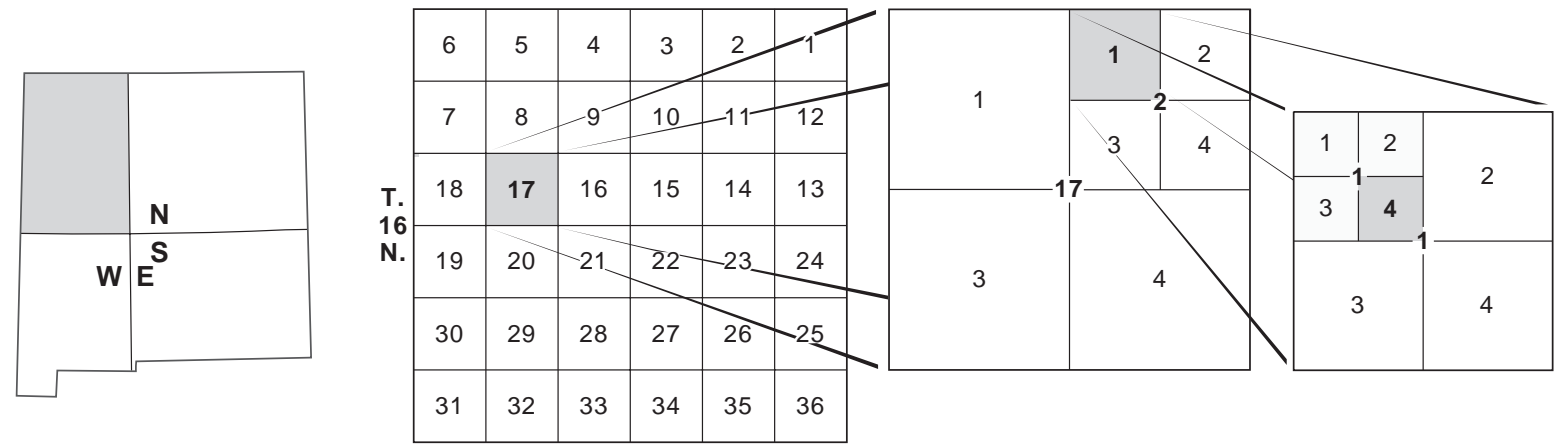

Township 16 North, Range 16 West, section 17,

quarter section 2, quarter section 1, quarter section 1, quarter section 4

In New Mexico, the State identification number locates the well site to the nearest 2.5-acre tract in the land network. The site number is divided into four segments. The first segment denotes the township north or south of the New Mexico Base Line; the second segment denotes the range east or west of the New Mexico Principal Meridian; the third segment denotes the section. The fourth segment, consisting of four digits, denotes the 160-, 40-, 10-, and 2.5-acre tracts, respectively, in which the site is situated. For this purpose, the section is divided into four quarters, numbered 1, 2, 3, and 4, in the normal reading order. for the northwest, northeast, southwest, and southeast quarters, respectively. The first digit of the fourth segment gives the quarter section, which is a tract of 160 acres. Similarly, the quarter section is divided into four 40 -acre tracts numbered in the same manner; the second digit denotes the 40 -acre tract. The 40 -acre tract is divided into four 10-acre tracts; the third digit denotes the 10-acre tract. The 10-acre tract is divided into four 2.5-acre tracts; the fourth digit denotes the 2.5 -acre tract. thus, site T. 16 N., R. 16 W., 17.2114 is in the NE1/4NW1/4NW1/4SE1/4, section 17, Township 16 North, Range 16 West, second 160-acre tract, first 40acre tract, first 10 -acre tract, and fourth 2.5 -acre tract. If the site cannot be located accurately within a 2.5 -acre tract, the fourth digit is absent; if it cannot be located accurately within a 10-acre tract, the third digit is absent; if it cannot be located accurately within a 40-acre tract, the second, third, and fourth digits are absent. If the site cannot be located more closely than a section, the entire fourth segment of the number is omitted (Gallaher and Cary, 1986). 


\section{WELL-NUMBERING SYSTEM, NAVAJO RESERVATION, ARIZONA AND NEW MEXICO}
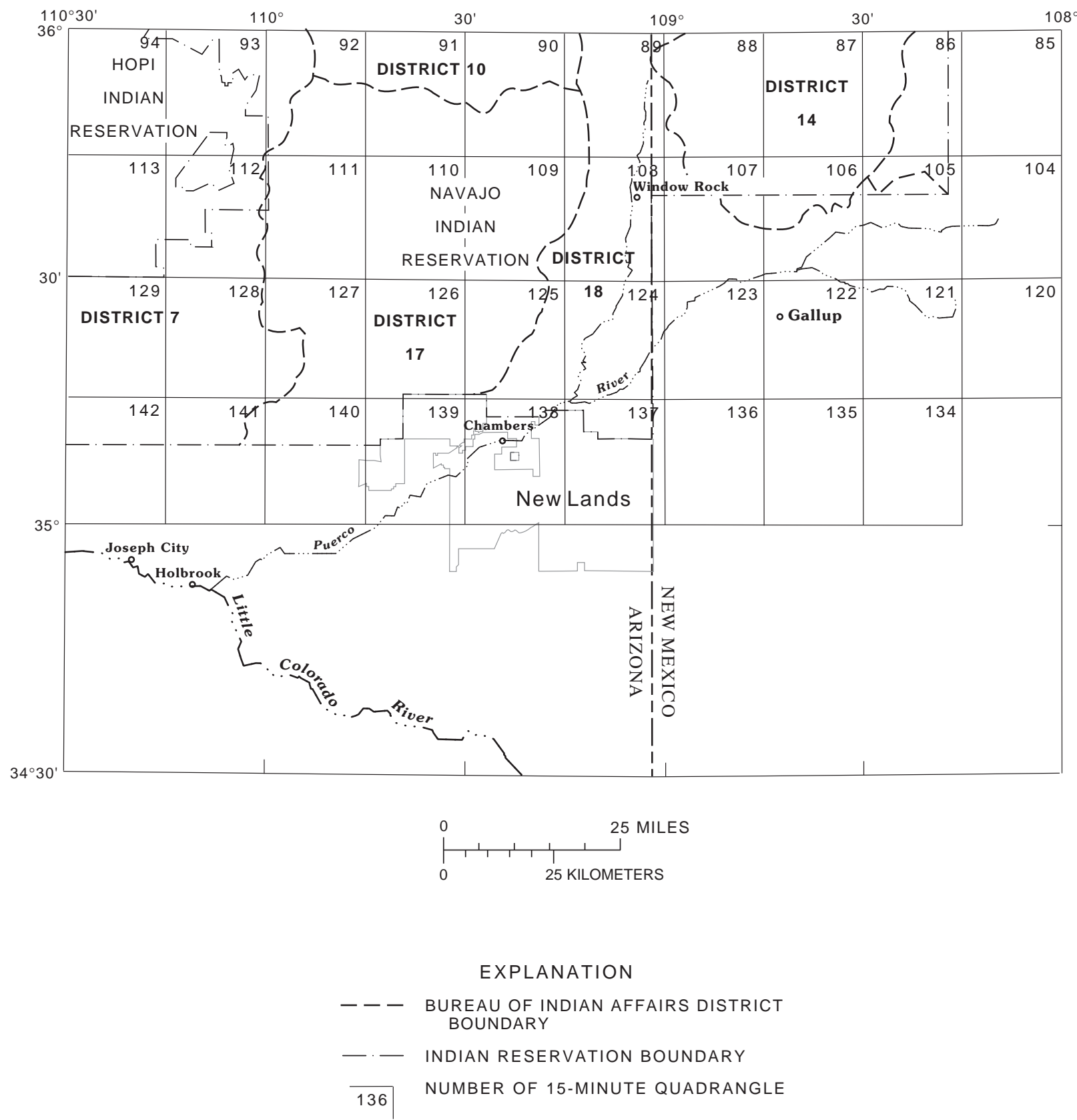

In the Navajo Reservation, where public land surveys have not been made, the local identifier is a filed number that consists of three parts. The first part is formed from the Bureau of Indian Affairs (BIA) district number. The second part is the 15-minute quadrangle number also assigned by the BIA. The third part is the quadrangle location number and indicates the position of a site within a 15-minute quadrangle and consists of two parts. The first part is the distance in miles west of the northeast corner of the quadrangle, and the second part is the distance in miles south of the northeast corner of the quadrangle. The letter A at the end of the quadrangle location number means an approximate location (Wirt and others, 1991). 


\title{
Generalized Hydrogeology and Ground-Water Budget for the C Aquifer, Little Colorado River Basin and Parts of the Verde and Salt River Basins, Arizona and New Mexico
}

\author{
By Robert J. Hart, John J. Ward'1, Donald J. Bills, and Marilyn E. Flynn
}

\section{Abstract}

The $\mathrm{C}$ aquifer underlies the Little Colorado River Basin and parts of the Verde and Salt River Basins and is named for the primary water-bearing rock unit of the aquifer, the Coconino Sandstone. The areal extent of this aquifer is more than 27,000 square miles. More than 1,000 well and spring sites were identified in the U.S. Geological Survey database for the C aquifer in Arizona and New Mexico. The $\mathrm{C}$ aquifer is the most productive aquifer in the Little Colorado River Basin.

The Little Colorado River is the primary surface-water feature in the area, and it has a direct hydraulic connection with the $\mathrm{C}$ aquifer in some areas. Spring discharge as base flow from the $\mathrm{C}$ aquifer occurs predominantly in the lower 13 miles of the Little Colorado River subsequent to downward leakage into the deeper Redwall-Muav Limestone aquifer. Ground-water mounds or divides exist along the southern and northeastern boundaries of the Little Colorado River Basin. The ground-water divides are significant boundaries of the $\mathrm{C}$ aquifer; however, the location and persistence of the divides potentially can be affected by ground-water withdrawals.

Ground-water development in the C aquifer has increased steadily since the 1940s because population growth has produced an increased need for agricultural, industrial, and public water supply. Ground-water pumpage from the $\mathrm{C}$ aquifer during 1995 was about 140,000 acre-feet.

Ground-water budget components for the $\mathrm{C}$ aquifer were evaluated using measured or estimated discharge values. The system was assumed to be in a steady-state condition with respect to natural recharge and discharge, and the stability of discharge from major springs during the past several decades supported the steady-state assumption. Downward leakage to the Redwall-Muav Limestone aquifer is a major discharge component for the ground-water budget. Discharge from the $\mathrm{C}$ aquifer is estimated to be 319,000 acre-feet per year.

\section{INTRODUCTION}

Federal interests in the Little Colorado River Basin are concerned about the affects that ground-water development could have on the surface-water resources in the basin. In 1996, the Department of Justice, the National Park Service (NPS), and the Bureau of Indian Affairs (BIA) requested that the U.S. Geological Survey (USGS) provide the most current information on the $\mathrm{C}$ aquifer in the Little Colorado River Basin in
Arizona and New Mexico (fig. 1). Other stakeholders in the Little Colorado River Basin participated in a technical study group to help identify water resource concerns for the basin. The technical study group consisted of representatives from the Navajo Nation, Hopi Tribe, Zuni Tribe, White Mountain Apache Tribe, Salt River Project, BIA, U.S. Fish and Wildlife Service, Office of Surface Mining, Bureau of Land Management, Hydro Geo Chem, Inc., and NPS. 


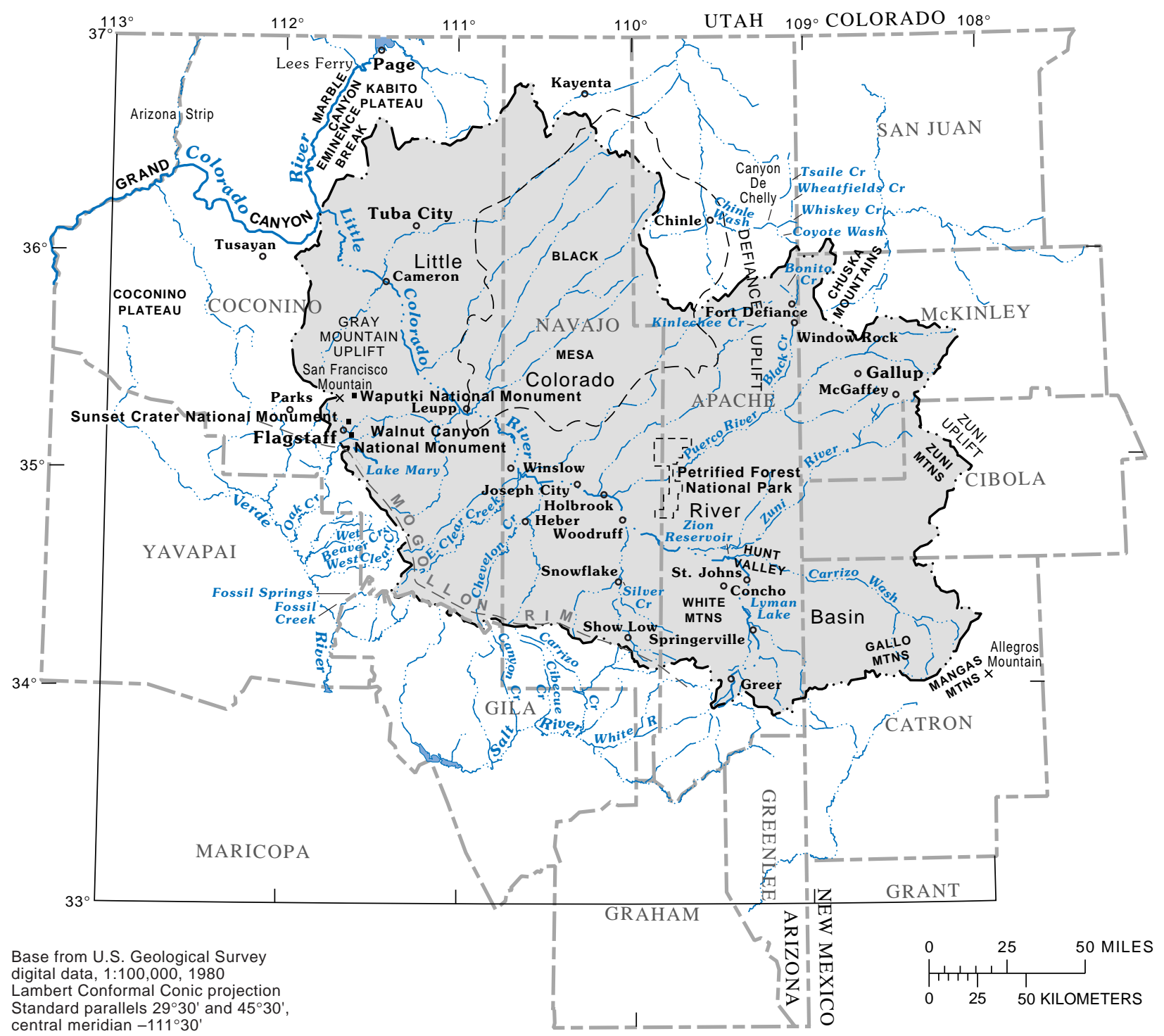

Standard parallels $29^{\circ} 30^{\prime}$ and $45^{\circ} 30^{\prime}$,

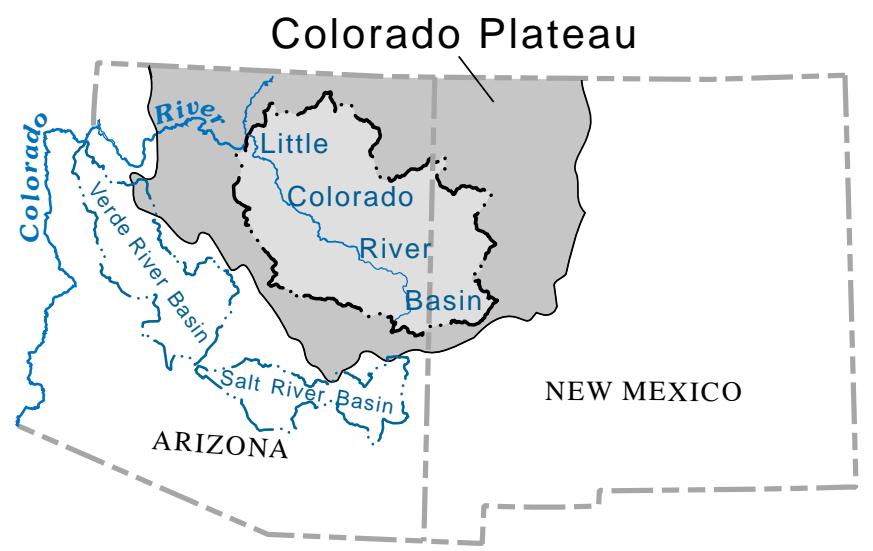

Figure 1. Location of study area, physiographic features, and generalized boundary of the $\mathrm{C}$ aquifer, Little Colorado River Basin and parts of the Verde and Salt River Basins, Arizona and New Mexico. 
The technical study group participants formulated 10 primary objectives. These objectives were to (1) acquire available ground-water literature and data, (2) assemble available data on the hydraulic properties of aquifers, (3) estimate leakage from the $\mathrm{N}$ aquifer to the $\mathrm{C}$ aquifer, (4) define the boundaries of the $\mathrm{C}$ aquifer, (5) define the hydraulic connection between the $\mathrm{C}$ aquifer and underlying rock units, (6) define known discharge points and estimate discharge rates, (7) delineate probable recharge areas and estimate recharge rates, (8) define and map the potentiometric surface of the $C$ aquifer, (9) identify major water users of $\mathrm{C}$ aquifer water and quantify water depletions, and (10) critique and review available water-budget estimates. Because of the lack of available data or information, not all 10 objectives were successfully met.

The $\mathrm{C}$ aquifer is a multiple-aquifer system that encompasses several lithologic formations (Cooley and others, 1969). The Coconino Sandstone is the principal lithologic unit of the $\mathrm{C}$ aquifer. Other important waterbearing rock units of the $\mathrm{C}$ aquifer include the Kaibab Formation and the Upper Supai Formation. The aquifer underlies the entire surface-water drainage of the Little Colorado River and is the most extensive and productive aquifer in the basin. Interest in development and management of water resources and adjudication of water rights in the basin have increased the need for managers to better understand the interaction of ground water and surface water in the basin. The USGS, other Federal agencies, State and local governments, and consulting firms have studied the hydrology of the basin. For this study, the USGS, in cooperation with the NPS, compiled and evaluated available hydrologic data. The compilation and evaluation of information included (1) a summary of hydrologic data and reports, (2) a description of the hydrogeologic units, (3) a description of the interaction of ground water and surface water, (4) an estimated ground-water budget for the $\mathrm{C}$ aquifer, and (5) an identification of gaps in hydrologic data and data needed to better define the $\mathrm{C}$ aquifer system. For clarity in this report, all place names may be assumed to be in Arizona unless otherwise noted.

\section{Purpose and Scope}

The purpose of this report is to describe the availability of hydrologic data, the hydrogeology, and the ground-water budget for the $\mathrm{C}$ aquifer in the Little
Colorado River Basin of Arizona and New Mexico and parts of the Verde and Salt River Basins in Arizona. The Redwall and Muav Limestones that underlie the $\mathrm{C}$ aquifer also are discussed in this report. The groundwater budget analysis includes these limestone units because they are connected hydraulically to the $\mathrm{C}$ aquifer. The USGS databases provided historical and current information that was used to quantify or estimate various ground-water budget components for the study area. Some data were provided by other agencies.

The scope of the report includes discussions of the hydrogeology, structural controls, aquifers, groundwater movement and development, interaction of ground water and surface water, and ground-water budget components for the defined boundary of the $\mathrm{C}$ aquifer. The boundary of the study area is defined by surface and structural geology, the elevation of the top of the $\mathrm{C}$ aquifer, and the potentiometric surface of the $\mathrm{C}$ aquifer. The boundary of the $\mathrm{C}$ aquifer is poorly known to the north and east of the Little Colorado River Basin. The report also describes the methods used to evaluate water-budget data; identifies areas of data deficiencies; and describes future data-collection, analysis, and monitoring that could be used to provide a better understanding of the $\mathrm{C}$ aquifer in the Little Colorado River Basin.

\section{Methods}

Data availability was determined by inventorying the databases managed by the USGS. Data from other agencies also were obtained and compared with data in USGS databases. Reports relating to the hydrology and geology of the Little Colorado River Basin were inventoried using electronic searches or by acquiring publications from existing collections.

Ground-water budget components for the predevelopment period, which is considered to be the period prior to the 1940 s, were evaluated on the basis of available data and past investigations of the study area. Some of the outflow components of the ground-water budget were quantified to the extent possible on the basis of available data and historical field investigations. New data were not collected for this study. 


\section{Acknowledgments}

Mike Foley, Navajo Water Resources Department, provided well information. Bill Hansen, NPS, provided various hydrologic reports. E.M. Clark, Geodetic Research, provided spring-location data for the Fort Apache Indian Reservation. Ron Morgan and Nat Nutongla, Hopi Water Resources Department; John Cawley and John Sorrell, BIA; Steve Parsons, Office of Surface Mining; Jim Renthal, Bureau of Land Management; Kirk Bemis, Zuni Tribe; Dave Roberts and Craig Sommers, Salt River Project; Mike Foley, Navajo Nation; and Bill Hansen and Dan McGlolthlin, NPS, provided input at several Little Colorado River Basin study-group meetings. Dan McGolthlin and Bill Hansen, NPS; and Mike Foley, Navajo Nation, participated on the technical study group. Stan Leake and Anita Rowlands, USGS, provided insight to ground-water modeling and compiled historical publications on the Little Colorado River Basin, respectively.

\section{Availability of Data and Reports}

\section{Data}

The USGS, the Navajo Nation, and other government agencies have compiled and maintained databases for the Little Colorado River Basin. As part of this study, data were retrieved from the surfacewater, ground-water, and water-quality databases of the USGS and from the ground-water database of the Arizona Department of Water Resources (ADWR). Data on oil and gas wells that have been drilled in the study area were obtained from the Arizona Geological Survey. Data are sparse for some areas of the basin and abundant for other areas. For example, groundwater data are sparse for the $\mathrm{C}$ aquifer where the aquifer is not tapped for water supply, such as in the Black Mesa area of the Navajo and Hopi Indian Reservations. Along the Mogollon slope and valley of the Little Colorado River, however, data are more prevalent because of the proximity of the $\mathrm{C}$ aquifer to the land surface.

Ground-water, well, and spring data are maintained in the USGS Ground-Water Site Inventory (GWSI). The GWSI includes records for 892 wells in Arizona and 120 wells in New Mexico with information on the $\mathrm{C}$ aquifer for the Little Colorado River Basin (fig. 2) and areas beyond the Little Colorado River Basin southward to the Verde River, northward to the Colorado River, northeastward toward Monument Valley, and eastward into New Mexico. Records for about 28 sites in Arizona include information on the Redwall-Muav Limestone aquifer that lies beneath the $\mathrm{C}$ aquifer. Only one of these sites was identified as being associated with the Muav Limestone exclusively (fig. 3). Data were not available to determine if wells penetrate the Leadville Limestone in New Mexico. Most well records in the GWSI contain detailed well-construction information and chemical analyses of water. The records indicate that some wells penetrate the $\mathrm{C}$ aquifer and the RedwallMuav Limestone aquifer.

Data in the GWSI indicate that 37 springs discharge water from the $\mathrm{C}$ aquifer (fig. 4). As with the well data, spring data in the GWSI are not current or complete. Several springs that are not listed in the database were identified in the study area from topographic maps, reports, or paper files. The White Mountain Apache Tribe also has identified many springs on the Fort Apache Indian Reservation that are not listed in the GWSI; however, discharge data for these springs could not be obtained for this study. Eleven springs, which discharge a total of about 2,900 acre- $\mathrm{ft} / \mathrm{yr}$ from the $\mathrm{C}$ aquifer, were identified in the part of the basin in New Mexico (Crouch, 1994). The percentage of the total spring discharge that is represented by noninventoried springs in the Little Colorado River Basin is not known but is assumed to be small.

Data in the GWSI indicate that 17 springs discharge water from the Redwall-Muav Limestone aquifer (fig. 3). Several springs issue from the Redwall and Muav Limestones on the northern side of the Colorado River in Marble Canyon. These springs were not included in the data inventory of this study because their source of water may be ground water that flows toward the Colorado River from the Arizona Strip. Discharge data and other information are available for most springs that discharge water from the RedwallMuav Limestone aquifer within the Little Colorado River Basin.

From 1975 to 1990, the USGS monitored six springs in the areas of St. Johns and Concho as part of a program to monitor pumping effects on the $\mathrm{C}$ aquifer. Measurements of spring discharge southward from the Little Colorado River Basin in tributaries of the Verde and Salt Rivers were made by Feth (1954), Feth and Hem (1963), McGavock (1968), and Owen-Joyce and Bell (1983). Numerous unpublished records of spring discharge also exist. 


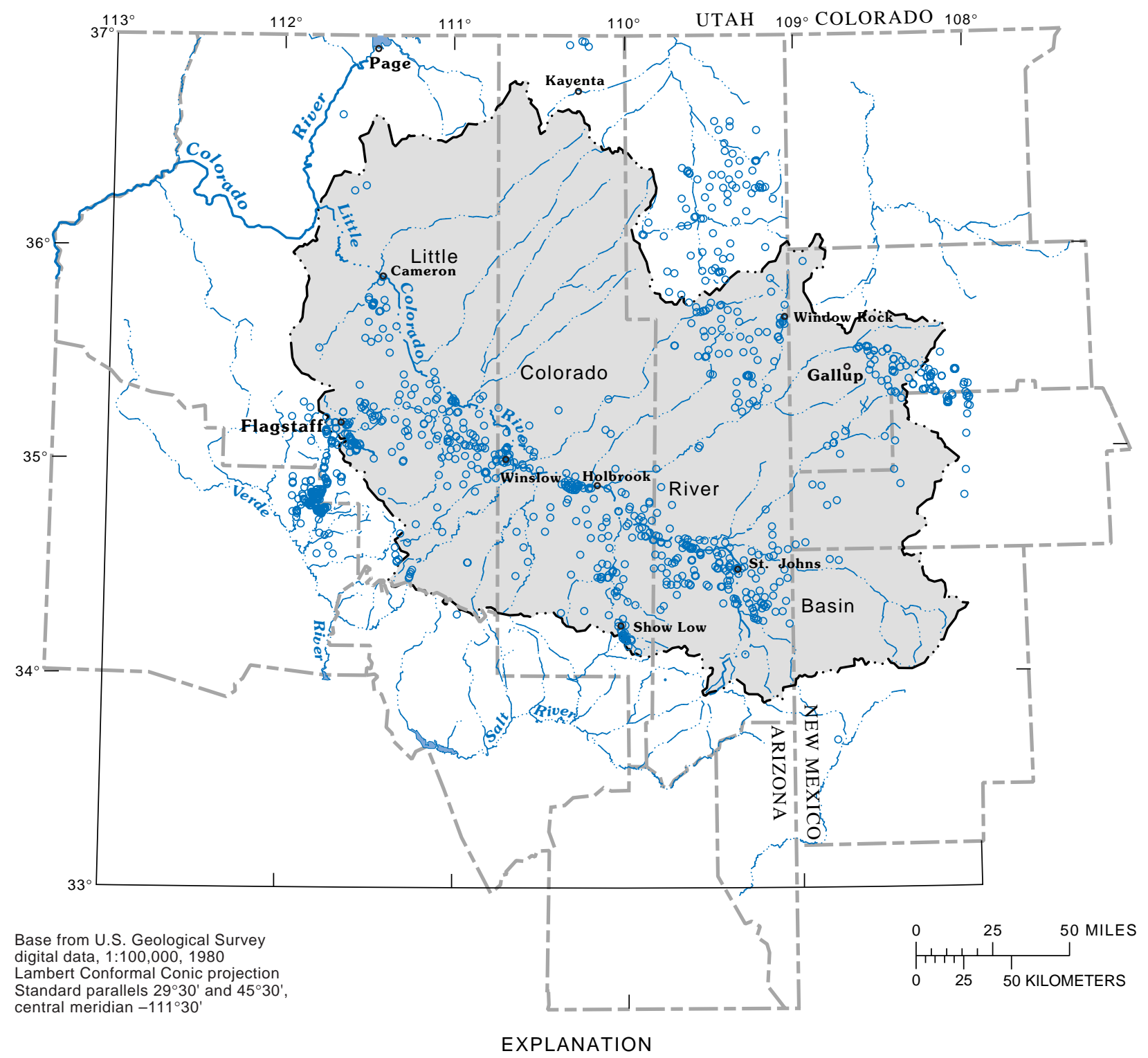

- WELL

Figure 2. Distribution of wells that discharge water from the $C$ aquifer, Little Colorado River Basin and parts of the Verde and Salt River Basins, Arizona and New Mexico. Data from the U.S. Geological Survey Ground-Water Site Inventory. 


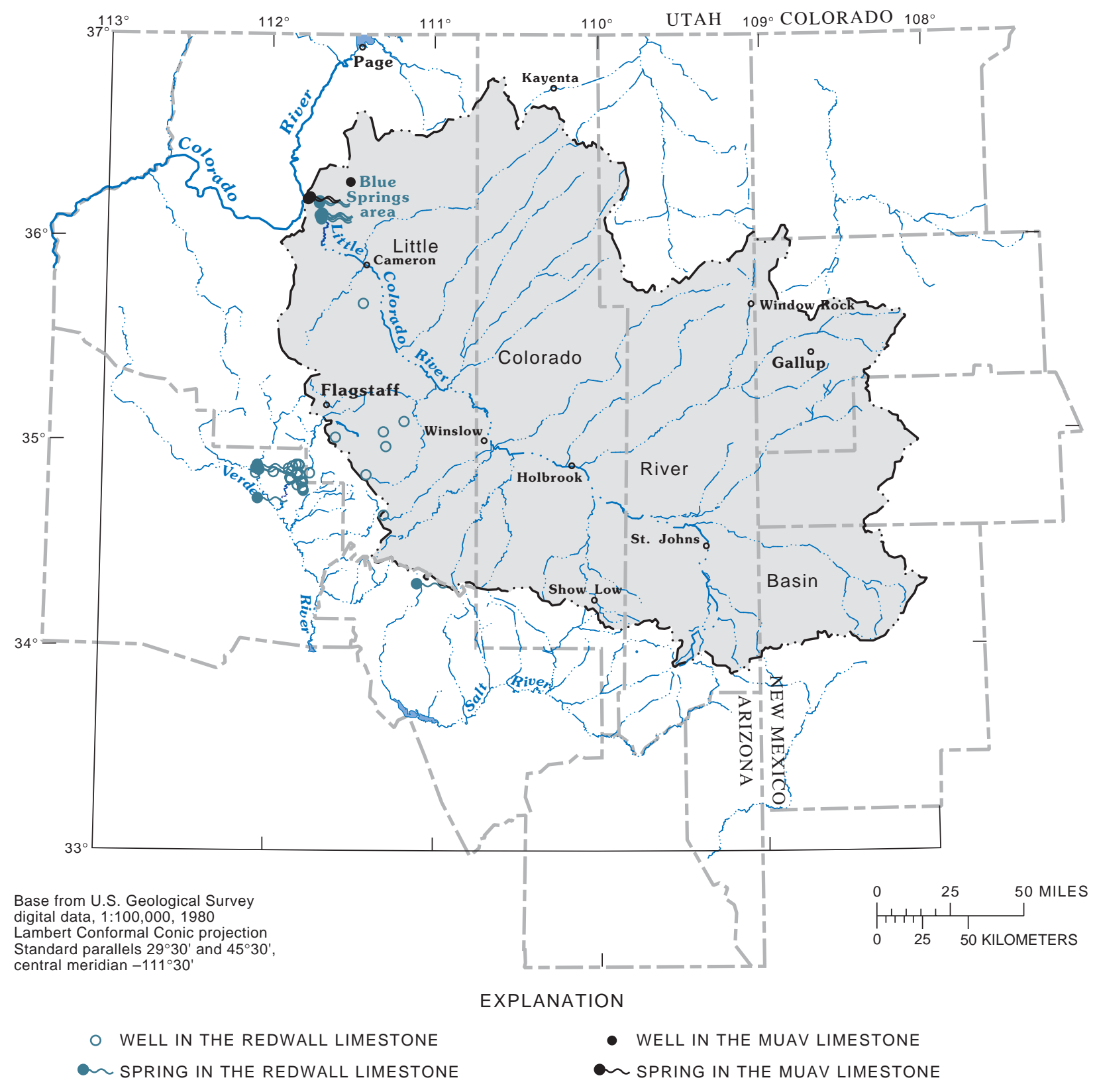

Figure 3. Distribution of wells and springs that discharge water from the Redwall-Muav Limestone aquifer, Little Colorado River Basin and parts of the Verde and Salt River Basins, Arizona and New Mexico. Data from the U.S. Geological Survey Ground-Water Site Inventory. 


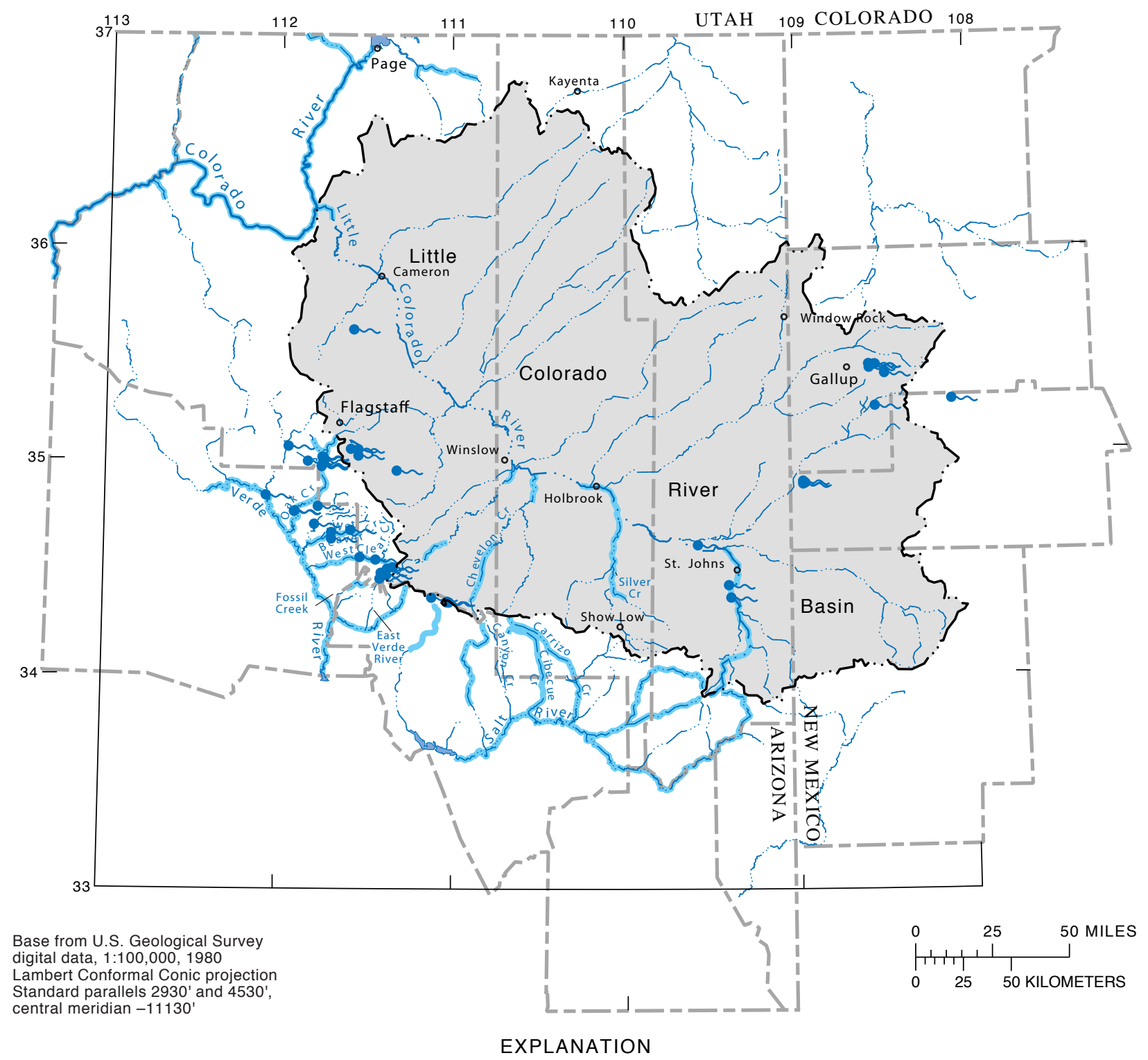

an SPRING IN THE C AQUIFER PERENNIAL OR REGULATED REACH

Figure 4. Distribution of perennial and regulated streams and of springs that discharge water from the $\mathrm{C}$ aquifer, Little Colorado River Basin and parts of the Verde and Salt River Basins, Arizona and New Mexico. Data from U.S. Geological Survey GroundWater Site Inventory; data on perennial or regulated streams from Brown (1978). 
No spring-discharge data were available for the eastern side of the Little Colorado River Basin in the area of the Defiance Plateau. According to Cooley and others (1969), spring discharge from this area primarily is from the De Chelly Sandstone and from joints in the "Supai Formation." From 1990 to 1993, the USGS monitored spring discharge from the Redwall-Muav Limestone aquifer in the lower $13 \mathrm{mi}$ of the Little Colorado River below Blue Springs. In 1998, the USGS began monitoring selected wells developed in the $\mathrm{C}$ aquifer at national parks and monuments, and at other miscellaneous sites within the Little Colorado River Basin.

As of 1996, the USGS maintains 36 continuousrecord streamflow-gaging stations in the study area (fig. 5) and maintains surface-water data in the Automated Data Processing System (ADAPS). Ten of the gaging stations were used in this study to measure base flow that was then used to determine groundwater discharge. The USGS also maintains records from 44 discontinued streamflow-gaging stations in the study area. Many of the surface-water records also contain water-quality data. Paper files from previous investigations that contained seepage data that were not entered into the databases also were inventoried.

The USGS historically has maintained and published water-use data for ground-water areas in Arizona in cooperation with the ADWR (Murray and Reeves, 1972; Solley and others, 1983, 1988, and 1993). Ground-water use is divided into the following categories: agriculture, drained agricultural lands, public supply (domestic, recreational, and commercial), and industrial use (mining, forestry, and electrical power). Up until about 1995, the USGS obtained pumping records from municipalities, industrial users, and other ground-water users on an annual basis and compiled this information for publication.

Other government agencies monitor ground-water levels, spring discharge, and streamflow in the Little Colorado River Basin. The Salt River Project monitors springs and wells in the area of St. Johns for the Coronado generating plant, and Tucson Electric Power Company and Arizona Public Service monitor groundwater levels at the Springerville generating station and the Cholla powerplant, respectively. The Salt River Project and Tucson Electric Power jointly operate streamflow-gaging stations on the Little Colorado River below Lyman Lake and on Lyman Ditch. The Navajo Nation Department of Water Resources and the Hopi Department of Water Resources maintain records of ground-water and surface-water data within their reservation boundaries. The Indian Health Services maintains well-drilling records for Indian reservations. The BIA collects hydrologic data on Indian trust lands. The city of Flagstaff maintains water-level data for selected city wells.

\section{Reports}

In 1994, the USGS, in cooperation with the city of Flagstaff, began an investigation of the $\mathrm{C}$ aquifer in the area of Flagstaff. This study included extensive structural mapping, geo-physical surveying and mapping, determination of hydraulic properties, and chemical and isotopic analysis of ground water (Bills and others, 2000). The NPS has conducted aquifer tests at wells that penetrate the $\mathrm{C}$ aquifer at Sunset Crater and Wupatki National Monuments (Christensen, 1980) and at Petrified Forest National Park.

The USGS has published a series of reports describing ground-water conditions in Arizona. The most recent report, by Anning and Duet (1994), describes water use for 1987 to 1990 . Other reports reviewed for this study were categorized into the following subjects: (1) geology, (2) hydrogeology, (3) ground-water models and water budgets, and (4) interaction of ground water and surface water. The reports are summarized in the following sections. More than 850 bibliographic references on the Little Colorado River Basin and the $\mathrm{C}$ aquifer were identified and cataloged for this investigation.

\section{Geology}

The Permian system of the Colorado Plateau physiographic province has been investigated extensively for mineral, uranium, and coal prospects and for development of oil, gas, and helium resources. Gregory $(1916,1917)$ compiled the first geologic map of the Little Colorado River region and established names for many of the stratigraphic units in the Colorado Plateau. Much of the current understanding of Permian geology in the Little Colorado River Basin has resulted from the work of McKee $(1938,1951)$, Baars (1962), and Peirce (1964). Blakey (1989) and Blakey and Knepp (1989) helped define formational and nomenclature changes for stratigraphic sections of the Permian rocks in the Kaiparowits and Four Corners regions of Arizona and Utah, and along the Mogollon Rim (Blakey, 1979; Elston and DiPaolo, 1979). 


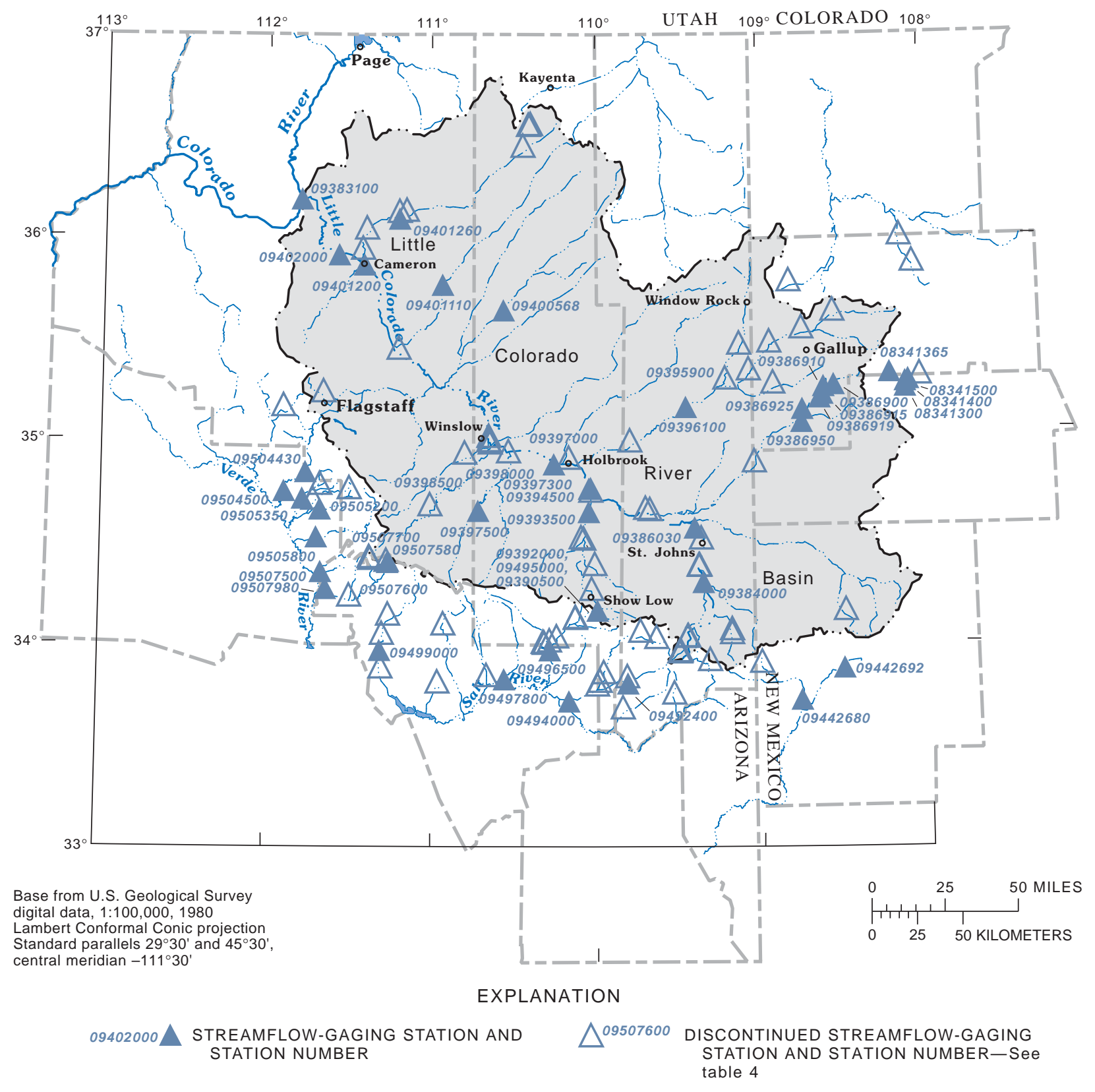

Figure 5. Locations of streamflow-gaging stations in the Little Colorado River Basin and parts of the Verde and Salt River Basins, Arizona and New Mexico.

McKee and Gutschick (1969) and McKee (1982) provided information on the Pennsylvanian and Mississippian geology. Beus $(1989,1990)$ provided stratigraphic sections of Mississippian rocks in Arizona, and Moore and Peirce (1967) studied in detail the transition zone between the Colorado Plateau Province and the Basin and Range Province of the Fort Apache Indian Reservation. An important supplement to these works is Peirce and Scurlock's (1972) compilation of data from oil and gas test wells in Arizona that provided additional definition of the structure of the $\mathrm{C}$ aquifer and the hydraulic-head distribution of ground water in the Redwall Limestone. Reports that show the general surficial geology of the study area include geologic maps of Yavapai County (Wilson and others, 1958), Graham and Greenlee Counties (Wilson and 
of ground water in the Redwall Limestone.

Reports that show the general surficial geology of the study area include geologic maps of Yavapai

County (Wilson and others, 1958), Graham and

Greenlee Counties (Wilson and others, 1958), Gila

County (Wilson and others, 1959), Navajo and

Apache Counties (Wilson and others, 1960), and

Coconino County (Moore and others, 1960).

Studies by O'Sullivan and Beikman (1963),

Hackman and Olson (1977), and Haynes and

Hackman (1978) provided more detailed

information for most of the study area. Reynolds

(1988) published a revised geologic map for the

State of Arizona at a 1:1,000,000 scale.

The geology of New Mexico is detailed on a geologic map at a 1:500,000 scale (Dane and Bachman, 1965) and also on a geologic map for the Gallup $1^{\circ} \times 2^{\circ}$-quadrangle at a 1:250,000 scale (Hackman and Olsen, 1977). Green and Jones (1997) created a digital map of the geology of New Mexico that was reported by Anderson and others (1962). Orr (1987) mapped the geology of the Zuni tribal lands in New Mexico.

Cooley and others (1969) developed detailed geologic maps for the Navajo and Hopi Indian Reservations. Only generalized geology for the Little Colorado River Basin is presented in this report as shown in figure 6 . The generalized geology is based on work by Anderson and others (1962), the U.S. Department of Agriculture (1981), Reynolds (1988), and Schruben and others (1994).

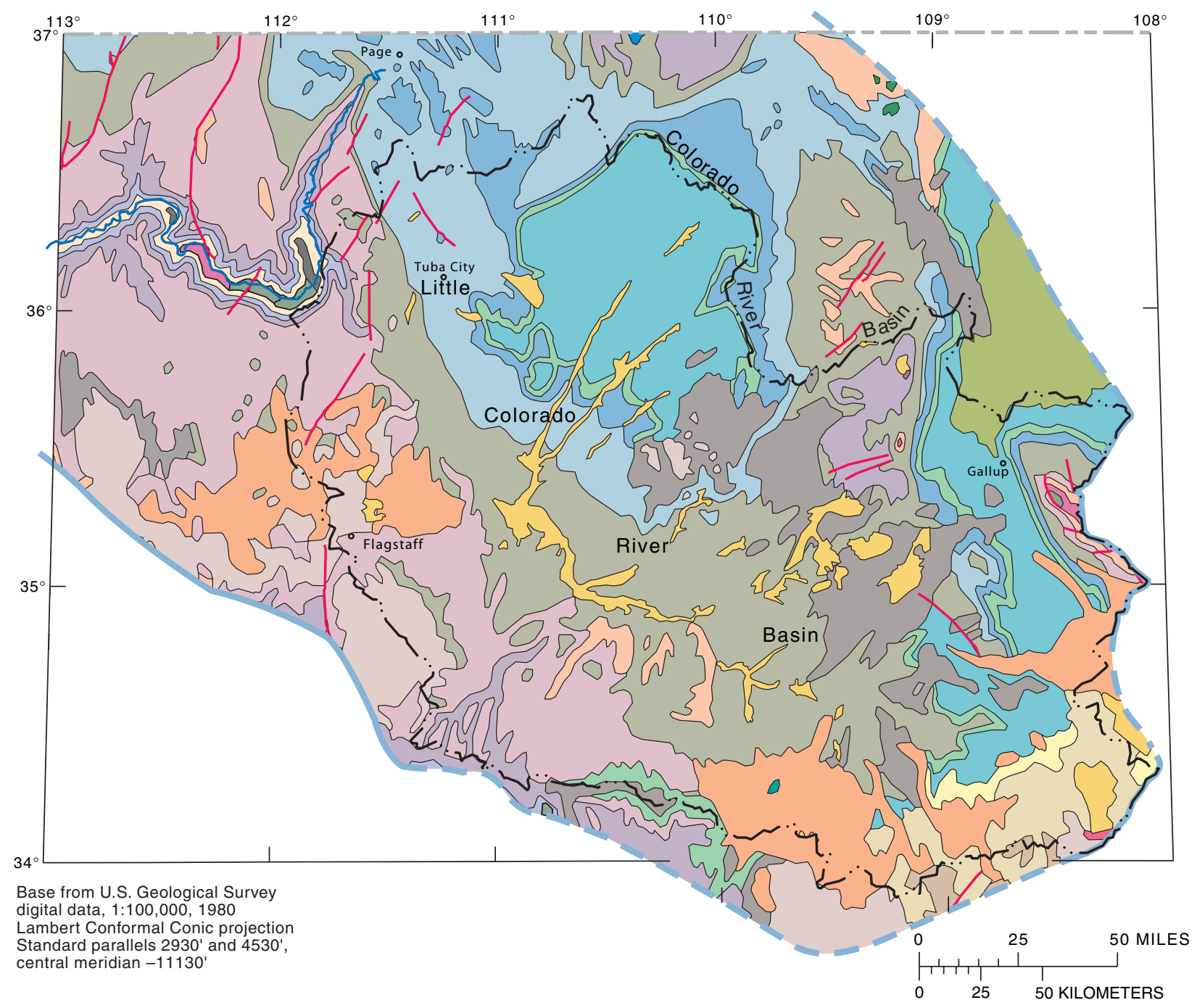

Figure 6. Generalized surface geology of the Little Colorado River Basin, Arizona and New Mexico (modified from Anderson and others, 1962; U.S. Department of Agriculture, 1981; Reynolds, 1988; and Schruben and others, 1994). 


\section{EXPLANATION}

SEDIMENTARY DEPOSITS-Mainly alluvial gravel, sand, and silt, in flood plains, terraces, fans, and pediment cappings, but locally includes dune sand, lake deposits, and landslide masses

VOLCANIC ROCKS-Basaltic flows, agglomerate, tuffs, cinders, calderas, and other geomorphic evidence of youth

VOLCANIC ROCKS-Basaltic flows, agglomerate, tuffs, and cinders. Includes units interfingering with sedimentary deposits, and some possibly older units whose debris is in sedimentary deposits

\section{BACA FORMATION AND CUB MOUNTAIN FORMATION}

DATIL FORMATION-Where undivided, comprising a thick sequence that is for the most part divided into several facies, which are locally defined as separate stratigraphic units as follows:

Andesite and basaltic flows and intrusive rocks

Elastic rocks of volcanic fragments

SEDIMENTARY ROCKS AND ALLUVIAL AND LACUSTRINE DEPOSITS-Mainly conglomerate, sandstone, siltstone, limestone, and tuffaceous beds but locally includes volcanic units ranging from rhyolitic to andesitic in composition. The alluvial and lacustrine deposits include the sedimentary part of the Bidahochi Formation

MESA VERDE GROUP_In Black Mesa area includes Yale Point Sandstone, Wepo Formation, and Toreva Formation. In New Mexico the Gallup Sandstone and the Menefee Formation are included

\section{CREVASSE CANYON FORMATION}

\section{MANCOS SHALE AND DAKOTA SANDSTONE}

SAN RAFAEL GROUP-Includes Cow Springs and Bluff Sandstones, Summerville Formation, Todilto Limestone, and Entrada Sandstone of Late Jurassic age; and Carmel Formation of Late and Middle Jurassic age. In New Mexico, the Zuni Sandstone, part of the Morrison equivalent of Early Jurassic age, is included in the San Rafael Group

TERTIARY

GLEN CANYON GROUP-Includes the Navajo Sandstone, Kayenta Formation, Moenave Formation, and the Wingate Sandstone of Early Jurassic age (Peterson, 1988)

\section{CHINLE AND MOENKOPI FORMATIONS}

\section{KAIBAB FORMATION AND TOROWEAP FORMATION}

SEDIMENTARY ROCKS-Includes De Chelly Sandstone, Coconino Sandstone, and Hermit Shale in Arizona. In New Mexico includes San Andres Limestone, Glorieta Sandstone, and Abo and Yeso Formations

SEDIMENTARY ROCKS-Includes Redwall limestone of Mississippian age, and Temple Butte Limestone of Devonian age

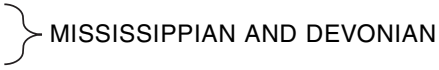

SEDIMENTARY ROCKS-Includes Muav Limestone, Bright Angel Shale, and Tapeats Sandstone

SEDIMENTARY ROCKS-Includes Grand Canyon Supergroup

GRANITIC ROCKS

$\zeta$ CAMBRIAN

$\zeta$ JURASSIC

METAMORPHIC ROCKS

GENERALIZED BOUNDARY OF THE C AQUIFER-Aquifer extends

to the Colorado River in Utah. Dashed where boundary uncertain

FAULT

Figure 6. Continued. 
Hintze (1973) studied rock units that constitute the $\mathrm{C}$ aquifer in Utah (outside this study area). Parker and Roberts (1966) prepared structure and cross-section maps for southern Utah and northern Arizona.

\section{Hydrogeology}

Darton (1910) documented the occurrence of wells and springs in the Little Colorado River Basin mainly along the route of the Santa Fe Railroad. Gregory (1916) made a geographic and hydrographic reconnaissance of parts of Arizona, New Mexico, and Utah. Harrel and Eckel (1939) assessed ground-water resources in the Little Colorado River Basin and inventoried wells and springs in the Holbrook area.

From the 1960s though the 1980s, several countywide and smaller-area ground-water resource assessments were done by the USGS in cooperation with the Arizona Water Commission (now the ADWR). The most comprehensive of these studies described the water resources in the southern part of Coconino County (McGavock and others, 1986), Navajo County (Mann, 1976), and Apache County (Mann and Nemecek, 1983). These reports, however, do not include reservation lands of the Navajo, Hopi, Zuni, or White Mountain Apache Indians. Several water-budget components for the specific study areas are presented in these reports.

Other studies were completed on and adjacent to Indian lands. During the 1950s and 1960s, Cooley and others (1969) studied the hydrogeology of the Navajo and Hopi Indian Reservations. Cooley and others (1969) and Cooley (1976) described the geologic control of ground-water movement in the $\mathrm{C}$ multiple-aquifer system ( $\mathrm{C}$ aquifer) and the major discharge area at Blue Springs in the lower reach of the Little Colorado River. Orr (1987) evaluated water resources on the Zuni Indian Reservation in New Mexico. Hydro Geo Chem (1991) sampled ground water from several wells in the $\mathrm{C}$ aquifer for chemical and isotopic analysis. The USGS, in cooperation with the Hopi Department of Water Resources, began an assessment of water resources on the Hopi Indian Reservation in 1992.

\section{Ground-Water Models and Water Budgets}

Ground-water models have been developed for several parts of the $\mathrm{C}$ aquifer in and adjacent to the Little Colorado River Basin. Mann (1979) developed a model for a 3,400-square-mile area in southern Navajo
County that included a water budget. Skibitzke and Bowen (1983) developed a ground-water model of the $\mathrm{C}$ aquifer near the Salt River Project well fields at the Coronado generating plant near St. Johns. Predictive ground-water models also have been made for the well field at the Springerville powerplant of Tucson Electric Power Company (Errol L. Montgomery and Associates, 1993a). Errol L. Montgomery and Associates (1993b) also determined the composite drawdown effect on the $\mathrm{C}$ aquifer due to ground-water withdrawals for the Springerville and Coronado generating plants. A steady-state model was developed by Hydro Geo Chem (1991) to evaluate ground-water flow near the Navajo and Hopi Indian Reservations. Errol L. Montgomery and Associates (1993b) modeled ground-water yield for the Coconino-Supai aquifer in the Lake Mary well field near Flagstaff.

There are no known comprehensive water budgets available for the $\mathrm{C}$ aquifer for the study area (table 1). A basin-wide water budget for the Little Colorado River was prepared in 1981 by the Soil Conservation Service (U.S. Department of Agriculture, 1981) that includes land-use, climate, streamflow, ground-water resource, and water-budget information. The ADWR (1994a, b) prepared an assessment of the water resources of the basin in Arizona, but no citable water budget was prepared.

Mann (1979) prepared a water budget and mathematical model of the $\mathrm{C}$ aquifer for the southern part of Navajo County. Mann used flow-net analysis to estimate inflow components to the aquifer and available field data to determine outflow components. Mann's results represent inflow and outflow components in 1960 under assumed equilibrium conditions (table 1).

\section{Interaction of Ground Water and Surface Water}

Ground-water discharge from the $\mathrm{C}$ aquifer and its relation to surface-water resources have been measured and documented by several investigators. Feth and Hem (1963) and Twenter and Metzger (1963) measured and compiled records for springs discharging southward to the Salt and Verde River Valleys. Johnson and Sanderson (1968) measured and estimated spring flow and compiled spring data from the Grand Canyon and lower part of the Little Colorado River Basin including Blue Springs between 1952 and 1967. 
Table 1. Summary of ground-water budget components for the study area from previous investigations

[Units are in acre-feet; ET, evapotranspiration; NA, component not available or not determined]

\begin{tabular}{|c|c|c|c|c|c|c|c|c|c|c|c|c|c|c|}
\hline \multirow[b]{2}{*}{ Source } & \multirow[b]{2}{*}{ Area } & \multirow[b]{2}{*}{$\begin{array}{c}\text { Time } \\
\text { period }\end{array}$} & \multirow[b]{2}{*}{$\begin{array}{l}\text { Water } \\
\text { budget }\end{array}$} & \multirow[b]{2}{*}{ Aquifer } & \multicolumn{4}{|c|}{ Inflows } & \multicolumn{6}{|c|}{ Outflows } \\
\hline & & & & & $\begin{array}{l}\text { Base } \\
\text { flow }\end{array}$ & $\begin{array}{l}\text { Infiltration } \\
\text { by } \\
\text { precipitation } \\
\text { or stream- } \\
\text { flow }\end{array}$ & $\begin{array}{l}\text { Vertical } \\
\text { leakage }\end{array}$ & $\begin{array}{l}\text { Under- } \\
\text { flow }\end{array}$ & $\begin{array}{c}\text { Spring } \\
\text { dis- } \\
\text { charge }\end{array}$ & $\begin{array}{l}\text { Leak- } \\
\text { age }\end{array}$ & ET & $\begin{array}{l}\text { Base } \\
\text { flow }\end{array}$ & $\begin{array}{l}\text { Under- } \\
\text { flow }\end{array}$ & $\begin{array}{l}\text { With- } \\
\text { drawals }\end{array}$ \\
\hline $\begin{array}{l}\text { Mann, } \\
1976\end{array}$ & $\begin{array}{l}\text { Southern } \\
\text { Navajo } \\
\text { County }\end{array}$ & 1972 & No & $\begin{array}{l}\text { Coconino } \\
\text { aquifer }\end{array}$ & NA & NA & NA & NA & NA & NA & NA & NA & NA & 24,800 \\
\hline $\begin{array}{l}\text { Mann, } \\
1979\end{array}$ & $\begin{array}{l}\text { Southern } \\
\text { Navajo } \\
\text { County }\end{array}$ & 1960 & $\begin{array}{l}\text { Yes (steady } \\
\text { state simu- } \\
\text { lation) }\end{array}$ & $\begin{array}{l}\text { Coconino } \\
\text { aquifer }\end{array}$ & NA & 11,600 & 11,600 & 41,700 & NA & NA & 1,500 & 8,900 & 82,600 & 12,600 \\
\hline $\begin{array}{l}\text { Mann, } \\
1979\end{array}$ & $\begin{array}{l}\text { Southern } \\
\text { Navajo } \\
\text { County }\end{array}$ & 1960-72 & $\begin{array}{l}\text { Yes } \\
\text { (transient } \\
\text { simulation) }\end{array}$ & $\begin{array}{l}\text { Coconino } \\
\text { aquifer }\end{array}$ & NA & 21,100 & 12,100 & 41,700 & NA & NA & 1,500 & 8,900 & 82,000 & 28,900 \\
\hline $\begin{array}{l}\text { Levings, } \\
1980\end{array}$ & $\begin{array}{l}\text { Sedona } \\
\text { area }\end{array}$ & 1974 & No & $\begin{array}{l}\mathrm{C} \text { aquifer } \\
\text { and } \\
\text { limestone } \\
\text { aquifers }\end{array}$ & NA & NA & NA & NA & $\begin{array}{l}13,000 \\
\text { (sub- } \\
\text { surface } \\
\text { outflow) }\end{array}$ & NA & NA & $\begin{array}{l}37,000 \\
\text { (Oak } \\
\text { Creek) }\end{array}$ & NA & 1,400 \\
\hline $\begin{array}{l}\text { U.S. } \\
\text { Depart- } \\
\text { ment of } \\
\text { Agri- } \\
\text { culture, } \\
1981\end{array}$ & $\begin{array}{l}\text { Little } \\
\text { Colorado } \\
\text { River } \\
\text { Basin }\end{array}$ & 1975 & $\begin{array}{l}\text { Yes; total } \\
\text { water } \\
\text { budget }\end{array}$ & $\begin{array}{l}\text { All } \\
\text { aquifers }\end{array}$ & NA & NA & NA & NA & NA & NA & NA & NA & NA & 140,050 \\
\hline $\begin{array}{l}\text { Owen- } \\
\text { Joyce and } \\
\text { Bell, } 1983\end{array}$ & $\begin{array}{l}\text { Upper } \\
\text { Verde area }\end{array}$ & $1976-80$ & Yes & $\begin{array}{l}\mathrm{C} \text { aquifer } \\
\text { and } \\
\text { limestone } \\
\text { aquifers }\end{array}$ & 16,000 & 169,000 & NA & NA & 31,150 & NA & 35,000 & 80,000 & NA & 8,000 \\
\hline $\begin{array}{l}\text { Mann and } \\
\text { Nemecek, } \\
1983\end{array}$ & $\begin{array}{l}\text { Southern } \\
\text { Apache } \\
\text { County }\end{array}$ & 1975 & No & $\begin{array}{l}\text { Coconino } \\
\text { aquifer }\end{array}$ & NA & NA & NA & NA & NA & NA & NA & NA & NA & 7,700 \\
\hline $\begin{array}{l}\text { McGavock } \\
\text { and others, } \\
1986\end{array}$ & $\begin{array}{l}\text { Southern } \\
\text { Coconino } \\
\text { County }\end{array}$ & 1975 & No & $\begin{array}{l}\text { All } \\
\text { aquifers }\end{array}$ & NA & NA & NA & NA & NA & NA & NA & NA & NA & 5,200 \\
\hline
\end{tabular}

Cooley (1976) evaluated spring flow from pre-

Pennsylvanian rocks in the southwestern part of the Navajo Indian Reservation. Huntoon (1981) described the relation between ground-water flow and geologic structure in Marble Canyon. Huntoon found significant spring discharge into the Colorado River near the Eminence Break area and attributed the primary source of this discharge to the $\mathrm{C}$ aquifer. From about 1990 to 1993, the USGS monitored discharge in the lower $13 \mathrm{mi}$ of the Little Colorado River, and the results of that work are summarized in Rote and others (1997). Loughlin (1983) described hydrogeologic controls on ground water and ground-water circulation for the western part of the Black Mesa area. According to Cooley and others (1976, p. F8), the spring flow from the Redwall and Muav Limestones in the canyon of the Little Colorado River is derived from the Coconino Sandstone, which is the principal unit of the
C aquifer. Cooley and others (1969) described the relation between surface water and ground water along the eastern and western edges of the Little Colorado River Basin.

Several studies have been made on the interaction of ground water and surface water in the Mogollon Rim area. Turner and Feth (1952), Feth (1954), and Feth and Hem (1963) described this interaction and concluded that most of the ground water that leaves the Little Colorado River Basin in this area is discharged from the Redwall Limestone as spring flow. White (1954) provided an analysis of base flow in five perennial streams that flow south toward the Verde and Salt River Basins from the Mogollon Rim region. Bills and Hjalmarson (1990) discussed the interaction between Lyman Lake and the $\mathrm{C}$ aquifer and indicated that the quantity of ground water entering and leaving the lake is related to the water level in the aquifer. 
Baldys and Bayles (1990) described flow characteristics of streams that drain the Fort Apache and San Carlos Indian Reservations. According to Baldys and Bayles (1990), Cibecue and Carrizo Creeks are underlain by the Coconino Sandstone and the Supai Group, and the lower part of the White River drainage is underlain mainly by the Supai Group.

\section{DESCRIPTION OF THE LITTLE COLORADO RIVER BASIN}

\section{Physiography}

The Little Colorado River Basin is in the southern part of the Colorado Plateau physiographic province (Fenneman, 1946) and represents about 27 percent of the plateau area (fig. 1). The Colorado Plateau includes $110,000 \mathrm{mi}^{2}$ of the northeastern part of Arizona, eastern Utah, northwestern New Mexico, and southwestern Colorado. The Little Colorado River originates in the White Mountains of east-central Arizona and flows $356 \mathrm{mi}$ to the Colorado River. The Little Colorado River descends about $18 \mathrm{ft} / \mathrm{mi}$ or $6,300 \mathrm{ft}$ in elevation along its course. Although the river is ephemeral along most of its length, it has perennial reaches at the headwaters in the White Mountains, near Holbrook and Joseph City, and in the lower $13 \mathrm{mi}$ of the river (Brown and others, 1978). The river drains more than $26,950 \mathrm{mi}^{2}$ of northeastern Arizona and northwestern New Mexico, of which $370 \mathrm{mi}^{2}$ is internal drainage. About 80 percent of the drainage is in Arizona $\left(21,700 \mathrm{mi}^{2}\right)$; the remaining drainage is in New Mexico (fig. 1). The Zuni and Puerco Rivers and Carrizo Wash, tributaries of the Little Colorado River, drain the part of the basin that is in New Mexico. The basin is bounded on the south by the Mogollon Rim and White Mountains in Arizona and by the Gallo and Mangas Mountains in New Mexico. The Zuni Mountains and southern Chuska Mountains in New Mexico, and the Defiance Uplift in Arizona, form the eastern boundary. The cuesta of Black Mesa and the Kaibito Plateau form the northern boundary. The basin is bounded on the west by the Grand Canyon and the Coconino Plateau.

Topographic relief is nearly $10,000 \mathrm{ft}$ from an altitude of about 2,700 ft at the mouth of the Little Colorado River to 12,633 ft near Flagstaff. Most mountain ranges and the highest peaks in the basin are on the basin boundaries (fig. 1). Most topography in the basin is developed on nearly horizontal sedimentary rocks and is at or above $5,000 \mathrm{ft}$ in elevation. In the interior of the basin, topographic relief is provided by broad folds, monoclinal flexures, and deeply cut narrow canyons.

\section{Climate}

The climate of the Little Colorado River Basin ranges from arid desert in the lowest valleys to humid subarctic in the highest mountains. Climatic variations are a function largely of land surface altitude, and in some areas, a significant rain-shadow component exists.

Precipitation in the basin has strong seasonal and elevational variability (fig. 7). The primary wet season extends from July through October; July and August are the wettest months. Winter precipitation (November through April) generally is in the form of snow. Average annual snowfall ranges from nearly zero at the lowest altitudes to more than $100 \mathrm{in}$. above $9,000 \mathrm{ft}$. Record wintertime snowfall has exceeded 350 in. (Sellers and others, 1985). Average annual precipitation ranges from 6 to 12 in. in valleys and plateaus, whereas in the forested parts of the mountains, average annual precipitation ranges from 16 to 24 in. The highest mountain ranges in the eastern part of the basin receive significantly less precipitation than similar areas in the western part. Average precipitation exceeds $30 \mathrm{in./yr}$ in some of the higher mountain ranges of the basin; however, these areas represent a small percentage of the total basin (U.S. Department of Agriculture, 1981). The average annual precipitation within the Little Colorado River Basin is approximately 17,000,000 acre-ft. A long-term trend analysis for the southern Colorado Plateau by Hereford and Webb (1992) showed that the number of anomalous dry years increased in this area after 1930, and the number of anomalous wet years decreased. Anomalous wet years were from 1939 to 1941, 1972, and 1980 to 1984.

Temperatures in the study area vary with altitude. For winter months, average daily maximum temperatures are about $28^{\circ} \mathrm{F}$ in the mountainous areas and about $35^{\circ} \mathrm{F}$ in the low desert areas near Cameron. Average daily minimum temperatures during winter range from $6.5^{\circ} \mathrm{F}$ at McGaffey, New Mexico, to $19^{\circ} \mathrm{F}$ at Cameron (U.S. Department of Agriculture, 1981). For summer months, average daily maximum temperatures range from about $64^{\circ} \mathrm{F}$ in the high areas of the White Mountains to more than $90^{\circ} \mathrm{F}$ near Cameron.

Evaporation and transpiration rates are high throughout the basin because of the overall extreme aridity created by the small amount of precipitation and high rate of evapotranspiration (ET). 


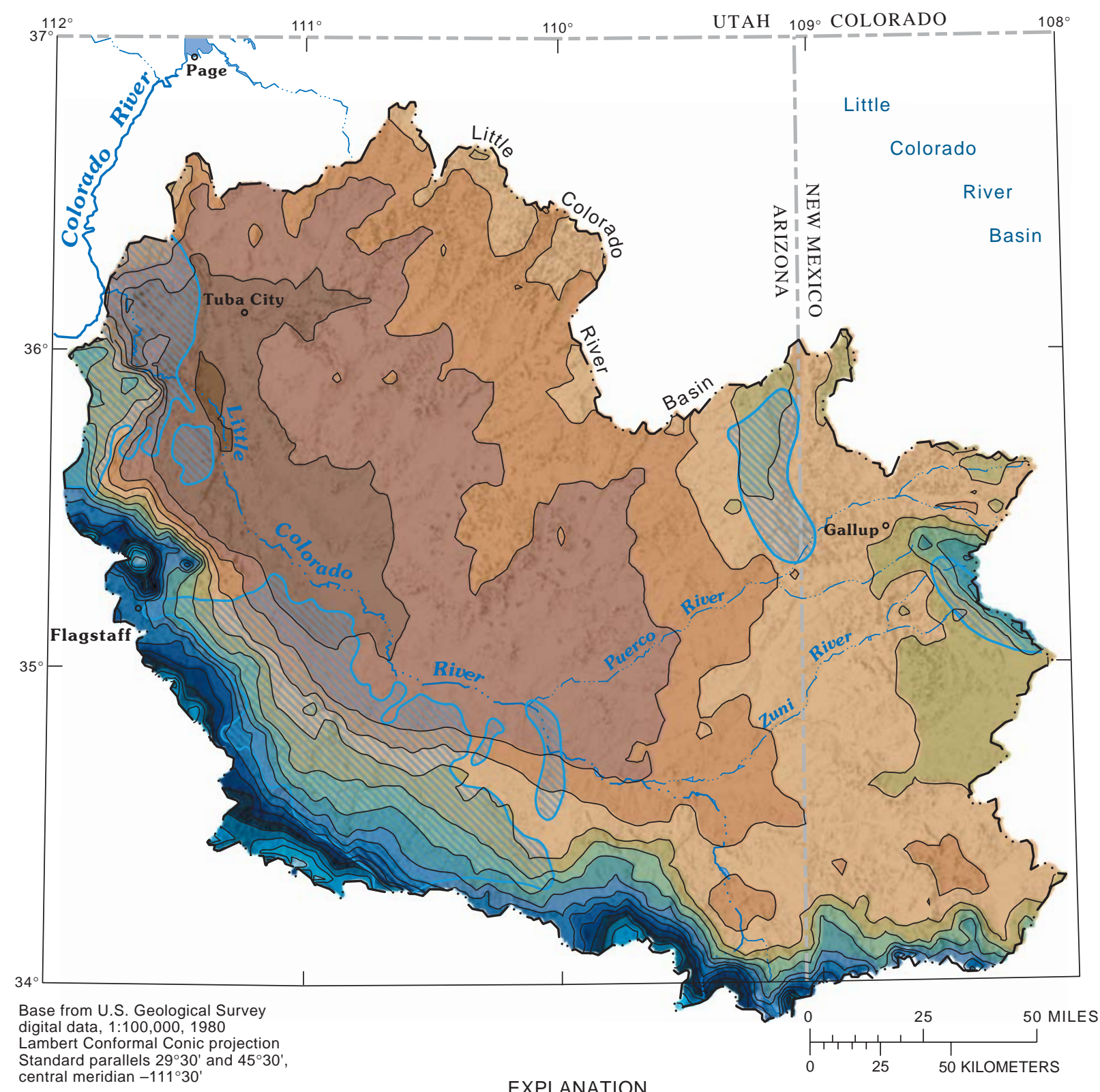

central meridian $-111^{\circ} 30^{\prime}$

MNV AREAS WHERE THERE IS THE POTENTIAL FOR DIRECT
RECHARGE FROM PRECIPIATION ON OUTCROPS OF
THE KAIBAB FORMATION OR COCONINO SANDSTONE

PRECIPITATION, IN INCHES:

\begin{tabular}{|c|c|c|}
\hline Less than 5 & $15-17$ & $27-29$ \\
\hline $5-7$ & $17-19$ & 29-31 \\
\hline $7-9$ & $19-21$ & $31-33$ \\
\hline $9-11$ & $21-23$ & $33-35$ \\
\hline $11-13$ & $23-25$ & $35-37$ \\
\hline $13-15$ & $25-27$ & \\
\hline
\end{tabular}

Figure 7. Precipitation amounts over the Little Colorado river Basin based on the Parameter-Elevation Regressions on Independent Slope Model (PRISM) and areas where there is a potential for direct recharge through outcrops of the Kaibab Formation or Coconino Sandstone. 
Potential evapotranspiration (PET) ranges from less than $30 \mathrm{in} . / \mathrm{yr}$ in the highest mountains to more than $60 \mathrm{in./yr}$ in the lowest deserts (Sellers and Hill, 1974). Precipitation approaches PET rates only in the White Mountains (U.S. Department of Agriculture, 1981).

In summer, ET rates range from about $8 \mathrm{in} . / \mathrm{mo}$ near Greer to more than $16 \mathrm{in} . / \mathrm{mo}$ in the low deserts. In winter, ET rates probably are less than $1 \mathrm{in} . / \mathrm{mo}$ in the mountains and are about $5 \mathrm{in} . / \mathrm{mo}$ in the low deserts (Sellers and Hill, 1974). In winter, precipitation rates probably exceed ET rates only at the higher altitudes in the basin. Direct sublimation of snow at the higher altitudes $(>6,000 \mathrm{ft})$ is a significant atmospheric process that is enhanced by wind and sunshine during the winter.

\section{Geology and Ground Water}

Tectonically, the Colorado Plateau is one of the more stable physiographic provinces in the western United States (Baars, 1962). The Colorado Plateau was subjected to regional uplift, compression, and erosion during the Laramide orogeny (Cretaceous to Eocene) and is in a state of regional extension related to the continuing development of the adjacent and more tectonically active Basin and Range province. The last 5 million years have been characterized by erosion that has resulted in dramatic topographic relief best represented by the Grand Canyon (Shoemaker and others, 1978).

Rock units in the Little Colorado River Basin range in age from Precambrian to Quaternary (pl. 1, fig. 2). The rock units underlying the basin are described here briefly in order from oldest to youngest.

- Precambrian rocks include granite, quartzite, silicified limestone, greenstone, and low-grade phyllite and are exposed in the Zuni and Defiance Uplifts of the Little Colorado River Basin. The Payson granites also are included among the Precambrian rocks and are exposed along the southern margin of the Little Colorado River Basin.

- Cambrian rocks are exposed only in Marble Canyon and include the Tapeats Sandstone, Bright Angel Shale, and Muav Limestone that compose the Tonto Group.

- Devonian rocks include the Temple Butte Limestone in the Grand Canyon area and the Martin Formation in central Arizona (Huddle and Dobrovolny, 1952; Irwin and others, 1971; McGavock and others, 1986).
- Mississippian rocks include the Redwall Limestone in Arizona, which yields large amounts of water to Blue Springs in the lower Little Colorado River (Cooley and others, 1969), and the Leadville Limestone in New Mexico (Irwin and others, 1971).

- Pennsylvanian rocks overlie the Redwall Limestone and consist primarily of the Supai Group and the Naco Formation. The upper part of the Supai Group is Permian in age (McKee, 1982).

- Permian rocks in the Little Colorado River Basin consist of the Hermit Shale, Schnebly Hill Formation, De Chelly Sandstone, Coconino Sandstone, Toroweap Formation, and Kaibab Formation.

- Triassic and Jurassic rocks include the Moenkopi Formation, Chinle Formation, and Glen Canyon Group. The Glen Canyon Group includes the Wingate Sandstone, Moenave Formation, Kayenta Formation, and Navajo Sandstone. Jurassic rocks include the San Rafael Group, Cow Springs Sandstone, and Morrison Formation. The San Rafael Group comprises the Carmel Formation, Entrada Sandstone, Todilto Limestone, Summerville Formation, and Bluff Sandstone (Cooley and others, 1969).

- Cretaceous rocks include the Burro Canyon Formation, Dakota Sandstone, Mancos Shale, and Mesa Verde Group. The Mesa Verde Group consists of the Toreva Formation, Wepo Formation, and Yale Point Sandstone (Cooley and others, 1969).

- Tertiary rocks mainly are volcanic in New Mexico and in Arizona. Tertiary rocks include the Bidahochi Formation, Datil Formation, lava flows, and rim gravels.

- Quaternary rocks include alluvium, basalts, and volcanic rocks. These deposits vary in texture and thickness. Quaternary deposits are in extensive areas of the east-central part of Apache County between the Zuni and Puerco Rivers and north of the Little Colorado River between Holbrook and Winslow (U.S. Department of Agriculture, 1981).

The Little Colorado River Basin is an area of extensive faults, joints, and folds (fig. 6). The folds are monoclines, anticlines, synclines, basins, upwarps, and uplifts. These geologic structures have a significant effect on the occurrence and movement of ground water in the basin, and many of the structural features dominate and define the landscape of the southern Colorado Plateau. The structural features are a result of 
the Laramide orogeny that began in the Early Cretaceous age and was followed by extensional deformation and volcanism in the Late Cenozoic Era (Elston and Young, 1989). The Laramide orogeny resulted in broad regional folds, structural basins, and some of the high-angle, normal and strike-slip faults that are prominent in the basin. Regional extension of the Colorado Plateau has resulted in more high-angle normal and strike-slip faults and prominent joint fractures that are typical of the plateau today. The interior of the basin has undergone much less structural deformation than the basin margins. Much of the upwarping and faulting occurred between the Cretaceous and Tertiary ages (Cooley and others, 1969). The more recent entrenchment of the Colorado and Little Colorado Rivers at the northwestern end of the basin has dewatered substantially the ground-water flow systems of the basin. This dewatering is evident by extensive travertine deposits and hanging solution channels and caves found in Marble Canyon, at the mouth of the Little Colorado River, and at the base of the Redwall Limestone (Huntoon, 1981). Erosion and development of the Mogollon Rim to the south were coincident with the Laramide orogeny (Elston and Young, 1989). Extensive travertine deposits also are found here and are interbedded with sediments of the Verde Formation in the Verde River Valley. The extensional (tension) and compressional (shear) nature of faults also plays a role in the ability of faults to transmit water. In general, extensional faults tend to be more open and can transmit water more easily than compressional faults, which tend to be tighter and, therefore, constrict water movement.

The dominant structure in the Little Colorado River Basin is the large Black Mesa Basin as defined by Cooley and others (1969, p. A18). Structural relief is more than $5,000 \mathrm{ft}$ from the Defiance Uplift to the center of the Black Mesa Basin.

Three large uplifts - the Defiance Uplift (in eastern Arizona), the Zuni Uplift (in western New Mexico), and the Monument Uplift (in Utah outside of the study area) - play a significant role in the movement of ground water as boundaries of flow north and east from the Little Colorado River Basin. Small-scale folding, fracturing, and faulting associated with these uplifts have affected local permeability of the $\mathrm{C}$ aquifer and ground-water flow directions. Small-scale fracturing and faulting occurred in most of the consolidated rocks throughout the basin. Large-scale folding and faulting have created boundaries of flow to the north and west of the basin.

\section{HYDROGEOLOGIC UNITS AND AQUIFER SYSTEMS}

In the Little Colorado River Basin and surrounding area, water-bearing rocks consist primarily of sandstone, limestone, and conglomerate (pl. 1). Multipleaquifer systems yield varying amounts of water in the basin. Lithology, structure, areas of recharge and discharge, and the quantity of inflow and outflow control the movement and storage of ground water.

Several distinct aquifer systems underlie the Little Colorado River Basin and parts of the Verde and Salt River Basins. Three aquifer systems have been identified within the consolidated sedimentary sequences described earlier: (1) the D aquifer (Dakota Sand-stone, Morrison Formation, and Entrada Sandstone), (2) the $\mathrm{N}$ aquifer (Navajo Sandstone, Kayenta Forma-tion, and Wingate Sandstone), and (3) the C aquifer (Kaibab Formation, Coconino Sandstone, Schnebly Hill Formation, and Supai Group; pl. 1). Other aquifer systems include the Pinetop-Lakeside aquifer, the White Mountain aquifer in the Springerville area, the Bidahochi aquifer, and the Redwall-Muav Limestone aquifer. The Redwall-Muav Limestone aquifer is used for water supply in the Coconino Plateau west and south of the Little Colorado River Basin but is largely unexplored within the basin. Alluvial and volcanic deposits that occur locally in many parts of the basin also contain water in places. The $\mathrm{D}$ and $\mathrm{N}$ aquifers in the Black Mesa area are not connected hydraulically to the $\mathrm{C}$ aquifer and, therefore, are not discussed in this report.

\section{Aquifer}

Cooley and others (1969) defined the C multipleaquifer system ( $\mathrm{C}$ aquifer) as the sequence between the top of the Kaibab Formation (and, in some places, the Shinarump Member of the Chinle Formation and the Moenkopi Formation) and the upper part of the Supai Formation. The Coconino Sandstone and its lateral equivalents - the Glorieta Sandstone, De Chelly Sandstone, and the De Chelly Sandstone Member of the Cutler Formation - are the main water-bearing units of the $\mathrm{C}$ aquifer throughout most of the Little Colorado River Basin and are connected hydraulically. Near Flagstaff and eastward toward Heber, the Schnebley Hill Formation is a major part of the $\mathrm{C}$ aquifer (pl. 1). Rocks of the $\mathrm{C}$ aquifer crop out only in the western, southwestern, and northeastern parts of the Little Colorado River Basin (fig. 8). 


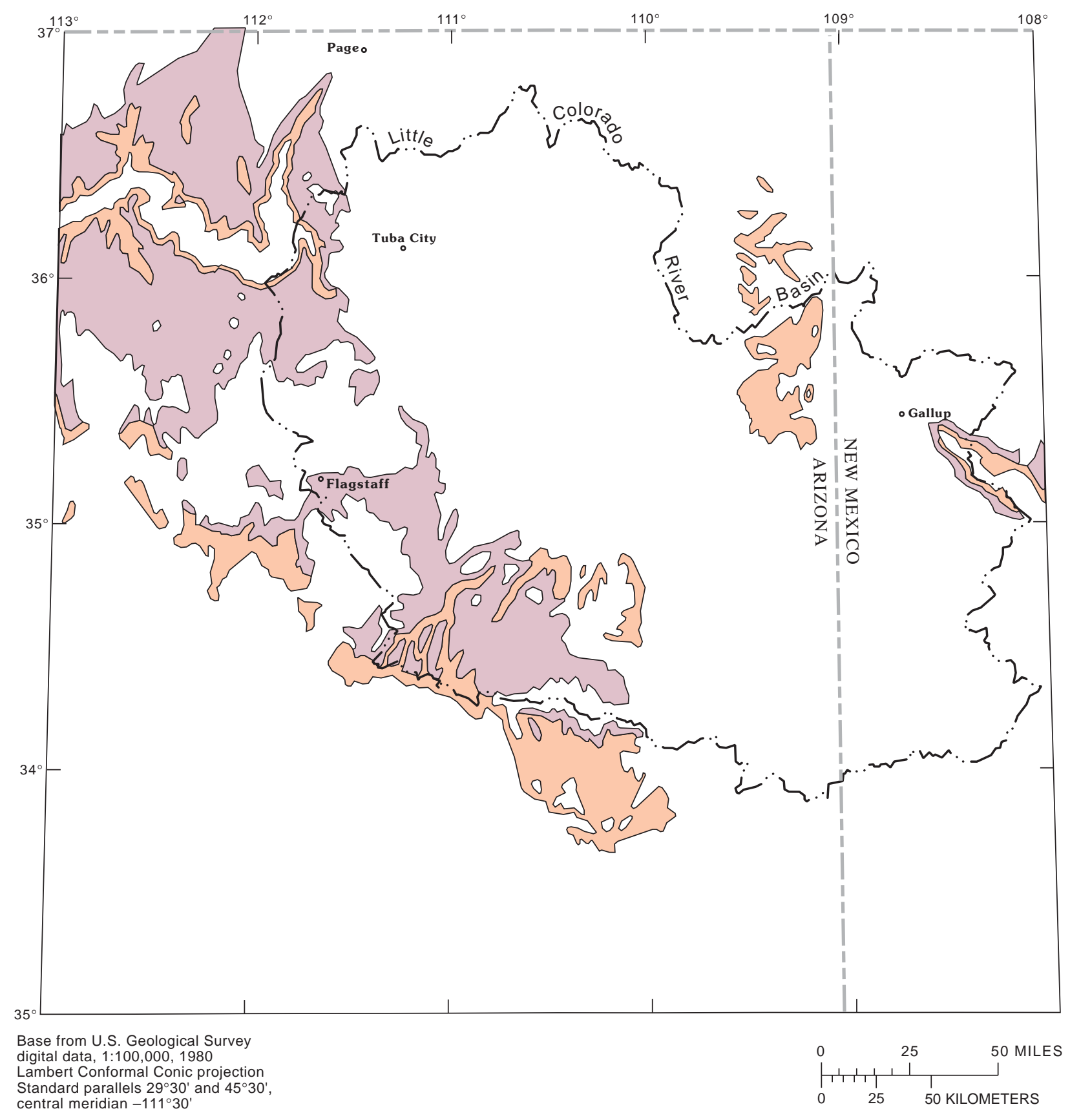

EXPLANATION

KAIBAB FORMATION AND TOROWEAP FORMATION

SEDIMENTARY ROCKS—Includes De Chelly Sandstone, Coconino

Sandstone, and Hermit Shale in Arizona. Includes San Andres

Limestone, Glorieta Sandstone, and Abo and Yeso Formations in

Figure 8. Outcrops of rock units that compose the $C$ aquifer, Little Colorado River Basin and parts of the Verde and Salt River Basins, Arizona and New Mexico (modified from Anderson and others, 1962; U.S. Department of Agriculture, 1981; Reynolds, 1988; and Schruben and others, 1994). 
The Shinarump Member of the Chinle Formation ranges in thickness from 850 to $1,500 \mathrm{ft}$ in the Black Mesa area, and the Kaibab Formation is more than $400 \mathrm{ft}$ thick in the lower Little Colorado River area. The Coconino Sandstone is continuous in the subsurface across the Little Colorado River Basin except in the Defiance Uplift. The formation ranges in thickness from about $60 \mathrm{ft}$ in the northern part of the basin to $900 \mathrm{ft}$ north of Flagstaff. The Glorieta Sandstone is about $300 \mathrm{ft}$ thick near the Zuni Mountains, and the De Chelly Sandstone near the Defiance Uplift ranges in thickness from about 300 to $800 \mathrm{ft}$.

The Supai Group has not been well defined in the basin, but recent work by Blakey and Knepp (1989) has resulted in the reclassification of some rocks assigned to the Supai Group. The thickness of the Supai Group in the basin ranges from $1,100 \mathrm{ft}$ in the Defiance Uplift area to 2,000 ft near the mouth of the Little Colorado River (Irwin and others, 1971). Blakey (1990) reclassified the units of the Supai Group in the southern part of the basin as the Schnebly Hill Formation. The Schnebly Hill Formation varies in thickness from a few feet near Williams and the Defiance Uplift to as much as $1,700 \mathrm{ft}$ in the interior of the basin near Holbrook.

The lateral extent of the $\mathrm{C}$ aquifer generally conforms to the surface-water drainage of the Little Colorado River Basin (fig. 9). The aquifer extends beyond the southern boundary of the basin into the Verde and Salt River Basins, conforming to the outcrops of Pennsylvanian and Permian age rocks (fig. 8), and beyond the north-northwestern boundary of the basin into Utah (fig. 9). In the northeastern part of the study area, the $\mathrm{C}$ aquifer is about 400 to $600 \mathrm{ft}$ thick and thins eastward into New Mexico (Cooley and others, 1969). Paleozoic rocks are relatively unexplored eastward into New Mexico, and ground-water level data are basically nonexistent for areas southeast of Gallup, New Mexico; therefore, the boundary of the $\mathrm{C}$ aquifer is uncertain in these locations. West of the Little Colorado River Basin (fig. 9), the C aquifer is dry except for isolated areas of perched water (McGavock and others, 1986). Ground-water levels in existing wells that discharge water from the $\mathrm{C}$ aquifer range from more than $1,000 \mathrm{ft}$ below land surface near Flagstaff to above land surface near the Little Colorado River roughly between St. Johns and Joseph City.

\section{Ground-Water Flow System}

Most of the ground water in the $\mathrm{C}$ aquifer moves north from a ground-water divide that roughly underlies the Mogollon Rim along the southwestern boundary of the Little Colorado River Basin toward the
Little Colorado River (fig. 9). Regional movement of water primarily is controlled by lithologic characteristics and locally by fractures and joints. Ground water also flows south from the ground-water divide into the Salt and Verde River Basins.

The ground-water divide is an important boundary that is not spatially or temporally fixed, and it can be affected by ground-water withdrawals in the area. The position of the divide is highly uncertain east of Show Low to near the White Mountains because of the paucity of water-level data, and the position is not known from the White Mountains near Springerville, eastward to the Arizona-New Mexico State line.

Another ground-water divide exists along the Defiance Uplift in the northeastern part of the Little Colorado River Basin (fig. 9). Ground water flows north and west from the Defiance Uplift toward and beneath the northward-draining Chinle Wash into the Black Mesa Basin and southwest toward the Puerco River (fig. 9). Ground water also flows eastward from the divide into the San Juan and Rio Grande Basins in New Mexico.

The direction of ground-water flow under the Black Mesa area is uncertain because of the great depth to water and lack of well data. Data from a well drilled in 1965 on the Peabody Coal lease area provide some information about the Black Mesa area (Stetson, 1966). The well was drilled into the Coconino Sandstone to a depth of $5,734 \mathrm{ft}$, and the measured static water level in the well was 4,944 feet above sea level. Movement of ground water in the Black Mesa area is hindered by low aquifer permeability and high salinity (Cooley and others, 1969). From the Black Mesa area, ground water appears to flow south and west toward the Little Colorado River.

Recharge and Discharge.-Recharge to the $\mathrm{C}$ aquifer from precipitation that infiltrates through fractured exposures of Permian and Pennsylvanian rocks occurs primarily along the western and southern edges of the Little Colorado River Basin, coincident with the Mogollon Rim (figs. 7 and 9). Recharge also occurs in the northeastern part of the Little Colorado River Basin on the Defiance Uplift (fig. 7). Less significant recharge occurs through unconsolidated alluvium along the Little Colorado River and some of its tributaries (fig. 4). In Navajo County, recharge occurs along Silver Creek north of Snowflake (Mann, 1976). Water in the $\mathrm{C}$ aquifer in southern Apache County is derived mainly from underflow that enters the area along the ArizonaNew Mexico State line on the east and the boundary of the Navajo Nation on the north (Mann and Nemecek, 1983). Recharge to the $\mathrm{C}$ aquifer also can occur from downward leakage from overlying aquifer units. 


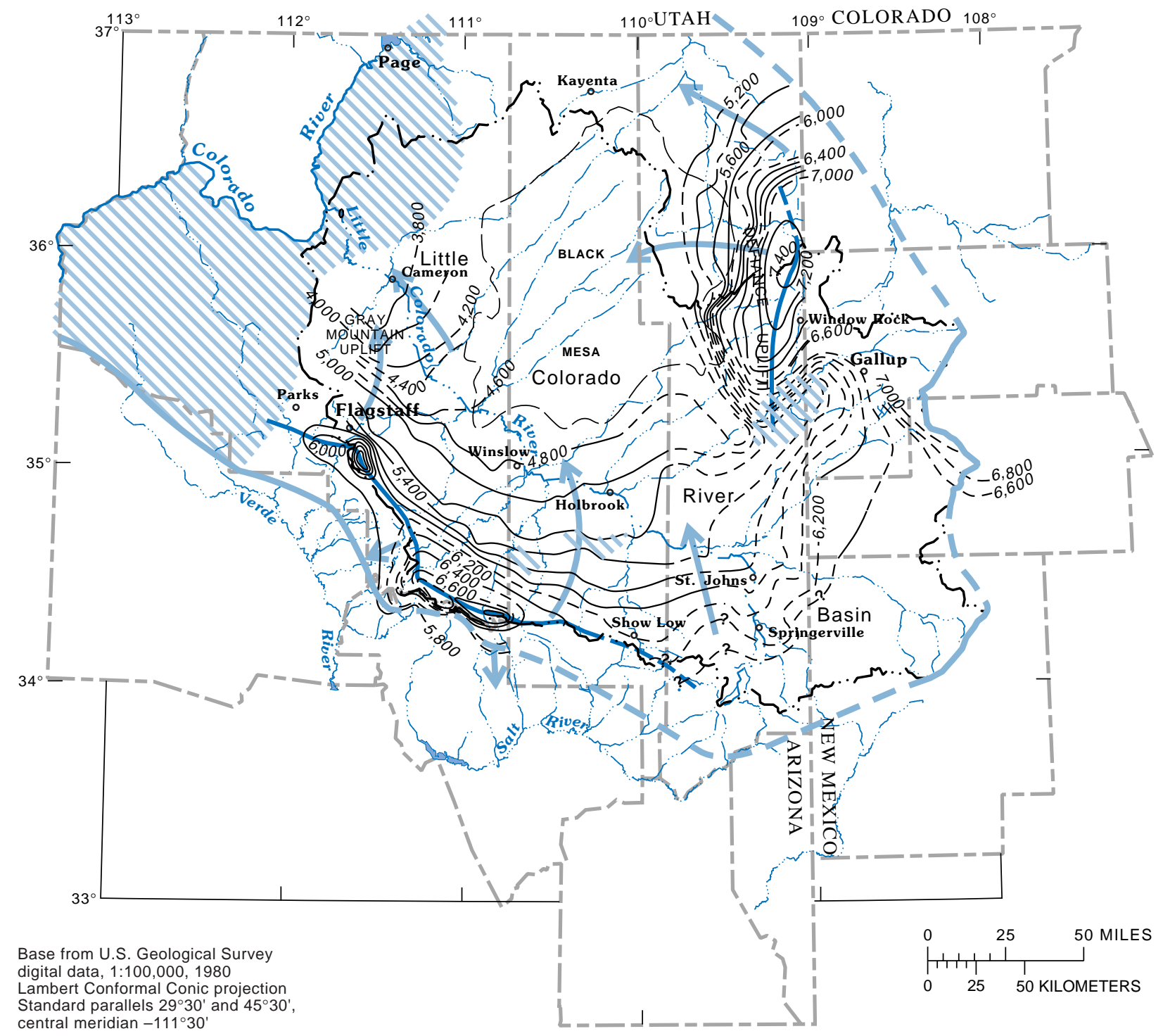

EXPLANATION

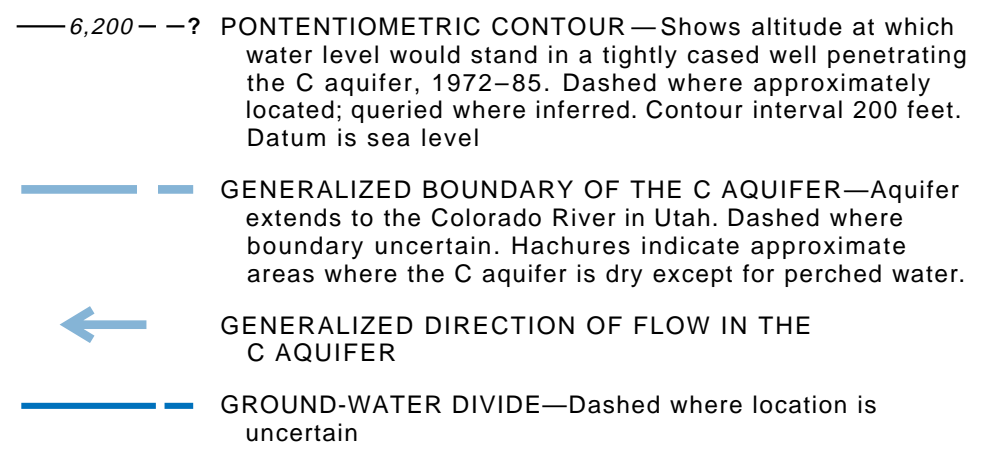

Figure 9. Potentiometric contours, direction of ground-water flow, and locations of ground-water divides in the $\mathrm{C}$ aquifer, Little Colorado River Basin and parts of the Verde and Salt River Basins, Arizona and New Mexico. Data based on previous work by McGavock and others (1986), Mann and Nemecek (1983), Mann (1976), Appel and Bills (1980 and 1981), Baldwin and Rankin (1995), Denis (1979), Levings and Farrar (1977a, b), Loughlin (1983), Orr (1987), Owen-Joyce and Bell (1983), and Ross (1977). 
Ground-water recharge to the $\mathrm{C}$ aquifer as downward leakage from overlying aquifers is difficult to characterize. The $\mathrm{C}$ aquifer is confined under the Black Mesa area by the overlying sequence of nearly impermeable Chinle and Moenkopi Formations that inhibit the downward movement of ground water from the $\mathrm{N}$ aquifer to the $\mathrm{C}$ aquifer. The Bidahochi aquifer directly overlies the $\mathrm{C}$ aquifer in a small area south of Interstate 40 near the Arizona-New Mexico State line. Downward leakage from the Bidahochi aquifer to the $\mathrm{C}$ aquifer is considered to be negligible in this area because of the presence of bentonite clays in the lower member of the Bidahochi Formation. Downward leakage from the Bidahochi aquifer to the $\mathrm{C}$ aquifer in other parts of the Little Colorado River Basin is considered to be negligible because in these areas the Bidahochi Formation is underlain by the Chinle and Moenkopi Formations. Where the Chinle and Moenkopi Formations are fractured significantly, leakage from the Bidahochi aquifer can occur; however, the amount of this leakage is unknown.

In the southeastern part of the Little Colorado River Basin, water in the Pinetop-Lakeside and White Mountain aquifers are perched several hundred feet above the $\mathrm{C}$ aquifer. Water in these aquifers moves laterally to discharge points in drainages where it either evaporates or infiltrates downward to the $\mathrm{C}$ aquifer. The amount of this type of recharge is unknown. In the southwestern part of the Little Colorado River Basin, near Flagstaff, water is perched several hundred to a thousand feet or more above the $\mathrm{C}$ aquifer in volcanic rocks. Significant downward leakage from these rocks to the $\mathrm{C}$ aquifer occurs where the rocks are heavily faulted and fractured. Geochemical analysis of water from the $\mathrm{C}$ aquifer indicates that water leaked from volcanic rocks is a significant component of the water in this area, but exact amounts are unknown (Bills and others, 2000). Alluvium along drainages also can contribute substantial leakage to the $\mathrm{C}$ aquifer where the alluvium overlies and is in direct contact with rock units of the $\mathrm{C}$ aquifer.

On the basis of available information, groundwater recharge to the $\mathrm{C}$ aquifer as upward leakage from the Redwall-Muav Limestone aquifer does not occur. The highest ground-water levels in the RedwallMuav Limestone aquifer are south of Lake Mary, near Flagstaff. Most of the spring discharge in this area results from downward leakage of water from the $\mathrm{C}$ aquifer through faults and other fractures to the deeper Redwall-Muav Limestone aquifer. The Redwall-Muav Limestone aquifer is confined in this area; however, the potentiometric surface is about $600 \mathrm{ft}$ below land surface, and the water level in the $\mathrm{C}$ aquifer is about $300 \mathrm{ft}$ below land surface (J.M.
Montgomery Consulting Engineers, Inc., 1982). This difference causes a net downward gradient from the $\mathrm{C}$ aquifer to the Redwall-Muav Limestone aquifer.

Ground-water discharge from the $\mathrm{C}$ aquifer occurs as (1) spring discharge north and south of the groundwater divide, (2) downward leakage to the deeper Redwall-Muav Limestone aquifer, (3) flow to streams in the Little Colorado River Basin, and (4) ET where the water table in the aquifer is at or near land surface (fig. 9).

North of the ground-water divide; spring discharge is primarily to the lower Little Colorado River from a network of springs, which includes Blue Springs. South of the ground-water divide, ground water discharges as springs in canyons along the escarpment of the Mogollon Rim and flows toward the Verde and Salt River Basins. Ground water from the $\mathrm{C}$ aquifer also discharges as springs on the Defiance Uplift in the drainages of Canyon de Chelly and in the upper reaches of the Black River.

Most of the spring discharge in the lower Little Colorado River and along the escarpment of the Mogollon Rim issues from the Redwall-Muav Limestone aquifer or from the Naco and Martin Formations. The $\mathrm{C}$ aquifer is highly fractured in many areas, and these fractures have been widened by solution, which allows ground water to leak downward to the Redwall-Muav Limestones and the Naco and Martin Formations.

Ground-water discharges from the $\mathrm{C}$ aquifer to the Little Colorado River from Lyman Lake downstream to Hunt Valley and from Woodruff to Joseph City; to Chinle Wash in Canyon de Chelly; to Bonito and Black Creeks in the Puerco River drainage; to Cottonwood Wash near Snowflake; and to Silver, Chevelon, and East Clear Creeks. West of the Little Colorado River Basin, the $\mathrm{C}$ aquifer probably is dry except where perched water occurs locally.

Ground-water discharge by ET from the $\mathrm{C}$ aquifer is considered to be insignificant compared to spring discharge because most of the aquifer is buried deeply below land surface. ET can occur along streams where native plants and phreatophytes are present and in areas near St. Johns, Hunt Valley, and south of Holbrook and Joseph City, where the water level in the aquifer is near land surface (fig. 10). These areas are small compared to the areal extent of the $\mathrm{C}$ aquifer.

\section{Hydraulic Characteristics}

Ground-water flow rates and well yields for the $\mathrm{C}$ aquifer correlate with the extent of fracturing and faulting of the Coconino Sandstone and sandstone beds in the Supai Group (Akers, 1962; Cooley, 1963). 
A.

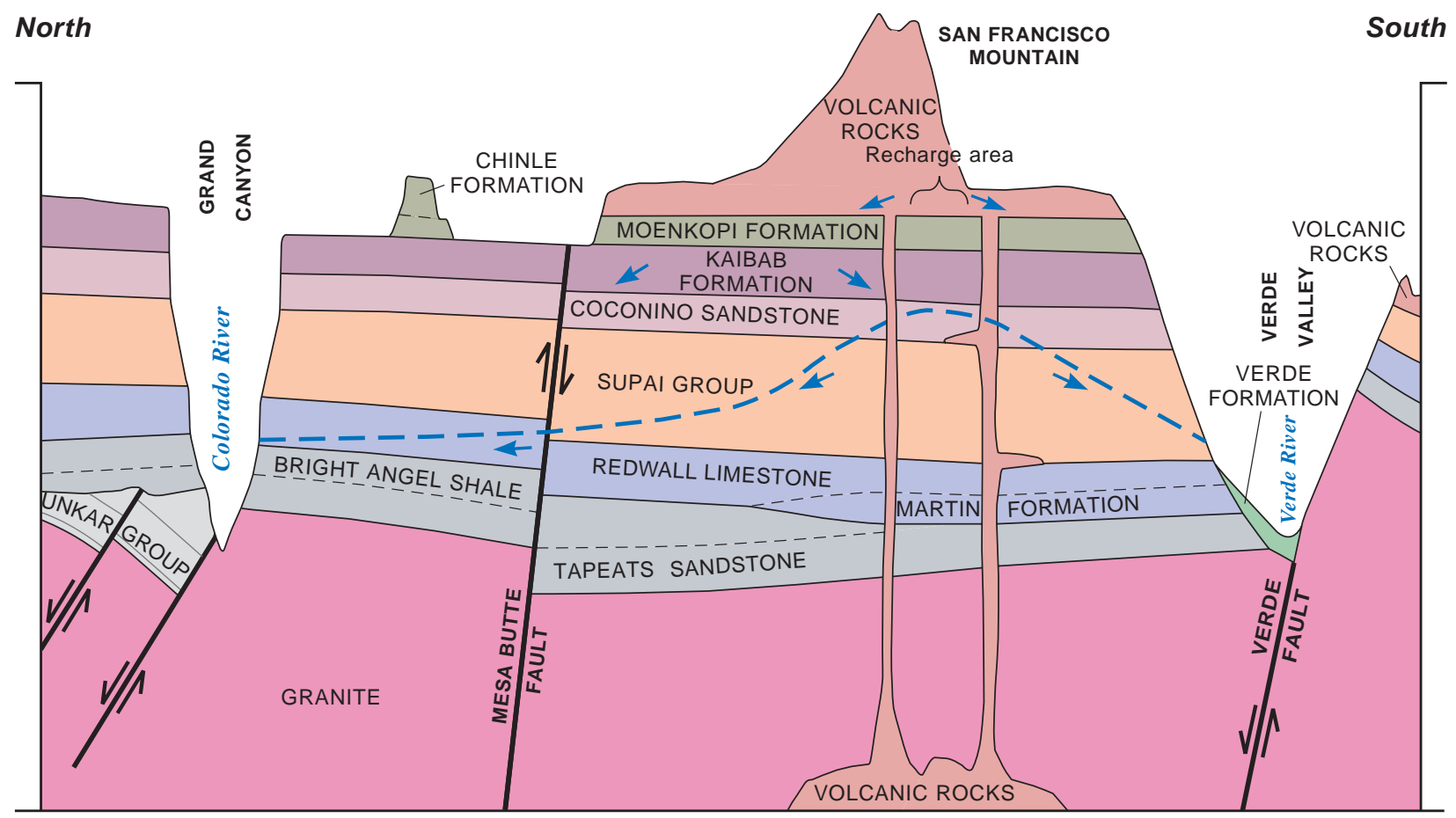

Modified from Breed, 1975

$B$.

West

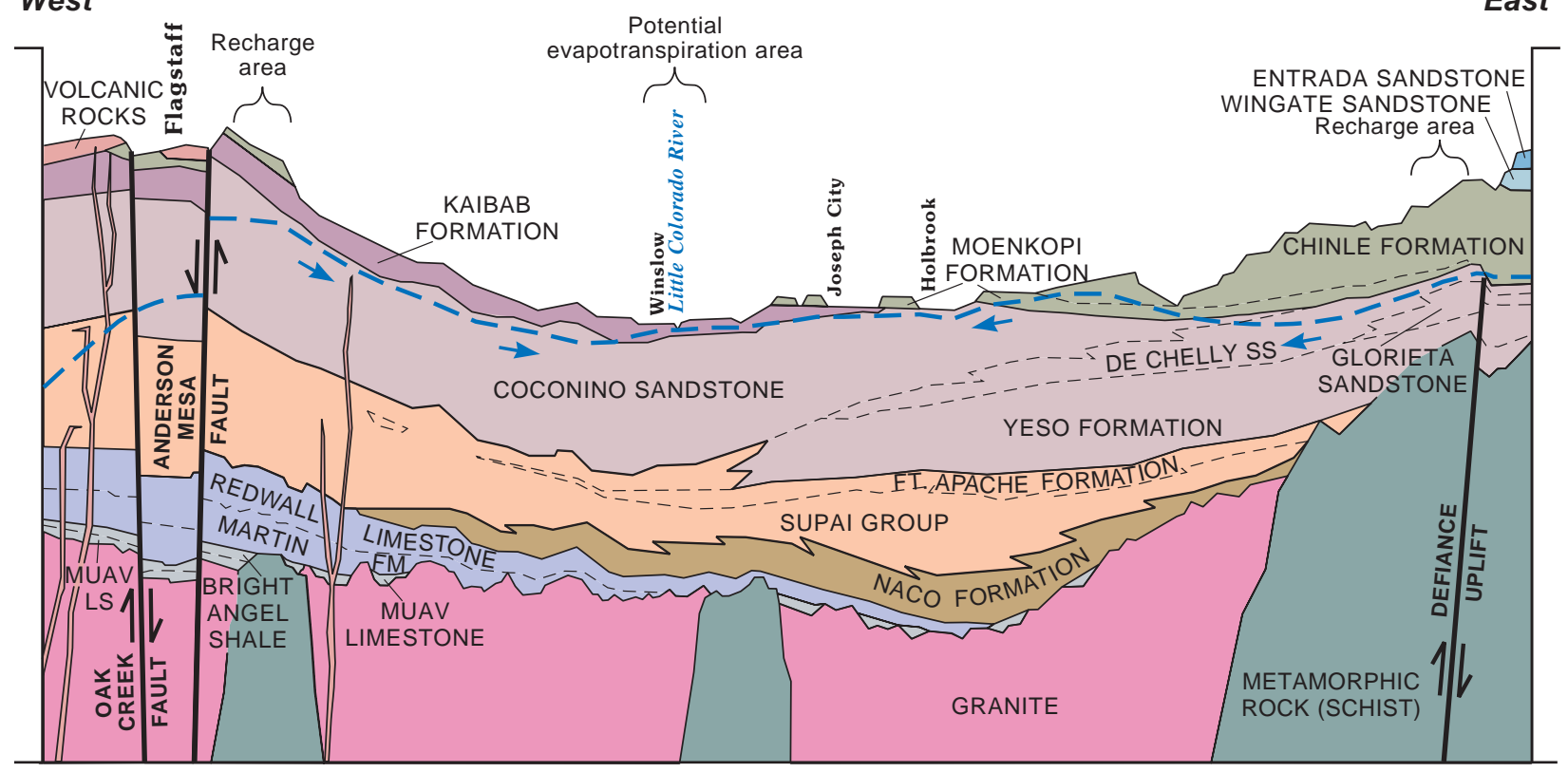

Modified from Billingsley and Breed, 1980

Figure 10. Generalized hydrogeologic sections of the Little Colorado River Basin and adjoining areas from $A$, the Colorado River to the Verde River and $B$, near Flagstaff, Arizona, along Interstate 40 to the Arizona-New Mexico State line. 


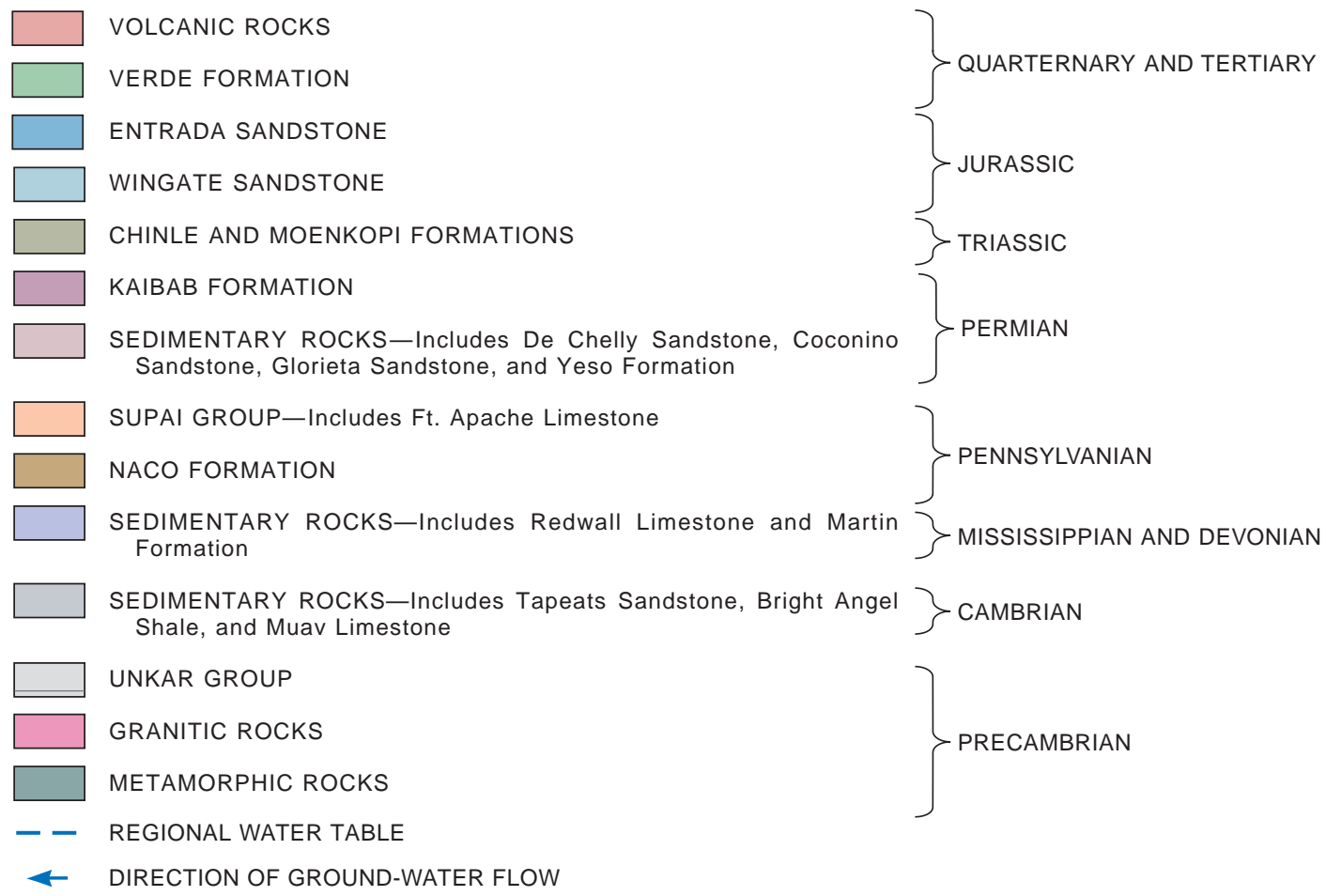

Figure 10. Continued.

Recent hydrogeologic investigations by the USGS near Flagstaff included mapping of extensive fracturing and correlation of well productivity and geologic structures (Bills and others, 2000). In the Lake Mary area south of Flagstaff, transmissivity values are 10 to 50 times greater than where the $\mathrm{C}$ aquifer is not fractured (Akers, 1962). Cooley (1963, p. 35) also describes the fractures in the $\mathrm{C}$ aquifer as follows:

The trends of the fractures as determined from the regional fault and joint patterns comprise a tightly spaced network that extends from the White Mountains northwestward across the Mogollon slope and San Francisco Plateau, Marble Platform, Kaibab Plateau, and into the western Grand Canyon region. Most of the fractures are aligned to the northwest, north, and northeast, and there is a general convergence of the fractures in the area of San Francisco Mountain near Flagstaff.
Well data are available in the GWSI to determine hydraulic properties, such as transmissivity, in some areas of the $\mathrm{C}$ aquifer. Most of the data (table 1) are from areas south of the Little Colorado River where the $\mathrm{C}$ aquifer is shallowest and is extensively used rather than from areas north of the river in the direction of the Black Mesa where the aquifer is buried deeply by younger rock units. Mann and Nemecek (1983) report transmissivity values of 940 to $9,100 \mathrm{ft}^{2} / \mathrm{d}$ for the $\mathrm{C}$ aquifer in the central part of Apache County. This wide range is in part a result of areal differences in lithology and fracturing. The USGS reported transmissivity and hydraulic conductivity values from about 45 wells near Flagstaff. Transmissivity values ranged from 1.34 to $4,690 \mathrm{ft}^{2} / \mathrm{d}$, and hydraulic conductivity values ranged from 0.14 to $81.5 \mathrm{~g} / \mathrm{d} / \mathrm{ft}^{2}$ (Bills and others, 2000). Selected wells in the study area and values of transmissivity and hydraulic conductivity are shown in table 2. 
a Table 2. Summary of selected well information and aquifer properties for the $C$ aquifer, Little Colorado River Basin, Arizona

[Saturated thickness of water column entering well through open interval (column $\mathrm{m}$ ) was calculated as: (1) the difference between the water level (column $\mathrm{h}$ ) and the bottom of the open interval (column I) if water level is below top of the open interval (column k), or (2) was calculated as the difference between the top (column $\mathrm{k}$ ) and bottom of the open interval (column l) if water level is above top of the open interval (column k), or (3) was calculated as the difference between the bottom of open interval (column l) and the water level (column $\mathrm{h}$ ) if top of open interval (column $\mathrm{k}$ ) was unknown. Data sources (column n): (1) U.S. Geological Survey Ground-Water Site Inventory; (2) McGavock and others (1968); (3) Bills and others, (2000). Dashes indicate no data. NA, not applicable]

\begin{tabular}{|c|c|c|c|c|c|c|c|c|c|c|c|c|c|c|c|c|c|}
\hline \multirow[b]{2}{*}{ Site name } & \multirow[b]{2}{*}{ Well number } & \multirow{2}{*}{ 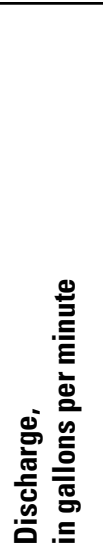 } & \multirow{2}{*}{ 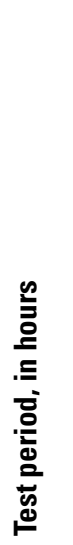 } & \multirow{2}{*}{ 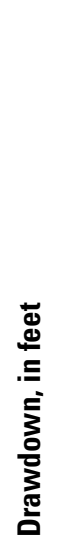 } & \multirow{2}{*}{ 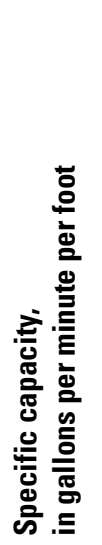 } & \multirow{2}{*}{ 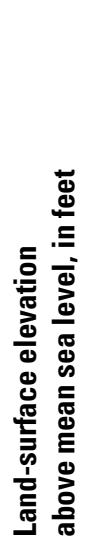 } & \multirow{2}{*}{ 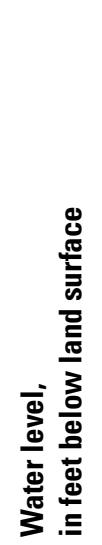 } & \multirow{2}{*}{ 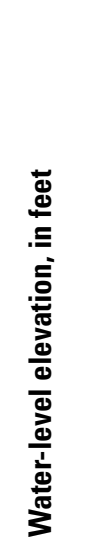 } & \multirow{2}{*}{ 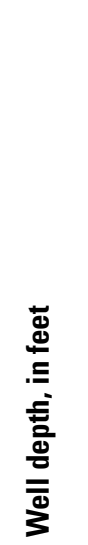 } & \multirow{2}{*}{ 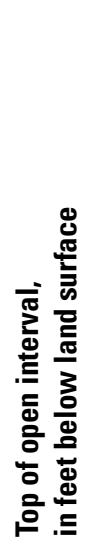 } & \multirow{2}{*}{ 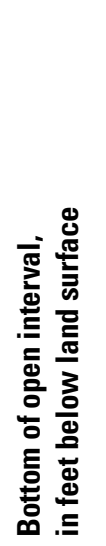 } & \multirow{2}{*}{ 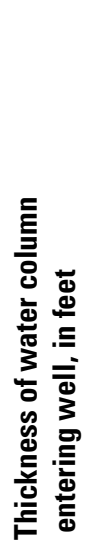 } & \multicolumn{2}{|c|}{ 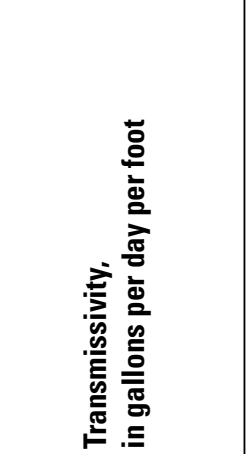 } & \multicolumn{2}{|c|}{ 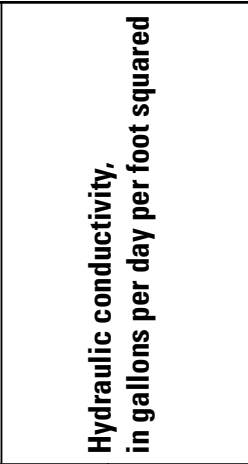 } & \multirow{2}{*}{ 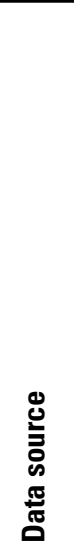 } \\
\hline & & & & & & & & & & & & & $\begin{array}{l}\text { Draw- } \\
\text { down }\end{array}$ & Recovery & $\begin{array}{l}\text { Draw- } \\
\text { down }\end{array}$ & Recovery & \\
\hline (a) & (b) & (c) & (d) & (e) & (f) & $(\mathbf{g})$ & (h) & (i) & (j) & $(\mathbf{k})$ & (I) & (m) & & (n) & & (o) & (p) \\
\hline Fuller 1 ............................... & (A-13-10)06daa & 395 & 72 & 31 & 12.7 & 6,865 & 347 & 6,518 & 567 & --- & 567 & 220 & --- & --- & --- & --- & 1,2 \\
\hline Virgil Hoake ...................... & $(\mathrm{A}-14-10) 32 \mathrm{dbd}$ & 525 & 24 & 20 & 26.3 & 6,855 & 344 & 6,511 & 600 & 102 & 600 & 256 & --- & --- & --- & --- & 1,2 \\
\hline Timber Ranger St ........... & $(\mathrm{A}-14-11) 09 \mathrm{dca}$ & 48 & 2 & 20 & 2.4 & 6,885 & 495 & 6,390 & 665 & -- & 665 & 170 & --- & --- & --- & --- & 2 \\
\hline Blue Ridge Camp ........... & (A-14-11)09adc & 43 & 9 & 21 & 2.05 & 6,905 & 532 & 6,373 & 670 & 532 & 670 & 138 & --- & --- & --- & --- & 2 \\
\hline Rock Crossing ................. & (A-14-11)30ddd & 11 & 16 & 5 & 2.2 & 7,323 & 841 & 6,482 & 1,000 & -- & 1,000 & 159 & --- & --- & --- & --- & 2 \\
\hline 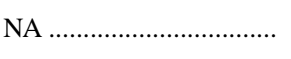 & (A-15-06)21ddc & 80 & --- & 49.3 & 1.62 & 3,810 & 26 & 3,784 & 129 & 100 & 120 & 20 & --- & --- & --- & --- & 1 \\
\hline NA …………………....... & (A-16-05)11bca & 69 & --- & 8 & 8.63 & 4,110 & 414 & 3,696 & 550 & 20 & 550 & 136 & --- & --- & --- & --- & 1 \\
\hline NA …………………….... & (A-16-05)14dad & 15 & --- & 6.7 & 2.24 & 4,085 & 382 & 3,703 & 500 & 160 & 500 & 118 & --- & --- & --- & --- & 1 \\
\hline Rancho Rojo No.1 .......... & $(\mathrm{A}-16-05) 24 \mathrm{acd}$ & 30 & 2 & 50 & .60 & 4,000 & 279 & 3,721 & 460 & 400 & 460 & 60 & --- & --- & --- & --- & 1 \\
\hline NA …………………...... & $(\mathrm{A}-16-06) 18 \mathrm{bbc}$ & 225 & --- & 18 & 12.5 & 4,140 & 375 & 3,765 & 500 & 427 & 486 & 59 & --- & --- & --- & --- & 1 \\
\hline Casa de Corte........................... & (A-16-06)08ccd & 20 & --- & 115 & .17 & 4,265 & 446 & 3,819 & 625 & 475 & 625 & 150 & --- & --- & --- & --- & 1,2 \\
\hline NA …………………....... & $(\mathrm{A}-17-05) 11 \mathrm{cdb}$ & 50 & --- & 1 & 50 & 4,415 & 568 & 3,847 & 735 & -- & 735 & 167 & --- & --- & --- & --- & 1 \\
\hline NA …………………....... & (A-17-05)14abd & 67 & --- & 20 & 3.35 & 4,360 & 475 & 3,885 & 700 & --- & 700 & 225 & --- & --- & --- & --- & 1 \\
\hline 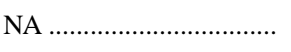 & (A-17-05)15aab & 118 & --- & 1 & 118 & 4,375 & 497 & 3,878 & 700 & 3 & 700 & 203 & --- & --- & --- & --- & 1 \\
\hline Sky Mountain .................... & (A-17-05)25aаa & 22 & --- & 23 & .96 & 4,400 & 596 & 3,804 & 750 & 70 & 750 & 154 & --- & --- & --- & --- & 1 \\
\hline NA …………......... & (A-17-05)26bca & 65 & --- & 100 & .65 & 4,000 & 60 & 3,940 & 126 & 60 & 126 & 66 & --- & --- & --- & --- & 1 \\
\hline
\end{tabular}


Table 2. Summary of selected well information and aquifer properties for the $C$ aquifer, Little Colorado River Basin, Arizona—Continued

\begin{tabular}{|c|c|c|c|c|c|c|c|c|c|c|c|c|c|c|c|c|c|}
\hline \multirow[b]{2}{*}{ Site name } & \multirow[b]{2}{*}{ Well number } & \multirow{2}{*}{ 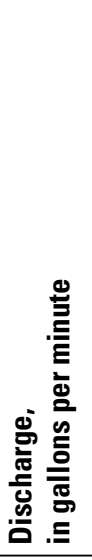 } & \multirow{2}{*}{ 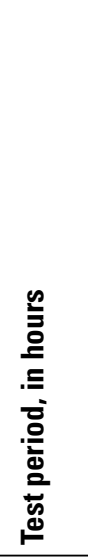 } & \multirow{2}{*}{ 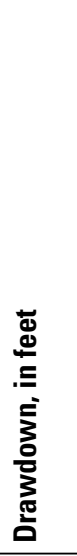 } & \multirow{2}{*}{ 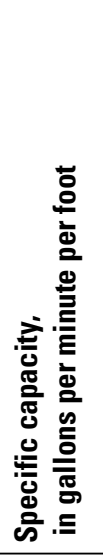 } & \multirow{2}{*}{ 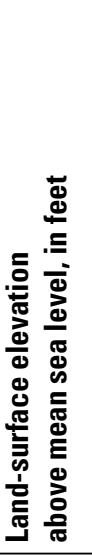 } & \multirow{2}{*}{ 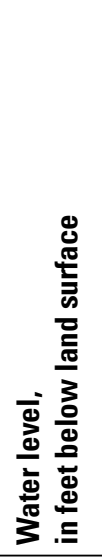 } & \multirow{2}{*}{ 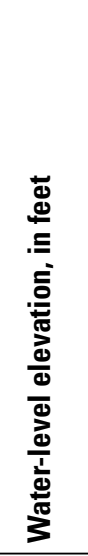 } & \multirow{2}{*}{ 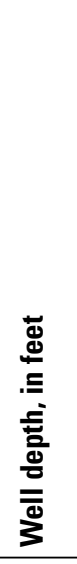 } & \multirow{2}{*}{ 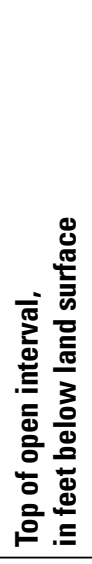 } & \multirow{2}{*}{ 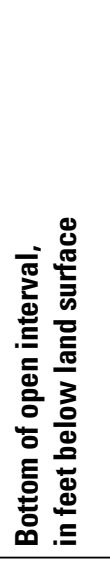 } & \multirow{2}{*}{ 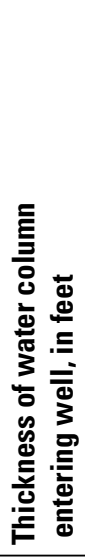 } & \multicolumn{2}{|c|}{ 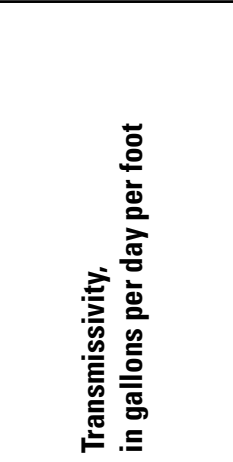 } & \multicolumn{2}{|c|}{ 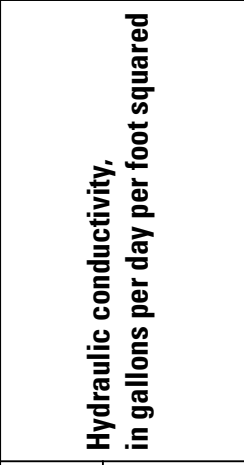 } & \multirow{2}{*}{ 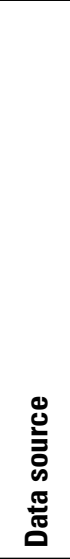 } \\
\hline & & & & & & & & & & & & & $\begin{array}{l}\text { Draw- } \\
\text { down }\end{array}$ & Recovery & $\begin{array}{l}\text { Draw- } \\
\text { down }\end{array}$ & Recovery & \\
\hline (a) & (b) & (c) & (d) & (e) & (f) & $(\mathbf{g})$ & (h) & (i) & (j) & (k) & (I) & $(\mathrm{m})$ & & (n) & & (o) & (p) \\
\hline 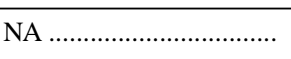 & (A-17-05)27ccd1 & 17 & --- & 10 & 1.7 & 4,045 & 340 & 3,705 & 520 & 340 & 520 & 180 & -- & --- & --- & --- & 1 \\
\hline 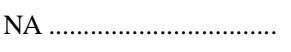 & (A-17-06)18dab & 5 & --- & 5 & 1 & 4,180 & 140 & 4,040 & 150 & 75 & 150 & 10 & -- & --- & --- & --- & 1 \\
\hline NA & (A-17-06)18add1 & 142 & --- & 5 & 28.4 & 4,240 & 278 & 3,962 & 500 & 320 & 500 & 180 & --- & --- & --- & --- & 1 \\
\hline NA & (A-17-06)19bbc2 & 19 & --- & 20 & .95 & 4,195 & 299 & 3,896 & 350 & --- & 350 & 51 & --- & --- & --- & --- & 1 \\
\hline NA …………………..... & $(\mathrm{A}-17-06) 30 \mathrm{abc}$ & 10 & --- & 30 & .33 & 4,335 & 483 & 3,852 & 850 & --- & 850 & 367 & -- & --- & --- & --- & 1 \\
\hline AWCOMP 5 .................... & (A-18-07) $15 \mathrm{cc} 2$ & 96 & 50 & 7.9 & 12.1 & 6,435 & 711 & 5,724 & 1,252 & 1,189 & 1,252 & 63 & --- & --- & --- & --- & 1 \\
\hline AWCOMP-10 ....................... & (A-18-07)22baa2 & 187 & --- & 11 & 17.0 & 6,455 & 713 & 5,742 & 1,330 & 904 & 1,304 & 400 & --- & --- & --- & --- & 1 \\
\hline WIFED \#1 Oil ............................. & (A-19-07)01ddd 1 & --- & --- & --- & --- & 7,175 & 420 & 6,758 & 730 & 405 & 730 & 310 & --- & --- & --- & --- & 1 \\
\hline LMEX 1 .......................... & (A-19-08) 05ddd1 & 330 & 12 & 83 & 4.0 & 6,960 & 153 & 6,807 & 1,203 & 272 & 1,161 & 889 & 2,500 & 2,600 & 2.81 & 2.92 & 1,3 \\
\hline Pine Grove CG ……............. & (A-19-09)17dcd & 15 & 5.5 & 25 & .60 & 6,958 & 1,309 & 5,649 & 1,700 & 1,439 & 1,700 & 261 & --- & --- & --- & --- & 1 \\
\hline Woody Mountain $\# 10 \ldots$ & (A-20-06)02bcb & 265 & 60 & 207 & 1.28 & 7,230 & 1,139 & 6,091 & --- & 1,300 & 1,760 & 460 & 4,460 & 4,013 & 6.97 & 6.27 & 1,3 \\
\hline Woody Mountain $\# 5$..... & (A-20-06)02bbc & 600 & 576 & 66 & 9.09 & 7,186 & 1,119 & 6,067 & 1,600 & 1,288 & 1,600 & 312 & --- & --- & --- & --- & 1 \\
\hline Woody Mountain \#7 ..... & (A-20-06)11 bab & 942 & 432 & 308 & 3.06 & 7,171 & 1,099 & 6,072 & 1,820 & 1,105 & 1,762 & 657 & 18,300 & 35,000 & 28.6 & 54.7 & 1,3 \\
\hline Forest Highland $4 \ldots \ldots \ldots \ldots$ & (A-20-06)24adb & 152 & 34 & 234 & .65 & 6,760 & 679 & 6,081 & 1,255 & 1,050 & 1,250 & 200 & 747 & --- & 1.29 & --- & 1,3 \\
\hline Forest Highland $5 \ldots \ldots \ldots$. & (A-20-06)24abb & 200 & 96 & 273 & .73 & 6,770 & 703 & 6,067 & 1,350 & 1,125 & 1,345 & 220 & 2,159 & 1,930 & 3.3 & 3.04 & 1,3 \\
\hline Lake Mary \#3 ......................... & (A-20-07)12ddb & 50 & 31 & 63 & .79 & 6,823 & 760 & 6,070 & 1,050 & 715 & 1,032 & 272 & 1,000 & 1,000 & 3.6 & 3.6 & 1,3 \\
\hline
\end{tabular}


Table 2. Summary of selected well information and aquifer properties for the $C$ aquifer, Little Colorado River Basin, Arizona—Continued

\begin{tabular}{|c|c|c|c|c|c|c|c|c|c|c|c|c|c|c|c|c|c|}
\hline \multirow[b]{2}{*}{ Site name } & \multirow[b]{2}{*}{ Well number } & \multirow{2}{*}{ 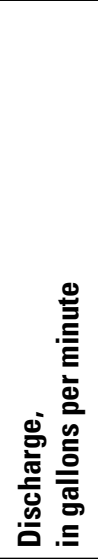 } & \multirow{2}{*}{ 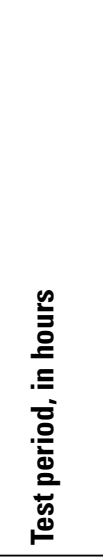 } & \multirow{2}{*}{ 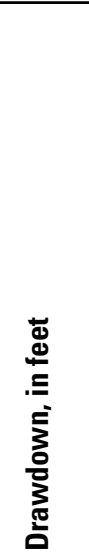 } & \multirow{2}{*}{ 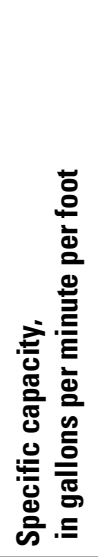 } & \multirow{2}{*}{ 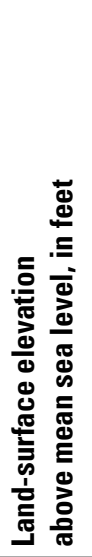 } & \multirow{2}{*}{ 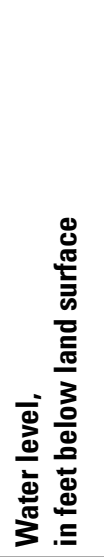 } & \multirow{2}{*}{ 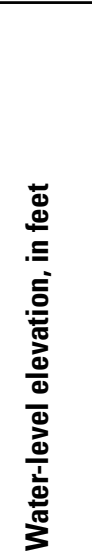 } & \multirow{2}{*}{ 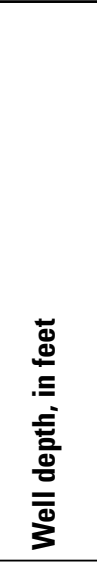 } & \multirow{2}{*}{ 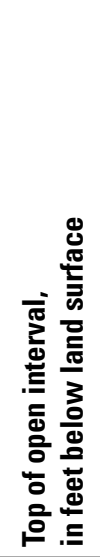 } & \multirow{2}{*}{ 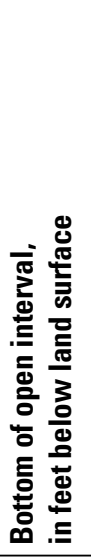 } & \multirow{2}{*}{ 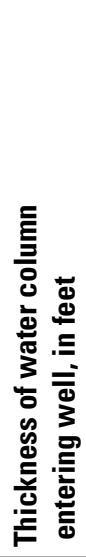 } & \multicolumn{2}{|c|}{ 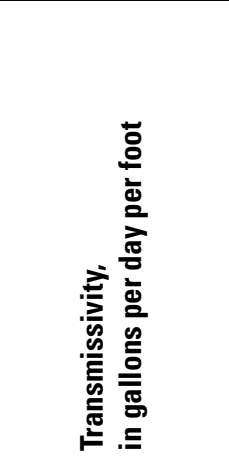 } & \multicolumn{2}{|c|}{ 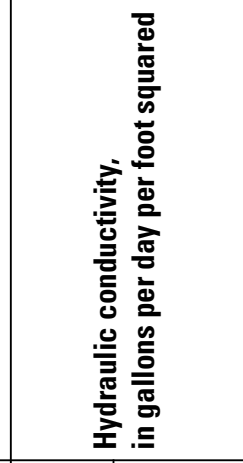 } & \multirow{2}{*}{ 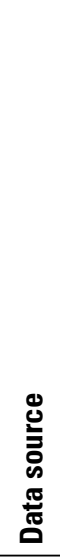 } \\
\hline & & & & & & & & & & & & & $\begin{array}{l}\text { Draw- } \\
\text { down }\end{array}$ & $\begin{array}{c}\text { Recover } \\
y\end{array}$ & $\begin{array}{l}\text { Draw- } \\
\text { down }\end{array}$ & $\begin{array}{c}\text { Recover } \\
y\end{array}$ & \\
\hline (a) & (b) & (c) & (d) & (e) & (f) & (g) & (h) & (i) & (j) & (k) & (I) & (m) & & (n) & & o) & (p) \\
\hline FH Test Well......................... & (A-20-07)19cbb1 & --- & --- & --- & --- & 6,690 & 635 & 6,055 & 1,200 & 730 & 1,179 & 449 & --- & --- & --- & --- & 1 \\
\hline FH 3 & (A-20-07)19aba & 90 & 74 & 245 & .37 & 6,900 & 865 & 6,035 & 1,412 & 1,265 & 1,405 & 140 & 456 & --- & 0.83 & --- & 1,3 \\
\hline 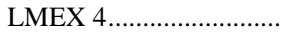 & (A-20-07)25dcb1 & --- & --- & --- & --- & 6,840 & 170 & 6,670 & 1,200 & 340 & 1,060 & 720 & 100 & 100 & 0.14 & 0.14 & 1,3 \\
\hline LMEX $2 \ldots \ldots \ldots \ldots \ldots \ldots \ldots \ldots \ldots$ & $(\mathrm{A}-20-08) 33 \mathrm{cdb}$ & 69 & 12 & 63 & 1.1 & 6,940 & 441 & 6,529 & 1,203 & 442 & 1,161 & 719 & 800 & 700 & 1.11 & 0.97 & 1,3 \\
\hline 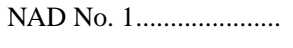 & $(\mathrm{A}-21-05) 11 \mathrm{cbc}$ & 35 & --- & 100 & .35 & 7,040 & 1,273 & 5,767 & 1,647 & 1,500 & 1,647 & 147 & --- & --- & --- & --- & 1 \\
\hline Woody Mountain \#4 ....... & $(\mathrm{A}-21-06) 35 \mathrm{ccc}$ & 490 & 4,632 & 211 & 2.32 & 7,166 & 1,065 & 6,101 & 1,540 & 1,213 & 1,518 & 305 & 5,700 & 8,600 & 13.9 & 20.9 & 1,3 \\
\hline Woody Mountain \#3..... & $(\mathrm{A}-21-06) 35 \mathrm{bcc}$ & 500 & 4,440 & 92 & 5.43 & 7,130 & 1,213 & 5,917 & 1,602 & 1,300 & 1,600 & 300 & 14,500 & 20,000 & 37.7 & 51.9 & 1,3 \\
\hline Woody Mountain \#2 ..... & $(\mathrm{A}-21-06) 35 \mathrm{ccb}$ & 362 & 4,440 & 33 & 11 & 7,167 & 1,246 & 5,921 & 1,746 & 1,200 & 1,397 & 151 & 18,150 & 21,850 & 48.4 & 58.3 & 1,3 \\
\hline Woody Mountain \#1 ..... & $(\mathrm{A}-21-06) 35 \mathrm{cba}$ & 207 & 168 & 68 & 3.04 & 7,140 & 1,227 & 5,913 & 1,600 & 1,329 & 1,580 & 251 & 29,600 & 28,700 & 81.5 & 79.1 & 1,3 \\
\hline Mt Dell 1 ............................ & $(\mathrm{A}-21-07) 32 \mathrm{bbc} 1$ & 206 & 1 & 100 & 2.06 & 6,910 & 985 & 5,925 & 1,200 & 150 & 1,200 & 215 & --- & --- & --- & --- & 1 \\
\hline Cosnino................................. & $(\mathrm{A}-21-09) 08 \mathrm{bcc}$ & 30 & 12.5 & 130 & .23 & 6,450 & 1,349 & 5,101 & 1,715 & --- & 1,710 & 361 & --- & --- & --- & --- & 1 \\
\hline Winona TP............................ & (A-21-09)14acc & 8 & 2 & 8.8 & .85 & 6,270 & 1,205 & 5,065 & 1,320 & 1,200 & 1,320 & 115 & --- & --- & --- & --- & 1,2 \\
\hline Tribal Well 5T-320 ........ & $(\mathrm{A}-21-12.5) 36 \mathrm{bd}$ & 10 & 8 & 0 & --- & 5,167 & 460 & 4,707 & 553 & 239 & 553 & 93 & --- & -- & --- & --- & 1 \\
\hline BBDP-Marijka.................... & $(\mathrm{A}-22-08) 23 \mathrm{abb}$ & 177 & 24 & 44 & 4.02 & 6,575 & 1,500 & 5,075 & 1,802 & 1,520 & 1,800 & 280 & 5,897 & --- & 19.5 & --- & 1,3 \\
\hline Tribal Well 5T-505 ........ & $(\mathrm{A}-22-13) 18 \mathrm{cb}$ & 35 & 3 & .5 & 70 & 4,765 & 140 & 4,625 & 425 & 133 & 425 & 285 & --- & --- & --- & --- & 1 \\
\hline Citadel ……….................... & $(\mathrm{A}-25-09) 06 \mathrm{ccd}$ & 18 & 49 & 5.0 & 3.5 & 5,381 & 1,583 & 3,801 & 1,788 & 1,780 & 1,788 & 8 & 841 & --- & 28.5 & 6.2 & 1,3 \\
\hline Wupatki ........................... & $(\mathrm{A}-25-10) 30 \mathrm{bdb}$ & 50 & 24 & 45 & 1.11 & 4,930 & 781 & 4,149 & 904 & 800 & 904 & 104 & 1,269 & --- & 10.3 & --- & 1,3 \\
\hline
\end{tabular}




\section{Redwall-Muav Limestone Aquifer}

The Redwall and Muav Limestones are the primary water-bearing rock units underlying the $\mathrm{C}$ aquifer in the Little Colorado River Basin and constitute the Redwall-Muav Limestone aquifer. The limestones are discussed in this report because of their hydraulic connection with the overlying $\mathrm{C}$ aquifer. Along the Mogollon Rim in southern Coconino County, the Devonian age Martin Formation and other intervening rock units are connected hydraulically to the Redwall and Muav Limestones and are units of the aquifer.

The Redwall Limestone is about $400 \mathrm{ft}$ thick near the mouth of the Little Colorado River and thins progressively southeastward toward Holbrook. The formation is not present in the Defiance Uplift area nor in the area eastward into New Mexico.

The formation dips in all directions to a structural low in the Black Mesa area, northeastward into the San Juan Basin of New Mexico (Irwin and others, 1971), and northwestward into the Kaiparowits Basin in Utah (McKee, 1963). Outcrops of the Redwall Limestone are not extensive in the Little Colorado River Basin, and exposures are structurally downdip from and at the lowest altitudes below the Mogollon Rim. The Martin Formation, which underlies the Redwall Limestone, yields modest amounts of water to springs along the Mogollon Rim (McGavock and others, 1986).

The Muav Limestone is part of the Tonto Group, which also consists of the Tapeats Sandstone and Bright Angel Shale. The Tonto Group thins generally to the southeast from the Grand Canyon and is absent in the Defiance Uplift. McKee (1945, p. 141) reported $414.5 \mathrm{ft}$ of unclassified Cambrian deposits and Muav Limestone in a section east of Lava Canyon, about 4 mi south of the Little Colorado River. During the drilling of an oil test well in the northwestern part of the Navajo Indian Reservation, $315 \mathrm{ft}$ of rock believed to be correlative with the Muav Limestone was penetrated (Irwin and others, 1971). The Muav Limestone is the lower and less productive unit of the Redwall-Muav Limestone aquifer, and only a few springs issue from the unit; these springs are in Marble Canyon and near the mouth of the Little Colorado River (Irwin and others, 1971). The Muav Limestone is underlain by the Bright Angel Shale, which generally is impermeable, and the Tapeats Sandstone.
The Redwall-Muav Limestone aquifer pinches out west of the Defiance Uplift. West of the Little Colorado River Basin the aquifer extends beneath the Coconino Plateau westward to the Aubrey Cliffs near Seligman, west of the study area. A ground-water divide in the Redwall-Muav aquifer that generally follows the western boundary of the Little Colorado River Basin has been described by Loughlin (1983) and Errol L. Montgomery and Associates (1996). The regional downcutting by the Colorado River (the northwest boundary of the Little Colorado River Basin) below Paleozoic rock units has dewatered the Redwall and Muav Limestones from near the mouth of the Little Colorado River west to the south rim of the Grand Canyon. The aquifer extends southward to the Verde and Salt Rivers. The location of the boundary of the aquifer southeast of the Little Colorado River Basin in New Mexico is unknown because of the paucity of well and water-level data in this area.

Ground water from the aquifer issues from springs in the Redwall and Muav Limestones in the Grand Canyon near the Eminence Break (Huntoon, 1981), in the lower Little Colorado River at and near Blue Springs (Cooley, 1976), in the Verde Valley, and along the Mogollon Rim. Recharge to the Redwall-Muav Limestone aquifer is primarily leakage from overlying rock units; direct infiltration through outcrops is considered negligible.

Ground-water data for the Redwall-Muav Limestone aquifer are sparse, and few wells are drilled into the aquifer because of the depth of the aquifer below land surface. Drill-stem test information from oil and gas wells (Peirce and Scurlock, 1972) are available only for the Little Colorado River Basin north of Chinle, in an area between Winslow and Show Low, and to the northeast of Tuba City. Because of the scarcity of data, the movement of ground water in the aquifer largely is unknown. The aquifer could be expected to have low hydraulic conductivity because of its lithology and depth of burial; however, the Redwall Limestone contains many solution channels and cavities developed along bedding planes, faults, and joints. High secondary permeability associated with the fracture systems in the Redwall and Muav Limestones provides a mechanism for transmitting ground water and for the aquifer to discharge large quantities of water to springs, such as Blue Springs in the lower Little Colorado River. 


\section{GROUND-WATER DEVELOPMENT}

There was little ground-water development in the $\mathrm{C}$ aquifer prior to the 1940s. According to Mann (1976), the amount of water withdrawn from the Coconino aquifer in southern Navajo County increased from about 3,300 acre-ft in 1946 to about 11,500 acre-ft in 1972. Thirty-two percent of the water pumped during 1972 was used for irrigation. Total ground-water production from all aquifers in southern Coconino County was estimated to be 2,600 acre-ft in 1970. In 1975, the amount increased to 5,200 acre-ft (McGavock and others, 1986).

More accurate records of ground-water use for the entire Little Colorado River Basin began during the mid-1970s (table 3). The sparse population of the basin and the remoteness of the region have resulted in a pace of development that generally has lagged behind that of other areas in Arizona. This condition may be viewed positively by water-resource managers because it allows them to take advantage of the experiences gained in other areas of the State in planning for and establishing ground-water development in the basin. Ground-water development in the basin has progressed mainly in response to increasing use of water by industry and municipalities.

Development of the $\mathrm{C}$ aquifer in the Black Mesa area and in the parts of the basin in New Mexico has been slow compared with development of the $\mathrm{C}$ aquifer in the rest of the basin. Increases in population and the relocation of many families on the Navajo Reservation resulted in modest increases in pumpage from the $\mathrm{C}$ aquifer west of the Defiance Uplift. Small increases in population and tourism on the Zuni Indian Reservation account for most of the increased use of ground water in New Mexico, and subsistence agriculture and domestic use accounts for the rest.

Ground-water development of the $\mathrm{C}$ aquifer south of the Little Colorado River is in the form of largevolume production wells for irrigation, industrial, and municipal purposes. Ground water north of the river generally is deep below land surface; therefore, drilling wells in that area is more expensive than drilling wells south of the river. Wells north of the river typically have not been constructed for maximum productivity because of the depth to ground water, the associated drilling costs, and the use of water for domestic and livestock purposes.

Table 3. Estimated ground-water withdrawals from the C aquifer, Arizona and New Mexico, 1976-95

[Values are in acre-feet]

\begin{tabular}{rcccc}
\hline Year & Agricultural & Industrial & $\begin{array}{l}\text { Public } \\
\text { supply }\end{array}$ & Total \\
\hline 1976 & 38,600 & 16,900 & 13,600 & 69,100 \\
1977 & 40,400 & 19,800 & 18,100 & 78,300 \\
1978 & 41,700 & 25,800 & 17,700 & 85,200 \\
1979 & 34,000 & 26,800 & 19,100 & 79,900 \\
1980 & 39,800 & 31,600 & 16,100 & 87,500 \\
1981 & 35,200 & 41,200 & 19,700 & 96,100 \\
1982 & 40,300 & 39,500 & 22,400 & 102,200 \\
1983 & 33,700 & 35,400 & 22,000 & 91,100 \\
1984 & 27,600 & 39,800 & 23,200 & 90,600 \\
1985 & 26,000 & 41,900 & 23,300 & 90,200 \\
1986 & 37,800 & 37,100 & 23,400 & 98,300 \\
1987 & 30,900 & 39,400 & 23,300 & 93,600 \\
1988 & 38,000 & 41,700 & 24,900 & 104,600 \\
1989 & 48,200 & 46,700 & 32,100 & 127,000 \\
1990 & 44,300 & 46,500 & 32,100 & 122,900 \\
1991 & 47,100 & 47,200 & 32,700 & 127,000 \\
1992 & 46,100 & 47,700 & 33,000 & 126,800 \\
1993 & 45,800 & 48,900 & 32,600 & 127,300 \\
1994 & 45,100 & 53,000 & 34,100 & 132,200 \\
1995 & 49,300 & 52,000 & 38,800 & 140,100 \\
\hline
\end{tabular}

In general, the effects of ground-water development on the $\mathrm{C}$ aquifer have been localized in the south-central part of the basin near industrial sites where ground-water level declines are greatest. Ground-water levels have declined as much as $100 \mathrm{ft}$ in two triangular areas: one formed by Joseph City, Holbrook, and Snowflake, and one formed by Concho, St. Johns, and Springerville. Available data do not indicate that cones of depression caused by pumping have stabilized; however, the cones of depression have not reached the boundary of the aquifer or caused a decline in the discharge from springs or base flow along the periphery of the $\mathrm{C}$ aquifer.

Population increases in the basin will result in greater demands for municipal water. Use of ground water from the $\mathrm{C}$ aquifer for agricultural development 
is expected to continue to fluctuate as farmers trade off surface-water and ground-water uses on the basis of available supplies and costs. Use of water from the $\mathrm{C}$ aquifer on reservation lands is expected to increase as the Navajo, Hopi, and Zuni Indian communities look for additional water resources to meet their needs. The amount of ground water discharged from wells in the $\mathrm{C}$ aquifer in 1995 was about 140,000 acre-ft. Prior to the 1940 s, total withdrawals from wells probably was about 5,000 acre-ft/yr.

\section{INTERACTION OF GROUND WATER AND SURFACE WATER}

The $\mathrm{C}$ aquifer in the Little Colorado River Basin and parts of the Verde and Salt River Basins is connected hydraulically to certain reaches of the Little Colorado River, its tributaries, and streams draining south from the Mogollon Rim. In this type of system, aquifers either discharge water to the surfacewater body as base flow or receive water from the surface-water body as recharge. Ground-water and surface-water interaction is dependent on the characteristics of the rock units that make up the stream channel and (or) on the ground-water level. Excessive ground-water withdrawals or drought conditions can cause water levels to decline and, therefore, reduce base flow in streams that intersect the water table.

Certain reaches of the Little Colorado River are perennial because of ground-water discharge from the $\mathrm{C}$ aquifer (fig. 4). Reaches of the Little Colorado River that historically have had base flow maintained by discharge from aquifers include (1) Lyman Lake to below Hunt Valley, (2) near Woodruff downstream to Holbrook, and (3) a small reach near Winslow (Brown and others, 1978). Perennial reaches in the Lyman Lake area probably result from discharge from the $\mathrm{C}$ aquifer even though flow in the river is regulated below Lyman Lake Dam. Other reaches of the Little Colorado River were perennial before diversions and impoundments were in place or before ground-water levels declined. These reaches include (1) below Zion Reservoir to the mouth of Silver Creek and (2) from Holbrook downstream to the mouth of East Clear Creek (Brown and others, 1978). Flow in these reaches may have been directly affected by ground-water pumping during the late 1960s and early 1970s. Mann and Nemecek (1983) reported that wells between Lyman Lake and the western Apache County line and along Carrizo Wash that penetrate the $\mathrm{C}$ aquifer flowed at land surface from 1945 to 1961 . By 1976, the yield from many wells had decreased, and some wells had ceased to yield water. Mann and Nemecek (1983) attributed the decline in the potentiometric surface to withdrawal of ground water from wells, and the loss of confining pressure to the deterioration of the well casings. Mann (1976) also noted that pumping in southern Navajo County had caused springs to stop flowing, and that they only flowed during the winter months when there was no pumping for irrigation.

The lower 13-mi reach of the Little Colorado River is perennial as a result of spring flow from the Redwall and Muav Limestones. The occurrence of the springs is controlled mainly by many normal faults that converge in the area. This structure allows water in the overlying $\mathrm{C}$ aquifer to flow rapidly down through solution channels and fractures to the Redwall-Muav Limestone aquifer. Although this area has long been recognized as the main regional drain of ground water from the Little Colorado River Basin, there is little information to indicate the primary source of the water. Cooley (1976) suggests that most of the water originates in the Black Mesa area; however, Loughlin (1983) suggests that as much as 75 percent originates at the volcanic field of San Francisco Mountain near Flagstaff.

Several tributaries of the Little Colorado River, including the lower reaches of Clear Creek, Chevelon Creek, and Silver Creek, have base flows that are maintained by ground-water discharge from the $\mathrm{C}$ aquifer (table 4). Other smaller tributaries drain the $\mathrm{C}$ aquifer; however, the water is lost by ET or reinfiltrates before the flow reaches the Little Colorado River. Tsaile, Wheatfields, Whiskey, and Coyote Creeks drain the western escarpment of the Chuska Mountains. Flows from these creeks drain to Canyon de Chelly and eventually join Chinle Wash, which is within the San Juan River Basin. Tsaile Creek is perennial; however, flows are interrupted during extreme drought conditions. Flows in Canyon de Chelly are maintained in part by ground-water discharge from the $\mathrm{C}$ aquifer, and the water eventually percolates into the sandy alluvium (Cooley and others, 1969, p. 38). Bonito Creek flows into Black Creek west of Fort Defiance and receives ground-water discharge from the De Chelly Sandstone and the Supai Group. Kinlichee Creek drains the $\mathrm{C}$ aquifer southwest of the Defiance Plateau. Some streams tributary to the Verde and Salt Rivers, including Carrizo, Sycamore, Wet Beaver, Fossil, and West Clear Creeks, also have large flows that are maintained by ground-water discharge from downward leakage from the $\mathrm{C}$ aquifer (table 4). 
Table 4. Estimated spring discharge as base flow at streamflow-gaging stations of the U.S. Geological Survey in Arizona

[Base flows are estimated using monthly minimum discharge for November, December, January, and February, for period of record (Pope and others, 1998)]

\begin{tabular}{|c|c|c|c|c|}
\hline $\begin{array}{l}\text { Station } \\
\text { number }\end{array}$ & Period of record & Station name & $\begin{array}{c}\text { Discharge, } \\
\text { in acre-feet } \\
\text { per year }\end{array}$ & $\begin{array}{l}\text { Drainage area, } \\
\text { in square miles }\end{array}$ \\
\hline \multicolumn{5}{|c|}{ Streams flowing north of the ground-water divide in the area of the Mogollon Rim } \\
\hline 9394500 & $1906,1930-33,1936-96$ & Little Colorado River near Woodruff & 1,950 & 8,072 \\
\hline 9398000 & $1917-19,1930-33,1936-72$ & Chevelon Creek near Winslow & 1,950 & 785 \\
\hline 9395900 & $1965-72,1975-78,1980-82$ & Black Creek near Lupton & 41.6 & 500 \\
\hline \multirow[t]{2}{*}{9397000} & $1906,1950-73$ & Little Colorado River at Holbrook & 2,590 & 11,462 \\
\hline & & Total base flow northward & 6,532 & \\
\hline \multicolumn{5}{|c|}{ Streams flowing south of the ground-water divide in the area of the Mogollon Rim } \\
\hline 9504500 & $1941-96$ & Oak Creek near Cornville & 21,140 & 355 \\
\hline 9505200 & $1962-82,1991-96$ & Wet Beaver Creek near Rimrock & 4,570 & 111 \\
\hline 9505800 & $1966-96$ & West Clear Creek near Camp Verde & 11,200 & 241 \\
\hline 9496500 & $1952-60,1968-75,1978-96$ & Carrizo Creek near Show Low & 3,270 & 439 \\
\hline 9497800 & 1960-96 & Cibicue Creek near Chrysotile & 7,610 & 295 \\
\hline 9507600 & $1962-71$ & East Verde River near Pine & 452 & 6.34 \\
\hline \multirow[t]{2}{*}{9507700} & $1960-74$ & $\begin{array}{l}\text { Webber Creek above } \\
\text { West Fork Webber Creek near Pine }\end{array}$ & 293 & 4.79 \\
\hline & & Total base flow southward & 48,535 & \\
\hline
\end{tabular}

\section{GROUND-WATER BUDGET}

In the development of a ground-water budget (or balance), a control volume is defined. The control volume of interest in this study is the $\mathrm{C}$ aquifer that underlies the Little Colorado River Basin and parts of the Verde and Salt River Basins south of the Mogollon Rim. The basic form of any ground-water budget equation is:

$\Sigma($ inflows $)-\Sigma($ outflows $)-\Delta$ storage $=0$.

$\Sigma$ (inflows) is the summation of inflow components expressed as a volume of water per unit time with a positive sign convention for flow into the control volume. $\Sigma$ (outflows) is the summation of outflow components expressed as a volume of water per unit time with a positive sign convention for flow out of the control volume. Change in storage ( $\Delta$ storage) for the control volume is expressed as a volume of water per unit of time with a sign convention that can be either positive or negative. Change in storage is the net gain or loss of water from the control volume resulting from changes in the inflow or outflow components. Changes in inflow can be natural in response to long- or shortterm climate variations, or man-made, such as those caused by surface-water diversions.

In natural ground-water flow systems without development, the amount of water stored in the control volume is constant or varies about some average in response to annual or longer-term climatic variations. This condition is referred to as a steady-state condition or predevelopment condition. The rate of change in storage in the ground-water budget is negligible for an aquifer in a steady-state condition because the assumption is made that inflows and outflows are in balance. In the case of the $\mathrm{C}$ aquifer and for the purposes of this analysis, the ground-water budget equation is expressed as:

$$
\Sigma(\text { inflows })-\Sigma(\text { outflows })=0 \text {. }
$$

As humans change the natural or predevelopment flow system by withdrawing ground water or changing vegetation or drainage conditions, inflow and outflow are no longer equal, and the difference is made up by a change in storage. This condition is 
referred to as the transient condition. The $\mathrm{C}$ aquifer is considered to be in a transient condition because water levels are declining, an indication that the amount of water in storage is changing in many areas of the Little Colorado River Basin.

An estimated ground-water budget for a steadystate condition was made from analysis of existing information. This analysis provides a broad-scale predevelopment ground-water budget for the aquifer underlying the Little Colorado River Basin and surrounding areas.

\section{Ground-Water Budget Components.- As}

illustrated in equation 1, the ground-water budget consists of both inflow (recharge) and outflow (discharge) components. No recharge data were available for this report and, therefore, only outflow components shown in equation 3 were evaluated. Recharge components to the $\mathrm{C}$ aquifer are direct infiltration of precipitation; infiltration from perennial surface-water reaches, lakes and overlying aquifers; and underflow. Recharge in its various forms cannot be measured directly, but under steady-state conditions it can be assumed that recharge is equal to discharge (outflow). Therefore, recharge is equal to the sum of the outflow components presented in equation 3 :

\section{Recharge $=$ Surface Discharge + Downward leakage + ET + Underflow .}

Discharge components were estimated for the known physical boundaries of the ground-water flow system (the control volume) of the $\mathrm{C}$ aquifer (fig. 9). Most outflow from the $\mathrm{C}$ aquifer occurs as surface discharge (comprised of discharge to streams as base flow and discharge to springs) and downward leakage. Discharge of water from the $\mathrm{C}$ aquifer to lakes and irrigation canals can occur in the Little Colorado River Basin but is considered negligible.

The network of USGS streamflow gages in the study area (table 4) provides fairly complete coverage of streams that have surface discharge from the $\mathrm{C}$ aquifer as base flow. To estimate the base flow outflow component of equation 3 (as part of surface discharge), flow data at gaging stations were analyzed for the months of November through February of each year to eliminate the effects of ET. Minimum monthly mean flows were used to estimate base flow at sites listed in table 4 (Pope and others, 1998). Surface discharge to streams was estimated by multiplying the mean monthly flow for the winter period by 12 to arrive at the annual estimate. It is assumed for the purposes of this evaluation, that the quantity of water estimated as surface discharge to streams, is exiting the control volume. Some surface discharge to the Little Colorado River may actually be recharged to the control volume since areas of base flow along the river occur in intermittent reaches. The quantity of water that may recharge the control volume along the Little Colorado River is unknown but, for the purposes of this evaluation, was considered to be small when compared to the area of the control volume.

Surface discharge to streams from the $\mathrm{C}$ aquifer as base flow occurs south of the Mogollon Rim at Oak, Wet Beaver, West Clear, Carrizo, and Cibecue Creeks. Discharge from Buckhorn, Bear, Beaver Creek, Wet Beaver, Bubbling Pond, Turtle Pond, Bell Rock, Bunker Hill, and Sterling springs is accounted for at gages on Wet Beaver, West Clear, and Oak Creeks (table 5). To the north of the Mogollon Rim, surface discharge to streams from the $\mathrm{C}$ aquifer as base flow occurs at reaches of the Little Colorado River near Winslow and Holbrook, at Chevelon Creek, and at Black Creek (table 4). Other base- flow information was found from previous investigations and included in the total estimate for surface discharge (table 6). The total surface discharge to streams as base flow is about 61,000 acre-ft/yr (tables 6 and 7).

Spring discharge from the $\mathrm{C}$ aquifer is defined as that outflow component of equation 3 (as part of surface discharge) that does not contribute to streamflow and, therefore, is not measured by a streamflow-gaging station. This amount of water is removed from the control volume by ET processes, but is included in this term because many springs have discharge measurements in the published record. In the Little Colorado River Basin, spring discharge at the source is about 3,200 acre-ft/yr; in the Verde and Salt River basins, it is about 81,700 acre-ft/yr (table 6). These values were computed by simply summing the discharge of known springs in the record. Other unmeasured springs exist, but flow from these is considered negligible compared to flow from the known measured sites. Therefore, total spring discharge is about 85,000 acre-ft/yr (table 6). The total surface discharge component of equation 3 , including discharge to streams as base flow and to springs, is equal to 146,000 acre-ft/yr (tables 6 and 7). 
Table 5. Spring discharge from the $\mathrm{C}$ aquifer and limestone aquifers from various data sources, Little Colorado, Verde, and Salt River Basins, Arizona and New Mexico

[SS, sandstone; FM, formation; LS, limestone; ADAPS, U.S. Geological Survey Automated-Data Processing System; GWSI, U.S. Geological Survey Ground-Water Site Inventory. Discharge data are from measurements unless otherwise noted. Dashes indicate no data]

\begin{tabular}{|c|c|c|c|c|c|c|c|}
\hline \multirow{2}{*}{$\begin{array}{c}\text { Spring } \\
\text { identification } \\
\text { number }\end{array}$} & \multirow[b]{2}{*}{ Spring name } & \multicolumn{2}{|c|}{ Discharge } & \multirow[b]{2}{*}{$\begin{array}{c}\text { Date } \\
\text { measured }\end{array}$} & \multirow[b]{2}{*}{$\begin{array}{c}\text { Water-bearing } \\
\text { unit }\end{array}$} & \multirow[b]{2}{*}{ Source of data } & \multirow[b]{2}{*}{ Remarks } \\
\hline & & $\begin{array}{l}\text { Acre-feet } \\
\text { per year }\end{array}$ & $\begin{array}{l}\text { Gallons per } \\
\text { minute }\end{array}$ & & & & \\
\hline \multicolumn{8}{|c|}{ Springs in the Little Colorado River Basin } \\
\hline \multicolumn{8}{|c|}{ Springs that discharge water from the $\mathrm{C}$ aquifer } \\
\hline (A-11-28)04cbd & Unnamed & ${ }^{1} 323$ & 200 & 1985 & Coconino SS & GWSI & Little Colorado River below Lyman Lake area \\
\hline$(\mathrm{A}-12-28) 17 \mathrm{dca}$ & Salado & ${ }^{2} 2,790$ & 1,730 & 1975,1990 & Coconino SS & Salt River Project & Average discharge for 1995 and 1990 \\
\hline$(\mathrm{A}-13-09) 28 \mathrm{abb}$ & Pivot Rock & --- & --- & --- & Kaibab FM & GWSI & \\
\hline$(\mathrm{A}-13-09) 26 \mathrm{ccb}$ & Fortyfour & ${ }^{1} 1.6$ & 1.0 & 1953 & Kaibab FM & GWSI & \\
\hline (A-13-10)18bdb & Long Valley & --- & --- & --- & Kaibab FM & GWSI & \\
\hline (A-14-26)10cdc & Stinking & 29.0 & 18 & 1976 & Kaibab FM & GWSI & Little Colorado River below Zion Reservoir area \\
\hline$(\mathrm{A}-17-17) 22 \mathrm{ccc}$ & Seep at Chevelon Creek & (3) & (3) & 1966 & Coconino SS & McGavock and others (1986) & No discharge noted in report \\
\hline (A-18-16)30dd & Seep at Clear Creek & (3) & (3) & 1966 & Coconino SS & McGavock and others (1986) & No discharge noted in report \\
\hline$(\mathrm{A}-18-16) 31 \mathrm{bbb}$ & Seep at Clear Creek & (3) & (3) & 1966 & Coconino SS & McGavock and others (1986) & No discharge noted in report \\
\hline$(\mathrm{A}-18-10) 02 \mathrm{ccb}$ & Anderson & 0 & 0 & 1978 & Kaibab FM & GWSI & \\
\hline (A-19-08)08cab & Hoxworth & $1,232.3$ & 20 & 1989,1996 & Kaibab FM & GWSI & Average discharge for 1989 and 1996 \\
\hline (A-19-08)10cdd & Newman Canyon & ${ }^{1} .8$ & .5 & 1996 & Kaibab FM & GWSI & \\
\hline$(\mathrm{A}-20-08) 34 \mathrm{cdb}$ & Babbitt & ${ }^{1} 6.5$ & 4.0 & 1959 & Kaibab FM & GWSI & \\
\hline$(\mathrm{A}-20-08) 32 \mathrm{cca}$ & Clark & ${ }^{1} 5.0$ & 3.1 & 1996 & Kaibab FM & GWSI & \\
\hline 09402300 & $\begin{array}{l}\text { Little Colorado River at } \\
\text { the Mouth }\end{array}$ & ${ }^{2} 164,100$ & 101,600 & 1950-93 & $\begin{array}{l}\text { Redwall LS and } \\
\text { Muav LS }\end{array}$ & $\begin{array}{l}\text { Johnson and Sanderson, 1968; } \\
\text { ADAPS }\end{array}$ & $\begin{array}{l}\text { Average discharge of several springs in the lower } \\
\text { reach of the Little Colorado River including the Blue } \\
\text { Springs area. Part or all of spring discharge is from } \\
\text { leakage from the C aquifer }\end{array}$ \\
\hline \multicolumn{8}{|c|}{ Springs in the Verde River Basin (unless otherwise noted) } \\
\hline \multicolumn{8}{|c|}{ Springs that discharge water from the $\mathrm{C}$ aquifer } \\
\hline$(\mathrm{A}-06-23) \mathrm{ac}$ & Alchesay & 14,500 & 8,980 & 1952 & Supai FM & Feth and Hem, 1963 & White River Basin \\
\hline$(\mathrm{A}-11-13) 07 \mathrm{ac}$ & Nappa & 113 & 70 & 1966 & Supai FM & GWSI & Tonto Creek Basin \\
\hline (A-11-13)08cbb & See & ${ }^{1} 1,450$ & 900 & 1966 & Supai FM & GWSI & Tonto Creek Basin \\
\hline (A-11-09)23 & Red Rock & ${ }^{1} 4.8$ & 3.0 & 1946 & Supai FM & Feth and Hem, 1963 & \\
\hline
\end{tabular}

See footnotes at end of table. 
Table 5.Spring discharge from the $\mathrm{C}$ aquifer and limestone aquifers from various data sources, Little Colorado, Verde, and Salt River Basins, Arizona and New Mexico—Continued

\begin{tabular}{|c|c|c|c|c|c|c|c|}
\hline \multirow{2}{*}{$\begin{array}{c}\text { Spring } \\
\text { identification } \\
\text { number }\end{array}$} & \multirow[b]{2}{*}{ Spring name } & \multicolumn{2}{|c|}{ Discharge } & \multirow[b]{2}{*}{$\begin{array}{c}\text { Date } \\
\text { measured }\end{array}$} & \multirow[b]{2}{*}{$\begin{array}{c}\text { Water-bearing } \\
\text { unit }\end{array}$} & \multirow[b]{2}{*}{ Source of data } & \multirow[b]{2}{*}{ Remarks } \\
\hline & & $\begin{array}{l}\text { Acre-feet } \\
\text { per year }\end{array}$ & $\begin{array}{l}\text { Gallons per } \\
\text { minute }\end{array}$ & & & & \\
\hline$(\mathrm{A}-11-14) 35 \mathrm{~d}$ & OW & 2,580 & 3.6 & $1999-2001$ & Supai FM & Hydro Geo Chem, Inc. & $\begin{array}{l}\text { Average discharge for } 1999-2001 \\
\text { Unnamed Spring noted by McGavock and others, } \\
\text { 1968. Discharge reported as 2,080 acre-feet per year }\end{array}$ \\
\hline (A-11-5-09)30 & Oak & 14.8 & 3.0 & 1946 & Supai FM (?) & Feth and Hem, 1963 & \\
\hline (A-12-07)14 & Fossil & 30,000 & 18,600 & 1952 & Naco & $\begin{array}{l}\text { Feth and Hem, 1963; } \\
\text { McGavock and others, } 1968\end{array}$ & $\begin{array}{l}\text { Spring flow gaged at Fossil Creek. Part or all of } \\
\text { spring discharge is leakage from C aquifer }\end{array}$ \\
\hline$(\mathrm{A}-12-08) 23$ & Strawberry & ${ }^{1} 1.6$ & 1.0 & 1946 & Coconino SS & Feth and Hem, 1963 & \\
\hline (A-12-08)26da & Unnamed & ${ }^{1} 1.6$ & 1.0 & 1946 & Supai FM & Feth and Hem, 1963 & \\
\hline$(A-12-08) 26 d a$ & Unnamed & ${ }^{1} 1.6$ & 1.0 & 1946 & Supai FM & Feth and Hem, 1963 & \\
\hline$(\mathrm{A}-12-08) 35 \mathrm{c}$ & Cottonwood & ${ }^{1} 1.6$ & 1.0 & 1946 & Supai FM & Feth and Hem, 1963 & \\
\hline$(\mathrm{A}-12-09) 4 \mathrm{~b}$ & Wildcat & --- & --- & --- & Kaibab & Owen-Joyce and Bell, 1983 & \\
\hline$(\mathrm{A}-12-09) 8$ & Parsnip & ${ }^{1} 16.1$ & 10 & 1946 & Supai FM & Feth and Hem, 1963 & \\
\hline (A-120-9)30dd & Dripping & ${ }^{1} 4.8$ & 3.0 & 1946 & Supai FM & Feth and Hem, 1963 & \\
\hline$(\mathrm{A}-12-10) 11 \mathrm{c}$ & Washington Park & ${ }^{1} 16.1$ & 10 & 1952 & Supai FM & Feth and Hem, 1963 & \\
\hline$(\mathrm{A}-12-10) 14 \mathrm{a}$ & East Verde & $1_{202}$ & 125 & 1952 & Supai FM & Feth and Hem, 1963 & May be gaged as part of East Verde River \\
\hline$(\mathrm{A}-12-10) 34$ & Burned House & ${ }^{1} 161$ & 100 & 1952 & Supai FM & Feth and Hem, 1963 & \\
\hline $\begin{array}{l}(\mathrm{A}-12-12) 32(1) \\
\text { (or 32cdd GWSI) }\end{array}$ & Winters No. 1 & ${ }^{1} 1.6$ & 1.0 & 1952 & Supai FM (?) & Feth and Hem, 1963; GWSI & Tonto Creek Basin \\
\hline$(\mathrm{A}-12-12) 32(2)$ & Winters No. 2 & 13.2 & 2.0 & 1952 & Supai FM (?) & Feth and Hem, 1963 & Tonto Creek Basin \\
\hline$(\mathrm{A}-12-12) 32(3)$ & Winters No. 3 & 32.3 & 20 & 1952 & Supai FM (?) & Feth and Hem, 1963 & Tonto Creek Basin \\
\hline$(\mathrm{A}-12-12) 33 \mathrm{bac}$ & Tonto & 1,450 & 900 & 1952 & Supai FM & McGavock and others (1986) & \\
\hline (A-13-09)23abb & Clover & ${ }^{1} 32.3$ & 20 & 1952 & Kaibab FM & $\begin{array}{l}\text { Feth and Hem, 1963; Owen- } \\
\text { Joyce and Bell, 1983; GWSI }\end{array}$ & $\begin{array}{l}\text { East Verde River Basin } \\
\text { Perched spring }\end{array}$ \\
\hline$(\mathrm{A}-14-08) 32 \mathrm{a}$ & Buckhorn & 1,620 & 1,000 & 1959 & Coconino SS & GWSI & May be gaged as part of West Clear Creek \\
\hline (A-14-09)31ddc & Bear & 162 & 100 & 1959 & Coconino SS & GWSI & May be gaged as part of West Clear Creek \\
\hline (A-15-05)11aab & Beaverhead & 137 & 85 & 1974 & Supai FM & GWSI & May be gaged as part of Wet Beaver Cree \\
\hline$(\mathrm{A}-15-06) 23 \mathrm{bdc}$ & Unnamed & --- & --- & --- & Supai FM & GWSI & \\
\hline (A-15-06)23bdd & Beaver Creek & 3.23 & 20 & 1978 & Supai FM & GWSI & May be gaged as part of Wet Beaver Creek \\
\hline
\end{tabular}


w Table 5.Spring discharge from the $\mathrm{C}$ aquifer and limestone aquifers from various data sources, Little Colorado, Verde, and Salt River Basins, Arizona and New Mexico—Continued

\begin{tabular}{|c|c|c|c|c|c|c|c|}
\hline \multirow{2}{*}{$\begin{array}{c}\text { Spring } \\
\text { identification } \\
\text { number }\end{array}$} & \multirow[b]{2}{*}{ Spring name } & \multicolumn{2}{|c|}{ Discharge } & \multirow[b]{2}{*}{$\begin{array}{l}\text { Date } \\
\text { measured }\end{array}$} & \multirow[b]{2}{*}{$\begin{array}{l}\text { Water-bearing } \\
\text { unit }\end{array}$} & \multirow[b]{2}{*}{ Source of data } & \multirow[b]{2}{*}{ Remarks } \\
\hline & & $\begin{array}{l}\text { Acre-feet } \\
\text { per year }\end{array}$ & $\begin{array}{l}\text { Gallons per } \\
\text { minute }\end{array}$ & & & & \\
\hline$(\mathrm{A}-15-06) 35 \mathrm{cac}$ & Walker Creek & ${ }^{1} 121$ & 75 & 1959 & Coconino SS & GWSI & May be gaged as part of Wet Beaver Creek \\
\hline (A-15-07)14acc & Wet Beaver & $1_{2,180}$ & 1,350 & 1959 & Coconino SS & GWSI & May be gaged as part of Wet Beaver Creek \\
\hline (A-16-04)23bbc & Bubbling Pond & 6,270 & 3,880 & 1968 & Supai FM & GWSI & May be gaged as part of Oak Creek \\
\hline (A-16-04)23dda & Page & 22,400 & 13913 & 1968 & Supai FM & McGavock and others (1986) & \\
\hline (A-16-04)23bba & Turtle Pond & 246 & 152 & 1952 & Supai FM & GWSI & May be gaged as part of Oak Creek \\
\hline (A-16-05)12add & Bell Rock & ${ }^{1} 1.6$ & 1.0 & 1974 & Supai FM & GWSI & May be gaged as part of Oak Creek \\
\hline$(\mathrm{A}-17-03) 17 \mathrm{dbc}$ & Unnamed & 80.7 & 50 & 1965 & Supai FM & GWSI & $\begin{array}{l}\text { Part or all of spring discharge is from leakage from } \mathrm{C} \\
\text { aquifer. Sycamore Creek Basin }\end{array}$ \\
\hline (A-17-02)03aаa & Unnamed & ${ }^{1} 121$ & 75 & 1977 & Supai FM & GWSI & Sycamore Creek Basin \\
\hline (A-18-01)18wbbd & King & --- & --- & --- & Supai FM & GWSI & \\
\hline (A-18-06)5a & Unnamed & ${ }^{1} 1,210$ & 749 & 1949 & Supai FM & Feth and Hem, 1963 & \\
\hline$(\mathrm{A}-18-06) 5 \mathrm{~b}$ & Hummingbird & ${ }^{1} 40.3$ & 25 & 1949 & Supai FM & Feth and Hem, 1963 & $\begin{array}{l}\text { Part or all of spring discharge is from leakage from } \mathrm{C} \\
\text { aquifer }\end{array}$ \\
\hline (A-18-06)5bc & Unamed & ${ }^{1} 80.7$ & 50 & 1949 & Supai FM & Feth and Hem, 1963 & \\
\hline$(\mathrm{A}-180-6) 7 \mathrm{a}$ & Unnamed & $1_{24.2}$ & 15 & 1949 & Supai FM & Feth and Hem, 1963 & \\
\hline$(\mathrm{A}-18-06) 27 \mathrm{ccc}$ & Indian Garden & 186 & 115 & 1952 & Supai FM & Feth and Hem, 1963 & \\
\hline$(\mathrm{A}-18-06) 34 \mathrm{bb}$ & Thompson Pasture & 290 & 180 & 1952 & Supai FM & Feth and Hem, 1963 & \\
\hline (A-19-04)36acc & Bunker Hill & ${ }^{1} 16.1$ & 10 & 1962 & Kaibab FM & GWSI & May be gaged as part of Oak Creek \\
\hline$(\mathrm{A}-19-05) 13 \mathrm{cc}$ & Unnamed & ${ }^{1} 1.6$ & 1.0 & 1949 & Coconino SS & Feth and Hem, 1963 & \\
\hline$(\mathrm{A}-19-05) 30 \mathrm{c}$ & Barney & .20 & .12 & 1949 & Coconino SS & Feth and Hem, 1963 & \\
\hline$(A-19-06) 15 d(2)$ & Unnamed & 33.9 & 21 & 1949 & Coconino SS & Feth and Hem, 1963 & \\
\hline$(A-19-06) 15 d(3)$ & No. 3 in Oak Creek & $1_{24.2}$ & 15 & 1949 & Coconino SS & Feth and Hem, 1963 & \\
\hline (A-19-06)15ddd1 & Sterling & 468 & 291 & 1949 & Coconino SS & GWSI & \\
\hline (A-19-6)5ddd2 & Sterling & 33.8 & 20.9 & 1949 & Coconino SS & GWSI & \\
\hline (A-19-06)15ddd3 & Sterling & ${ }^{1} 32.3$ & 20 & 1949 & Coconino SS & GWSI & \\
\hline$(\mathrm{A}-19-06) 22 \mathrm{~d}$ & Unamed & 294 & 182 & 1949 & Coconino SS & Feth and Hem, 1963 & \\
\hline$(\mathrm{A}-19-06) 34 \mathrm{c}$ & LeLani & $1_{48}$ & 29.7 & 1949 & Supai FM & Feth and Hem, 1963 & \\
\hline
\end{tabular}


Table 5.Spring discharge from the $\mathrm{C}$ aquifer and limestone aquifers from various data sources, Little Colorado, Verde, and Salt River Basins, Arizona and New Mexico—Continued

\begin{tabular}{|c|c|c|c|c|c|c|c|}
\hline \multirow{2}{*}{$\begin{array}{c}\text { Spring } \\
\text { identification } \\
\text { number }\end{array}$} & \multirow[b]{2}{*}{ Spring name } & \multicolumn{2}{|c|}{ Discharge } & \multirow[b]{2}{*}{$\begin{array}{c}\text { Date } \\
\text { measured }\end{array}$} & \multirow[b]{2}{*}{$\begin{array}{c}\text { Water-bearing } \\
\text { unit }\end{array}$} & \multirow[b]{2}{*}{ Source of data } & \multirow[b]{2}{*}{ Remarks } \\
\hline & & $\begin{array}{l}\text { Acre-feet } \\
\text { per year }\end{array}$ & $\begin{array}{l}\text { Gallons per } \\
\text { minute }\end{array}$ & & & & \\
\hline (A-19-06)34wc2 & Hummingbird & ${ }^{1} 40.3$ & 25 & 1949 & Supai FM & GWSI & \\
\hline (A-19-06)34wc1 & Sherwood & ${ }^{1} 80.7$ & 50 & 1949 & Supai FM & GWSI & \\
\hline (A-19-06)34wa & Lolami & ${ }^{1} 40.3$ & 25 & 1949 & Supai FM & GWSI & \\
\hline (A-19-06)27ebcc & Grassy Meadow & ${ }^{1} 1.6$ & 1.0 & 1949 & Supai FM & GWSI & \\
\hline (A-19-05)24ccc & Buzzard & ${ }^{1} 3.2$ & 2.0 & 1962 & Kaibab FM & GWSI & \\
\hline (A-20-04)35abd & Babes Hole & .8 & .5 & --- & Kaibab FM & GWSI & \\
\hline \multicolumn{8}{|c|}{ Springs that discharge water from limestone aquifers below the $\mathrm{C}$ aquifer } \\
\hline$(\mathrm{A}-11-12) 20$ & Indian Gardens & --- & --- & 1952 & Redwall LS & Feth and Hem, 1963 & \\
\hline (A-11-12)20dab & Indian Gardens & 161 & 100 & 1952 & Redwall LS & GWSI & \\
\hline$(\mathrm{A}-11-10) 4 \mathrm{c}$ & Webber Canyon & 2,100 & 1,300 & 1952 & Redwall LS & Feth and Hem, 1963 & \\
\hline$(\mathrm{A}-11-10) 9 \mathrm{~b}$ & Grotto & 565 & 350 & 1952 & Martin FM & Feth and Hem, 1963 & $\begin{array}{l}\text { Part or all of spring discharge is from leakage from } \mathrm{C} \\
\text { aquifer }\end{array}$ \\
\hline$(\mathrm{A}-11-11) 13 \mathrm{dcc}$ & Wildcat (Arsenic) & ${ }^{1} 8.1$ & 5.0 & 1952 & Martin FM & Feth and Hem, 1963 & $\begin{array}{l}\text { Part or all of spring discharge is from leakage from } \mathrm{C} \\
\text { aquifer }\end{array}$ \\
\hline (A-11-12)16bac & Henterkey & 96.8 & 60 & 1952 & Martin FM & Feth and Hem, 1963 & \\
\hline$(\mathrm{A}-11-5-09) 30 \mathrm{dc}$ & Cold & 6,780 & 4,200 & 1952 & Martin FM & Feth and Hem, 1963 & \\
\hline$(A-17-03) 05 d$ & Summers & 4,360 & 2,700 & 1951 & Redwall LS & GWSI & Average discharge for 1952 \\
\hline$(\mathrm{A}-17-03) 05 \mathrm{c}$ & Unnamed & $1_{24.2}$ & 15 & 1951 & Redwall LS & GWSI & \\
\hline$(\mathrm{A}-18-03) 32 \mathrm{a}$ & Parson & ${ }^{1} 1,610$ & 1,000 & 1951 & Redwall LS & GWSI & $\begin{array}{l}\text { Part or all of spring discharge is from leakage from } \mathrm{C} \\
\text { aquifer }\end{array}$ \\
\hline 09505260 & Montezuma Well & 1,480 & 916 & 1990 & Redwall LS & ADAPS & $\begin{array}{l}\text { Part or all of spring discharge is from leakage from } \mathrm{C} \\
\text { aquifer }\end{array}$ \\
\hline
\end{tabular}

$$
\begin{aligned}
& { }^{1} \text { Estimated. } \\
& { }^{2} \text { Average. } \\
& { }^{3} \text { Seep. }
\end{aligned}
$$


Table 6. Summary of spring discharge by basin as base flow, at spring source, or as downward leakage from the $\mathrm{C}$ aquifer, Little Colorado River Basin and parts of the Verde and Salt River Basins, Arizona and New Mexico

\begin{tabular}{|c|c|}
\hline Ground-water budget component & Discharge, in acre-feet per year \\
\hline \multicolumn{2}{|c|}{ Little Colorado River Basin } \\
\hline \multicolumn{2}{|l|}{ Spring discharge as base flow: } \\
\hline Little Colorado River near Woodruff & ${ }^{1} 1,950$ \\
\hline Chevelon Creek near Winslow & ${ }^{1} 1,950$ \\
\hline Black Creek near Lupton & ${ }^{1} 41.6$ \\
\hline Little Colorado River at Holbrook & 2,590 \\
\hline Total base flow & 6,532 \\
\hline \multicolumn{2}{|l|}{ Spring discharge at source: } \\
\hline Unnamed spring (below Lyman Lake) & 2323 \\
\hline Salado Spring & 22,790 \\
\hline Fortyfour Spring & ${ }^{2} 1.6$ \\
\hline Stinking Spring & ${ }^{2} 29$ \\
\hline Hoxworth Spring & 232 \\
\hline Newman Canyon Spring & ${ }^{2} 0.8$ \\
\hline Babbitt Spring & ${ }^{2} 6.5$ \\
\hline Clark Spring & 25.0 \\
\hline Total at source & $3,188.2$ \\
\hline \multicolumn{2}{|l|}{ Downward leakage: } \\
\hline Little Colorado River, Blue Springs Vicinity & 2164,100 \\
\hline Total, Little Colorado River Basin & 173,820 \\
\hline
\end{tabular}

Verde and Salt River Basins

Spring discharge as base flow:

Sycamore Creek at mouth

${ }^{3} 6,140$

Oak Creek near Cornville

$1_{21,140}$

Wet Beaver Creek near Rimrock

14,570

West Clear Creek near Camp Verde

${ }^{1} 11,200$

Carrizo Creek near Show Low

${ }^{1} 3,270$

Cibicue Creek near Chrysotile

${ }^{1} 7,610$

East Verde River near Pine

1452

Webber Creek above West Fork Webber Creek near Pine

1293

Total base flow

54,675

Spring discharge at source:

Dry Beaver Spring

${ }^{4} 150$

Alchesay Spring

214,500

Nappa Spring

${ }^{2} 113$

See Spring

Red Rock Spring

${ }^{2} 1,450$

Oak Spring

OW Spring

24.8

Fossil Spring

Strawberry

Unnamed Spring

Cottonwood Spring

$2,580.0$

Parsnip Spring

Burned House

Winters No. 1

${ }^{4} 33,800$

${ }^{2} 1.6$

21.6

21.6

${ }^{2} 16.1$

${ }^{2} 161$

${ }^{2} 1.6$

See footnotes at end of table. 
Table 6. Summary of spring discharge by basin as base flow, at spring source, or as downward leakage from the $\mathrm{C}$ aquifer, Little Colorado River Basin and parts of the Verde and Salt River Basins, Arizona and New Mexico-Continued

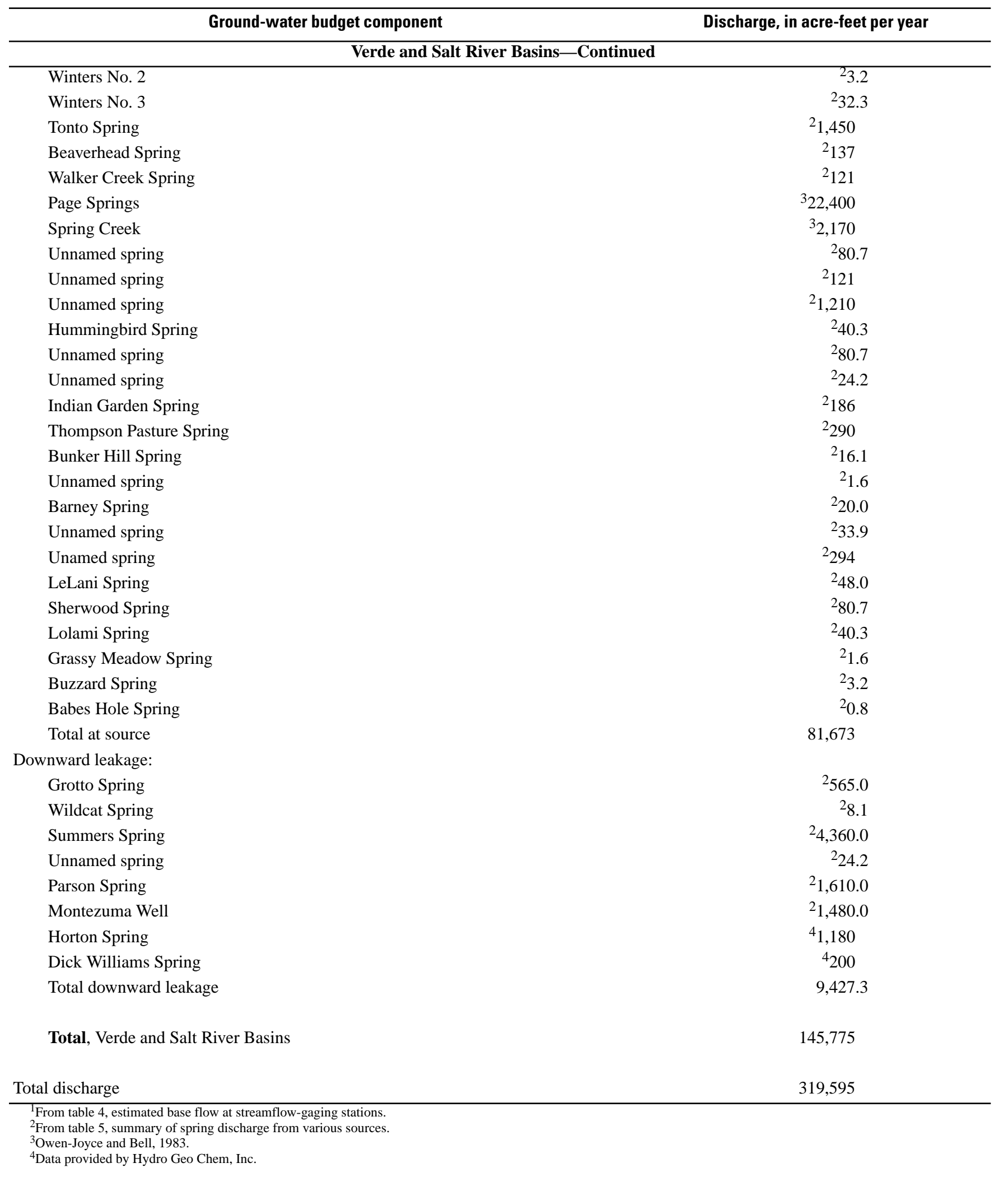


Table 7. Summary of annual ground-water budget components for the $\mathrm{C}$ aquifer, Little Colorado River Basin and parts of the Verde and Salt River Basins, Arizona and New Mexico

[Values are in acre-feet per year rounded to the nearest 1,000.]

\begin{tabular}{lc}
\hline \multicolumn{1}{c}{ Ground-water budget component } & Discharge value \\
\hline Spring discharge to streams as base flow & 61,000 \\
$\begin{array}{l}\text { Spring discharge not accounted for by } \\
\text { base flow }\end{array}$ & 85,000 \\
Downward leakage: & \\
$\quad$ Blue springs area & 0 \\
Other springs & 164,000 \\
Evapotranspiration & \\
Underflow & \\
Total discharge $^{2}$ & 0 \\
Total recharge & 319,000 \\
\hline
\end{tabular}

${ }^{1}$ All evapotranspiration is assumed to be from evaporation of streamflow or transpiration by riparian vegetation. Consequently, evapotranspiration was accounted for by adjusting the base-flow discharge component.

${ }^{2}$ Component could not be estimated but is assumed to be insignificant for the purposes of the ground-water budget.

${ }^{3}$ Assuming steady-state conditions. No attempt was made to resolve the various recharge components.

Downward leakage to the underlying Redwall and Muav Limestones and other water-bearing units including the Naco and Martin Formations is considered to be the other major discharge component of equation 3 (fig. 10). Because of the physical boundaries of the control volume, it is assumed that all discharge from the Redwall and Muav Limestones and the Naco and Martin Formations is leakage from the $\mathrm{C}$ aquifer. No outcrops of these rock units are exposed to intercept precipitation. Precambrian granites underlie the Redwall-Muav aquifer south of the Mogollon Rim, and the Bright Angel Shale of Cambrian age underlies the aquifer in the northwestern part of the study area. Both rock units are considered to be relatively impermeable, thereby preventing downward leakage from the aquifer (fig. 10).

The numerous springs, therefore, including Blue Springs, in the lower 13 miles of the Little Colorado River are assumed to be the primary points of ground-water discharge from the control volume that represents downward leakage. Discharge at these springs was determined from reports by previous investigators and recent measurements by the USGS (table 5). North of the Mogollon rim, discharge from downward leakage occurs primarily in the Blue Springs area and is about 164,000 acre-ft/yr (tables 5 and 6). South of the Mogollon Rim toward the Verde and Salt River Basins, discharge from downward leakage at springs is about 9,000 acre- $\mathrm{ft} / \mathrm{yr}$ (tables 6 and 7). This discharge includes Grotto, Wildcat, Summers, Parson, and Montezuma's Well springs, and an unnamed spring. Other springs issuing from the limestone aquifers include Cold, Henturkey, Webber Canyon, and Indian Gardens (table 5), but their source of water is not believed to be leakage from the C aquifer (John Ward, Hydro Geo Chem, Inc., written commun., 2001). On the basis of these discharge measurements, total downward leakage from the $\mathrm{C}$ aquifer is estimated to be 173,000 acre-ft/yr (table 7).

The ET component of equation 3 is the amount of water lost to the atmosphere by (1) evaporation from the water table, (2) transpiration by plants that withdraw water from the saturated zone, and (3) evaporation from base flow in streams of which base flow is sustained by discharge from the $\mathrm{C}$ aquifer. Even after summing all three terms, the amount of water lost to ET is negligible; therefore, the term is dropped. The underflow component of equation 3 is zero because of the physical boundaries and the defined control volume of the $\mathrm{C}$ aquifer (fig. 11).

When the estimates of the individual components are substituted into equation 3, total outflow from the $\mathrm{C}$ aquifer becomes 319,000 acre-ft/yr (table 7). If the ground-water flow system is in equilibrium, then the recharge to the $\mathrm{C}$ aquifer also is about $319,000 \mathrm{acre}-\mathrm{ft} / \mathrm{yr}$.

Water budgets of ground-water systems such as the $\mathrm{C}$ aquifer are inherently uncertain because many of the flow quantities cannot be observed or measured directly. For this analysis, some outflow quantities were derived from records of stream gages and from measured spring flow. Other quantities were estimated. Data-collection efforts that would most readily reduce uncertainty in this budget include additional gaging of base flow in streams and additional measurement of spring flow. 


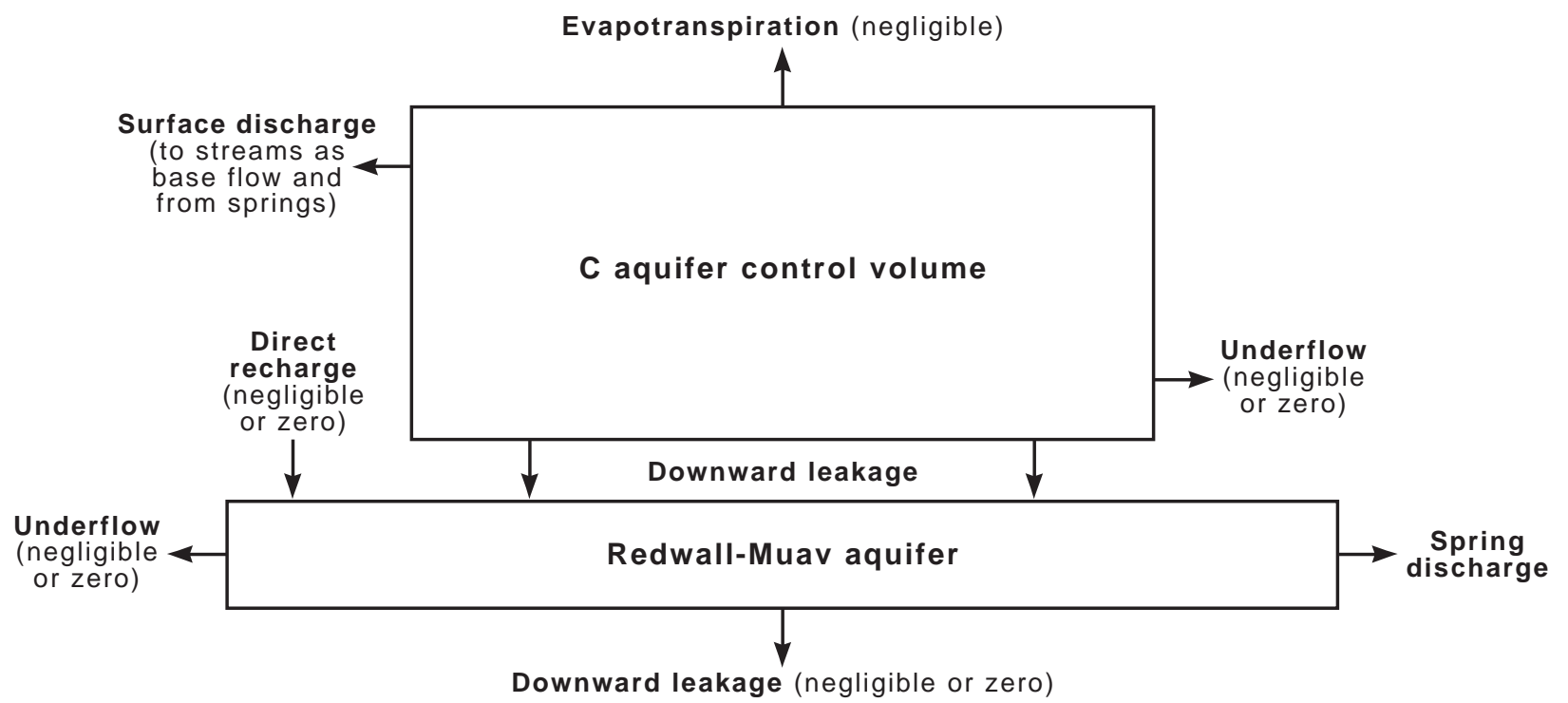

Figure 11. Schematic representation of the outflow components of the $C$ aquifer and the interaction of the aquifer with the underlying Redwall-Muav aquifer. Evapotranspiration, underflow from the $C$ and Redwall-Muav aquifers, and downward leakage are all considered negligible.

\section{CONSIDERATIONS FOR ADDITIONAL DATA COLLECTION AND MONITORING}

In the Little Colorado River Basin, gaps in hydrologic data hampered quantifying ground-water budget components for the $\mathrm{C}$ aquifer. In the Black Mesa area, ground-water data are sparse for the $\mathrm{C}$ aquifer; therefore, inferences had to be made for some components. For example, depth to ground water and movement of ground water in both the $\mathrm{C}$ aquifer and the underlying Redwall-Muav Limestone aquifer are based on few data points; therefore, potentiometric contour lines cannot be drawn through the Black Mesa area with any confidence (fig. 9). Because of the great depths to the $\mathrm{C}$ aquifer in the Black Mesa area, installation of additional monitoring wells would be expensive. Geophysical instruments capable of penetrating these depths may be a feasible way of investigating the aquifer in further detail. Some wells located at NPS park units within the Little Colorado River Basin are currently being monitored by the USGS in cooperation with the NPS. The ADWR periodically measures wells in the study area as part of its monitoring program. Also, some private industries such as Tucson Electric Power and the Salt River Project monitor their wells and provide results to the State of Arizona.

Many springs in the $\mathrm{C}$ aquifer have not been measured since the 1950s, and some springs have not been inventoried. Most large springs in the area are known and have some history of discharge measurements associated with them. Because the $\mathrm{C}$ aquifer has a direct effect on surface-water resources in the basin, indicator springs could be equipped with recording instruments to monitor spring discharge and to show when natural or human-caused stresses begin to affect flow at those sites. Indicator springs could include those in the lower Little Colorado River (Blue Springs vicinity), those in the central part of the basin near St. Johns, and some that discharge to the south along the Mogollon Rim.

The potentiometric surface of the $\mathrm{C}$ aquifer shown in figure 9 is based on previous work by Mann (1976), Levings and Farrar (1977a, b), Ross (1977), Denis (1979), Appel and Bills (1980, 1981), Loughlin (1983), Mann and Nemecek (1983), Owen-Joyce and Bell (1983), McGavock and others (1986), Orr (1987), and Baldwin and Rankin (1995) for 1972-85 and does not 
represent current conditions. Several national monuments and parks in the basin have wells that are developed in the $\mathrm{C}$ aquifer, and most of these wells are currently being measured by the USGS. The ADWR may have recent water-level information for many wells in the study area that could be used to map the current potentiometric surface in parts of the study area where wells exist.

Geochemical methods were used in previous studies in the basin to determine the age of ground water. This data could be analyzed to determine the areal extent of its coverage and to identify areas where additional data collection and analysis would be beneficial. A geochemical approach can provide data for delineation of recharge areas and for improving estimates of rates of recharge, residence time of ground water, and rates of ground-water movement.

Because ground-water data are scarce, particularly in the Black Mesa area, a predictive regional groundwater flow model based on presently available data may not be reliable. Models have been developed for selected areas within the basin where data coverage is more complete. Development of an interpretive ground-water flow model on the basis of newly acquired data may be feasible for the entire basin and would provide additional information on the interrelations of ground-water budget components for the $\mathrm{C}$ aquifer.

\section{SUMMARY}

The $\mathrm{C}$ aquifer is the most extensive and productive aquifer in the Little Colorado River Basin and parts of the Verde and Salt River Basins and is named for the primary water-bearing rock unit of the aquifer, the Coconino Sandstone. Other rock units of the $\mathrm{C}$ aquifer include the Kaibab Formation and the Upper Supai Formation. The aquifer underlies the entire surfacewater drainage of the Little Colorado River.

Data on the $\mathrm{C}$ aquifer in the basin are primarily in databases of the USGS and other Federal, State, and tribal water-resource agencies. More than 1,000 well and spring sites were identified in the USGS databases for Arizona and New Mexico. Data are sparse or nonexistent in areas of the basin where the $\mathrm{C}$ aquifer is deeply buried by overlying geologic units. Well and stream data are more plentiful for the area south of the Little Colorado River and north of the Mogollon slope.
Many reports have been written and published on the hydrology and geology of the basin. The greatest amount of information available is related to geology.

The $\mathrm{C}$ aquifer is one of several aquifers in the basin. Shallow ground water occurs in alluvial sediments along streams and in volcanic rocks. Aquifers along the Mogollon Rim, such as the PinetopLakeside and White Mountain aquifers, provide water to several communities in the area. In the Black Mesa area, the $\mathrm{D}$ and $\mathrm{N}$ aquifers overlie the $\mathrm{C}$ aquifer and are not connected hydraulically to the $\mathrm{C}$ aquifer. The Redwall-Muav Limestone aquifer underlies and may be hydraulically connected to the $\mathrm{C}$ aquifer throughout much of the basin.

Prior to the 1940s, ground-water development in the basin was minimal. Ground-water development has increased since then in response to increasing industrial, agricultural, and municipal water uses. Some parts of the basin, such as in the south-central area where industrial development is concentrated, show greater effects from ground-water withdrawal than other parts. Areas such as Black Mesa have had little development because of the expense of drilling deep wells to reach the aquifer and costs of pumping water from such extreme depths. Ground-water pumpage from the $\mathrm{C}$ aquifer during 1995 was about 140,000 acre-ft.

The $\mathrm{C}$ aquifer is connected hydraulically to some reaches of the Little Colorado River and Chevelon, East Clear, Oak, Wet Beaver, Carrizo, and Cibecue Creeks. The potential for stream-aquifer interaction (flow into and out of the aquifer) depends on the characteristics of the rock units that make up the stream channel and on the ground-water level. Excessive ground-water pumping or drought conditions that cause ground-water levels to decline can reduce base flow in streams that have direct contact with rock units of the $\mathrm{C}$ aquifer.

Ground-water budget components for the $\mathrm{C}$ aquifer were evaluated and estimated using existing information. The ground-water budget analysis helped to identify data deficiencies and areas where collection of new data is needed. Downward leakage from the $\mathrm{C}$ aquifer to limestones accounts for most of the total discharge in the estimated ground-water budget for the $\mathrm{C}$ aquifer. Discharge from the $\mathrm{C}$ aquifer under steadystate conditions is estimated to be 319,000 acre-ft/yr. For this analysis, the total recharge to the $\mathrm{C}$ aquifer is assumed to be equal to the total discharge from the aquifer. 


\section{SELECTED REFERENCES}

Akers, J.P., 1962, Relation of faulting to the occurrence of ground water in the Flagstaff area, Arizona, in Geological Survey Research, 1962, Short Papers in Geology, Hydrology and Topography, Articles 1-59: U.S. Geological Survey Professional Paper 450-B, article 39, p. B97-B100.

1964, Geology and ground-water in the central part of Apache County, Arizona: U.S. Geological Survey Water-Supply Paper 1771, $107 \mathrm{p}$.

Anderson, O.J., Jones, G.E., and Green, G.N., 1962, Geologic map of New Mexico: U.S. Geological Survey Open-File Report 97-62, 1 sheet.

Anning, D.W., and Duet, N.R., 1994, Summary of groundwater conditions in Arizona,1987-90: U.S. Geological Survey Open-File Report 94-476, 1 sheet.

Appel, C.L., and Bills, D.J., 1980, Map showing groundwater conditions in the Canyon Diablo area, Coconino and Navajo Counties, Arizona, 1979: U.S. Geological Survey Open-File Report 80-747, scale 1:125,000.

1981, Maps showing ground-water conditions in the San Francisco Peaks area, Coconino County, Arizona1979: U.S. Geological Survey Open-File Report 81-914, scale 1:125,000.

Arizona Department of Water Resources, 1994a, Arizona water-resources assessment, Volume I, Inventory and analysis: Phoenix, Arizona Department of Water Resources, 253 p.

1994b, Arizona water-resources assessment, Volume II, Hydrologic Summary: Phoenix, Arizona Department of Water Resources, 236 p.

1999, Overview of Arizona's Groundwater Management Code: accessed December 15, 1999, at URL http://www.adwr.state.az.us/AZWaterInfo/ groundwater/code.html.

Baars, D.L., 1962, Permian system of Colorado Plateau: American Association of Petroleum Geologists Bulletin, v. 46, no. 2, p. 149-218.

Baldwin, J.A., and Rankin, D.R., 1995, Hydrogeology of Cibola County, New Mexico: U.S. Geological Survey Water-Resources Investigations Report 94-4178, 102 p.

Baldys, Stanley, III, and Bayles, J.A., 1990, Flow characteristics of streams that drain the Fort Apache and San Carlos Indian Reservations, east-central Arizona, 1930-86, U.S. Geological Survey WaterResources Investigations Report 90-4053, 59 p.

Beus, S.S., 1989, Devonian and Mississippian geology of Arizona: Tucson, Arizona Geological Society Digest 17, p. 287-311.

1990, Redwall Limestone and Surprise Canyon Formation, Grand Canyon Geology: New York, Oxford University Press, p. 119-145
Bills, D.J., and Hjalmarson, H.W., 1990, Estimates of ground-water flow components for Lyman Lake, Apache County, Arizona, with a section on Geochemistry of surface water and ground water in the Lyman Lake area, by F.N. Robertson: U.S. Geological Survey Water-Resources Investigations Report 89-4151, 55 p.

Bills, D.J., Truini, Margot, Flynn, M.E., Pierce, H.A., Catchings, R.D., and Rhymer, M.J., 2000, Hydrogeology of the regional aquifer near Flagstaff, Arizona, 1994-97: U.S. Geological Survey WaterResources Investigations Report 00-4122, 143 p.

Billingsley, G.H., Breed, W.J., and Beasley, D., 1980, Geologic cross sections along Interstate 40-Kingman to Flagstaff, Arizona: Chandler, Arizona, Pagosa Press, Petrified Forest Museum Association in cooperation with Museum of Northern Arizona, map sheet.

Blakey, R.C., 1979, Lower Permian stratigraphy of the southern Colorado Plateau-Permianland: Four Corners Geological Society, Ninth Field Conference Guidebook, p. 179-186.

1989, Triassic and Jurassic geology of the southern Coconino Plateau: Tucson, Arizona Geological Society Digest 17, p. 369-396.

1990, Stratigraphy and geologic history of Pennsylvanian and Permian rocks, Mogollon Rim region, central Arizona and vicinity: Geological Society of America Bulletin, v. 102, no. 9, p. 1189-1217.

Blakey, R.C., and Knepp, R., 1989, Pennsylvanian and Permian geology of Arizona, in Jenney, J.P., and Reynolds, S.J., eds., Geologic Evolution of Arizona: Arizona Geological Society Digest 17, p. 313-347.

Bouwer, Herman, 1978, Groundwater hydrology: New York, McGraw-Hill, Inc., 480 p.

Brown, D.E., Carmony, N.B., and Turner, R.M., 1978, Drainage map of Arizona showing perennial streams and some important wetlands: Phoenix, Arizona Game and Fish Department unnumbered map report, 1 sheet.

Christensen, P.K., 1980, Sunset Crater well no. 2, Sunset Crater National Monument, Arizona: Phoenix, Arizona, National Park Service Water Resources Report 80-7, $38 \mathrm{p}$.

Cooley, M.E., 1963, Hydrology of the Plateau uplands province, in White, N.D., Stulik, R.S., Morse, E.K., and others, Annual report on ground water in Arizona, spring 1962 to spring 1963: Phoenix, Arizona State Land Department, Water Resources Report 15, p. 27-38.

1976, Spring flow from pre-Pennsylvanian rocks in the southwestern part of the Navajo Indian Reservation, Arizona: U.S. Geological Survey Professional Paper 521-F, 15 p. 
Cooley, M.E., Harshbarger, J.W., Akers, J.P., and Hardt, W.F., 1969, Regional hydrogeology of the Navajo and Hopi Indian Reservations, Arizona, New Mexico, and Utah, with a section on Vegetation by O.N. Hicks: U.S. Geological Survey Professional Paper 521-A, 61 p.

Crouch, T.M., 1994, Hydrogeology and aquifer test of the San Andres-Glorieta aquifer on the southwest part of the Zuni Indian Reservation, Cibola County, New Mexico: U.S. Geological Survey Water-Resources Investigations Report 94-4033, $36 \mathrm{p}$.

Dane, C.H., and Bachman, G.O., 1965, Geologic map of New Mexico: U.S. Geological Survey, scale, 1:500,000, 2 sheets.

Darton, N.H., 1910, A reconnaissance of parts of northwestern New Mexico and northern Arizona, U.S. Geological Survey Bulletin 435, 88 p.

Denis, E.E., 1979, Map showing ground-water conditions in the Tonto Basin area, Gila County, Arizona-1979: U.S. Geological Survey Water-Resources Investigations Open-File Report 82-116, 1 sheet.

Driscoll, F.G., 1986, Groundwater and wells, 2nd ed.: St. Paul, Minnesota, Johnson Division, 1089 p.

Elston, D.P., and DiPaolo, W.D., 1979, PennsylvanianPermian stratigraphy in the Sedona area and environs, central and northern Arizona, in Baars, D.L., ed., Permianland: Four Corners Geological Society, Ninth Field Conference Guidebook, p. 131-141.

Elston, D.P., and Young, R.A., 1989, Development of Cenozoic landscape of central and northern ArizonaCutting of Grand Canyon, in Elston, D.P., Billingsley, G.H., and Young, R.A., eds., Geology of Grand Canyon, northern Arizona (with Colorado River guides): Washington, D.C., American Geophysical Union, 28th International Geological Congress, Field Trip Guidebook T115/315, p. 145-153.

Fenneman, N.M., 1946, Physical divisions of the United States: U.S. Geological Survey map, scale 1:700,000.

Feth, J.H., 1954, Preliminary report of investigations of springs in the Mogollon Rim region, Arizona, with sections on A study of perennial base flow in major south-flowing streams in the Mogollon Rim region by N.D. White and Quality of water by J.D. Hem: U.S. Geological Survey unnumbered open-file report, $77 \mathrm{p}$.

Feth, J.H., and Hem, J.D., 1963, Reconnaissance of headwater springs in the Gila River drainage basin, Arizona: U.S. Geological Survey Water-Supply Paper 1619-H, 54 p.

Gallaher, B.M., and Cary, S.J., 1986, Impacts of uranium mining on surface and shallow ground waters, Grants Mineral Belt, New Mexico: Santa Fe, New Mexico Environmental Improvement Division Report, EID/GWH-86/2, 152 p.
Green, G.N., and Jones, G.E., 1997, The digital geologic map of New Mexico in ARC/INFO format: U.S. Geological Survey Open-File Report 97-0052, 9 p.

Gregory, H.E., 1916, The Navajo country-A geographic and hydrographic reconnaissance of parts of Arizona, New Mexico, and Utah: U.S. Geological Survey WaterSupply Paper 380, 219 p.

1917, Geology of the Navajo country-A reconnaissance of parts of Arizona, New Mexico, and Utah: U.S. Geological Survey Professional Paper 93, $161 \mathrm{p}$.

Hackman, R.J., and Olson, A.B., 1977, Geology, structure, and uranium deposits of the Gallup $1^{\circ} \times 2^{\circ}$ quadrangle, New Mexico and Arizona: U.S. Geological Survey Miscellaneous Investigations Series Map I-981, 2 sheets.

Harrel, M.A., and Eckel, E.B., 1939, Ground-water resources of the Holbrook region, Arizona: U.S. Geological Survey Water-Supply Paper 836-B, 86 p.

Haynes, D.D., and Hackman, R.J., 1978, Geology, structure, and uranium deposits of the Marble Canyon $1^{\circ} \times 2^{\circ}$ quadrangle, Arizona: U.S. Geological Survey Miscellaneous Investigations Series Map I-1003, 2 sheets.

Hereford, Richard, and Webb, R.H., 1992, Historic variation of warm-season rainfall, southern Colorado Plateau, southwestern U.S.A.: Amsterdam, The Netherlands, Kluwer Academic Publishers, Climatic Change 22, p. 239-256.

Hintze, L.F., 1973, Geologic history of Utah: Salt Lake City, Utah, Brigham Young University Research Studies, Geology Series, v. 20, no. 8, 181 p.

Huddle, J.W., and Dobrovolny, Ernest., 1952, Devonian and Mississippian rocks of central Arizona, in Shorter Contributions to General Geology, 1950-1951: U.S. Geological Survey Professional Paper 233-D, p. 67-112.

Huntoon, P.W., 1981, Fault-controlled ground-water circulation under the Colorado River, Marble Canyon, Arizona: Ground Water, v. 19, no. 1, p. 20-27.

1986, Ground-water flow directions in Colorado Plateau breccia pipes: Geological Society of America, Abstracts with Programs, v. 18, no. 5, p. 363.

Hydro Geo Chem, Inc., 1991, Results of the hydrogeologic and geochemical investigation for the Little Colorado River Basin, v. 1-Hydrogeologic framework, parameter estimation and modeling results, volume 2Geochemical Characterization: Tucson, Arizona, Hydro Geo Chem report prepared for Bureau of Indian Affairs, $181 \mathrm{p}$.

Irwin, J.H., Steven, P.R., and Cooley, M.E., 1971, Geology of the Paleozoic rocks, Navajo and Hopi Indian Reservations, Arizona, New Mexico, and Utah: U.S. Geological Survey Professional Paper 521-C, 32 p. 
Johnson, P.W., and Sanderson, R.B., 1968, Spring flow into the Colorado River-Lees Ferry to Lake Mead, Arizona: Arizona State Land Department, WaterResources Report Number 34, 26 p.

Levings, G.W., and Farrar, C.D., 1977a, Maps showing ground-water conditions in the southern part of the Chinle area, Apache County, Arizona-1976: U.S. Geological Survey, Water-Resources Investigations Report 77-50, 2 sheets.

1977b, Maps showing ground-water conditions in the northern part of the Chinle area, Apache County, Arizona-1976: U.S. Geological Survey,

Water-Resources Investigations Report 77-35, 2 sheets.

Loughlin, W.D., 1983, The hydrogeologic controls on water quality, ground-water circulation, and collapse breccia pipe formation in the western part of the Black Mesa hydrologic basin, Coconino County, Arizona: Laramie, Wyoming, University of Wyoming, masters thesis, $118 \mathrm{p}$.

McGavock, E.H., 1968, Basic ground-water data for southern Coconino County, Arizona: Arizona State Land Department, Water-Resources Report Number 33, $49 \mathrm{p}$.

McGavock, E.H., Anderson, T.W., Moosburner, Otto, and Mann, L.J., 1986, Water resources of southern Coconino County, Arizona: Arizona Department of Water Resources Bulletin 4, 53 p.

McKee, E.D., 1938, The environment and history of the Toroweap and Kaibab Formations of northern Arizona and southern Utah: Carnegie Institution of Washington Publication 492, 268 p.

1945, Cambrian history of the Grand Canyon region: Carnegie Institution of Washington Publication 563 , pt. 1, p. 1-170.

1949, Facies changes in the Colorado Plateau, in Sedimentary Facies in Geologic History: Geologic Society of America Memoir 39, p. 35-48.

1951, Triassic deposits of the Arizona-New Mexico border area, in Smith, C.T., ed., Guidebook of the south and west sides of the San Juan Basin, New Mexico and Arizona: Santa Fe, New Mexico Geological Society, Second Field Conference Guide Guidebook, p. 85-92. 1963, Nomenclature for lithologic subdivisions of the Mississippian Redwall Limestone, Arizona: U.S. Geological Survey Professional Paper 475-C, p. C21-C22.

1982, The Supai Group of the Grand Canyon: U.S. Geological Survey Professional Paper 1173, 504 p.

McKee, E.D., and Gutschick, R.C., 1969, History of the Redwall Limestone of Northern Arizona: Geological Society of America Memoir 114, chap. 14, p. 553-570.

Mann, L.J., 1976, Ground-water resources and water use in southern Navajo County, Arizona: Arizona Water Commission Bulletin 10, 106 p.
1979, Water budget and mathematical model of the C aquifer, southern Navajo County, Arizona: U.S. Geological Survey Open-File Report 79-348, 58 p.

Mann, L.J., and Nemecek, E.A., 1983, Geohydrology and water use in southern Apache County, Arizona: Phoenix, Arizona Department of Water Resources Bulletin 1, 86 p.

Montgomery, J.M., Consulting Engineers, Inc., 1982, Results of Redwall-Martin testing program at Lake Mary well No. 8: Flagstaff, Arizona, James M. Montgomery Consulting Engineers, Inc., report to the City of Flagstaff, Arizona Utilities Department, 10 p.

Montgomery, Errol, L., and Associates, 1993a, Projections for composite drawdown impact for the Kaibab-C aquifer based on revised projected groundwater withdrawals for the Springerville and Coronado Generating Stations, Apache County, Arizona: Tucson, Arizona, Errol L. Montgomery and Associates, Inc., $14 \mathrm{p}$.

1993b, Results of 90-day aquifer test and groundwater-flow model projections for long-term groundwater yield for the Coconino-Supai aquifer, Lake Mary well field, Coconino County, Arizona: Tucson, Arizona, Errol L. Montgomery and Associates, Inc., 53 p.

1996, Assessment of hydrogeologic conditions and potential effects of proposed groundwater withdrawal for Canyon Forest Village, Coconino County, Arizona: Tucson, Arizona, Errol L. Montgomery and Associates, Inc., 64 p.

Moore, R.T., and Peirce, H.W., 1967, Geologic map of Fort Apache Indian Reservation, Arizona, plate 2, in Moore, R.T., Mineral deposits of the Fort Apache Indian Reservation, Arizona: Tucson, Arizona Bureau of Mines, Bulletin 177, 84 p. (out of print).

Moore, R.T., and Wilson, E.D., 1962, Geologic cross sections of Arizona: Tucson, Arizona Bureau of Mines Report M-7-2, Sheet 2, sections 4, 5, 6.

Moore, R.T., Wilson, E.D., and O'Haire, R.T., 1960, Geologic map of Coconino County, Arizona: Tucson, Arizona, Arizona Bureau of Mines Map M-3-2, 1 sheet, scale 1:375,000.

Murray, C.R., and Reeves, E.B., 1972, Estimated use of water in the United States in 1970: U.S. Geological Survey Circular 676, 37 p.

Orr, B.R., 1987, Water resources of the Zuni tribal lands, McKinley and Cibola Counties, New Mexico: U.S. Geological Survey Water-Supply Paper 2227, 76 p.

O’Sullivan, R.B., and Beikman, H.M., compilers, 1963, Geology, structure, and uranium deposits of the Shiprock quadrangle, New Mexico and Arizona: U.S. Geological Survey Miscellaneous Investigations Map I-345, 2 sheets, scale 1:250,000. 
Owen-Joyce, S.J., and Bell, C.K., 1983, Appraisal of water resources in the upper Verde River area, Yavapai and Coconino Counties, Arizona: Phoenix, Arizona Department of Water Resources Bulletin 2, 219 p.

Parker, J.W., and Roberts, J.W., 1966, Regional Devonian and Mississippian stratigraphy, central Colorado Plateau: Bulletin of the American Associates of Petroleum Geologists, v. 50, no. 11, p. 2404-2433.

Peirce, H.W., 1964, Internal correlation of the Permian De Chelly Sandstone, Defiance Plateau, Arizona, in Contributions to the geology of northern ArizonaMajor Brady Memorial: Flagstaff, Arizona, Museum of Northern Arizona Bulletin 40, p. 15-32.

1967, Geologic guidebook 2-Highways of Arizona, Arizona Highways 77 and 177: Arizona Bureau of Mines Bulletin 176, 73 p.

Peirce, H.W., and Scurlock, J.R., 1972, Arizona well information: Tucson, Arizona Bureau of Mines Bulletin $185,195 \mathrm{p}$.

Peterson, Fred, 1988, Stratigraphy and nomenclature of middle and upper Jurassic rocks, Western Colorado Plateau, Utah and Arizona, in Revisions to Stratigraphic Nomenclature of Jurassic and Cretaceous Rocks of the Colorado Plateau: U.S. Geological Survey Bulletin 1633-B, p. 13-56.

Pope, G.L., Rigas, P.D., and Smith, C.F., 1998, Statistical summaries of streamflow data and characteristics of drainage basins for selected streamflow-gaging stations in Arizona through water year 1996, U.S. Geological Survey Water- Resources Investigations Report 98-4225, $907 \mathrm{p}$.

Reynolds, S.J., 1988, Geologic map of Arizona: Tucson, Arizona Geological Survey Map M-26, 1 sheet, scale 1:1,000,000.

Ross, P.P., 1977, Map showing ground-water conditions in the lower Verde River area, Maricopa, Yavapai, and Gila Counties, Arizona, 1976: U.S. Geological Survey Water-Resources Investigations Report 77-113, 1 sheet.

Rote, J.J., Flynn, M.E., Bills, D.J., 1997, Hydrologic data, Colorado River and major tributaries, Glen Canyon Dam to Diamond Creek, Arizona, water years 1990-95: U.S. Geological Survey, Open-File Report 97-250, $474 \mathrm{p}$.

Schruben, P.G., Arndt, R.E., Bawiec, W.J., and Ambroziak, R.A., 1994, Geology of the conterminous United States at 1:2,500,000 scale-A digital representation of the 1974 P.B. King and H.M. Beikman map: U.S. Geological Survey Digital Data Series DDS-11, 1 CD-ROM.

Sellers, W.D, and Hill, R.H., 1974, Arizona climate 19311972: Tucson, Arizona, University of Arizona Press, $616 \mathrm{p}$.
Sellers, W.D., Hill, R.H., and Sanderson-Rae, Margaret, eds., 1985, Arizona climate-The first hundred years: Tucson, Arizona, University of Arizona Press, $80 \mathrm{p}$.

Shoemaker, E.M., Squires, R.L., and Abrams, M.J., 1978, Bright Angel and Mesa Butte Fault systems of northern Arizona: Geological Society of America Memoir 152, 341-367 p.

Skibitzke, H.E., and Bowen, R.A., 1983, Model of the ground-water system near Coronado Generating Station in southern Apache County, Arizona: Phoenix, Arizona, Salt River Project report, 54 p.

Solley, W.B., Chase, E.B., and Mann, W.B., IV, 1983, Estimated use of water in the United States in 1980: U.S. Geological Survey Circular 1001, 56 p.

Solley, W.B., Merk, C.F., and Pierce, R.R., 1988, Estimated use of water in the United States in 1985: U.S. Geological Survey Circular 1004, 82 p.

Solley, W.B., Pierce, R.R., and Perlman, H.A., 1993, Estimated use of water in the United States in 1990: U.S. Geological Survey Circular 1081, 76 p.

Stetson, T.M., 1966, Feasibility of obtaining a ground water supply from Black Mesa, Arizona: Los Angeles, California, Thomas M. Stetson Civil and Consulting Engineers, $28 \mathrm{p}$.

Tadayon, Saeid, Duet, N.R., Fisk, G.G., McCormack, H.F., Pope, G.L., and Rigas, P.D., 1997, Water resources data Arizona water year 1997: U.S. Geological Survey Water-Data Report AZ-97-1, 416 p.

Twenter, F.R., and Metzger, D.G., 1963, Geology and ground water in Verde Valley-The Mogollon Rim region, Arizona: U.S. Geological Survey Bulletin 1177, 132 p.

Turner, S.F., and Feth, J.H., 1952, Notes on springs along the Mogollon Rim, Arizona: U.S. Geological Survey OpenFile Report 52-159, 16 p.

Ulrich, G.E., Billingsley, G.H., Hereford, Richard, Wolfe, E.W., Nealey, L.D., and Sutton, R.L., 1984, Map showing geology, structure, and uranium deposits of the Flagstaff, $1^{\circ}$ × $2^{\circ}$ quadrangle, Arizona: U.S. Geological Survey Miscellaneous Investigations Series Map I-1446, scale 1:250,000.

U.S. Department of Agriculture, 1981, Little Colorado River Basin, Arizona-New Mexico: Washington, D.C., U.S. Department of Agriculture, Soil Conservation Service, Economic Research Service, and the Forest Service, Summary Report and Appendices I-IV.

White, N.D., 1954, A study of perennial base flow in major south-flowing streams in Mogollon Rim region, in Feth, J.H., Preliminary report of investigations of springs in the Mogollon Rim Region, Arizona: U.S. Geological Survey unnumbered open-file report, $77 \mathrm{p}$.

White, N.D., Stulik, R.S., and Morse, E.K., 1963, Annual report on ground water in Arizona, spring 1962 to spring 1963: Phoenix, Arizona State Land Department Report 15, 136 p. 
Wilson, E.D., Moore, R.T., and O’Haire, R.T., 1958, Geologic map of Yavapai County: Tucson, Arizona, Arizona Bureau of Mines, Map Report M-3-10, 1 sheet, scale 1:375,000.

1959, Geologic map of Gila County: Tucson, Arizona, Arizona Bureau of Mines Map Report M-3-3, 1 sheet, scale 1:375,000.

1960, Geologic map of Navajo and Apache Counties, Arizona: Tucson, Arizona, Arizona Bureau of Mines Report M-3-7, 1 sheet.
Wilson, R.P., 1990, Arizona water supply and use, in Carr, J.E., Chase, E.B., Paulson, R.W., and Moody, D.W., compilers, National Water Summary 1987Hydrologic Events and Water Supply and Use: U.S. Geological Survey Water-Supply Paper 2350, p. 157164.

Wirt, Laurie, Van Metre, P.C., and Favor, Barbara, 1991, Historical water-quality data, Puerco River Basin, Arizona and New Mexico: U.S. Geological Survey Open-File Report 91-196, 339 p. 


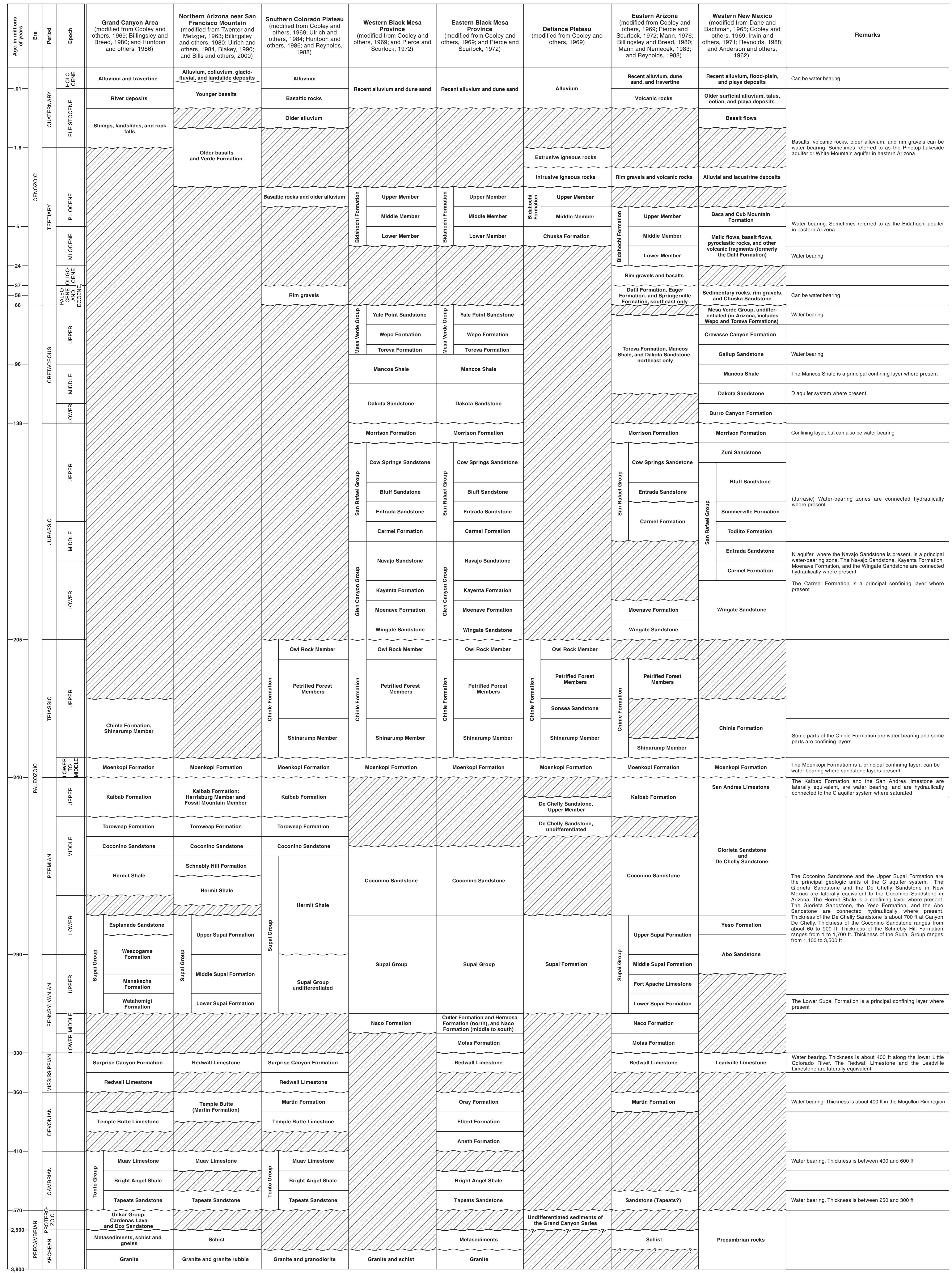

STRATIGRAPHIC CORRELATION OF ROCK UNITS IN THE LITTLE COLORADO RIVER BASIN, ARIZONA AND NEW MEXICO

Robert J. Hart, John J. Ward, Donald J. Bills, and Marilyn E. Flynn 